\title{
AVALIAÇÃO DA RESPOSTA TECIDUAL FRENTE AOS CIMENTOS MTA E MBPC. ANÁLISE MICROSCÓPICA DE IMPLANTES REALIZADOS EM ALVÉOLOS DENTÁRIOS DE RATOS.
}

\section{LUCIANO TAVARES ANGELO CINTRA}

Dissertação apresentada à Faculdade de Odontologia de Bauru, da Universidade de São Paulo, como parte dos requisitos para a obtenção do título de Mestre em Odontologia, área de Endodontia.

BAURU

2005 


\title{
AVALIAÇÃO DA RESPOSTA TECIDUAL FRENTE AOS CIMENTOS MTA E MBPC. ANÁLISE MICROSCÓPICA DE IMPLANTES REALIZADOS EM ALVÉOLOS DENTÁRIOS DE RATOS
}

\section{LUCIANO TAVARES ANGELO CINTRA}

\begin{abstract}
Dissertação apresentada à Faculdade de Odontologia de Bauru, da Universidade de São Paulo, como parte dos requisitos para a obtenção do título de Mestre em Odontologia, área de Endodontia.
\end{abstract}

Orientador: Prof. Dr. Ivaldo Gomes de Moraes Co-orientador: Pedro Felício Estrada Bernabé

BAURU

2005 


\begin{tabular}{|c|}
\hline Cintra, Luciano Tavares Angelo \\
Avaliação da resposta tecidual frente aos cimentos \\
MTA e MBPc. Análise microscópica de implantes \\
realizados em alvéolos dentários de ratos / Luciano \\
Tavares Angelo Cintra. - - Bauru, 2005. \\
191 p. : il. ; 30cm. \\
Dissertação. (Mestrado) - - Faculdade de \\
Odontologia de Bauru. USP. \\
Orientador: Prof. Dr. Ivaldo Gomes de Moraes
\end{tabular}

Autorizo, exclusivamente para fins acadêmico e científico, a reprodução total ou parcial desta dissertação, por processos fotocopiadores e outros meios eletrônicos.

Bauru, 24 de janeiro de 2005.

Projeto de Pesquisa aprovado pelo Comitê de Ética no Ensino e Pesquisa em Animais da Faculdade de Odontologia de Bauru - Universidade de São Paulo na reunião do dia 07 de maio de 2003 (CEEPA - Processo $n^{\circ}$ 012/2003). 


\section{Ficha Técnica}

Luciano Tavares Angelo Cintra: concepção, experimentos, análise microscópica, redação, digitação, ilustração, fotografia, tratamento de imagens, digitalização, formatação e análise estatística;

Ivaldo Gomes de Moraes: concepção original, orientação geral e revisão final;

Pedro Felício Estrada Bernabé: concepção original, orientação geral, colaboração nos experimentos e revisão final;

Tetuo Okamoto: orientação na metodologia, colaboração nos experimentos e análise microscópica;

Roberto Holland: orientação na metodologia e análise microscópica;

João Eduardo Gomes Filho: colaboração nos experimentos e revisão do inglês;

Tiago Novaes Pinheiro: análise microscópica e fotografia;

Mariana Machado Teixeira de Moraes Costa: colaboração nos experimentos;

Marianne di Paula Oliveira Peres: colaboração nos experimentos;

Neuza Angélica dos Santos: colaboração nos experimentos;

Neuci Vieira: processamento laboratorial;

Hermelinda de Jesus Pereira Brefore: processamento laboratorial;

Luciano Tavares Angelo Cintra: serviços gráficos; 


\section{Dados curriculares}

\section{Luciano Tavares Angelo Cintra}

Nascimento

Filiação

$1997-2000$

2001-2002

2003-2004

Associações
16 de setembro de 1978

Araçatuba - SP

Barcelo Angelo Cintra

Celeste Tavares Angelo Cintra

Curso de Graduação em Odontologia, na Faculdade de Odontologia de Araçatuba, Universidade Estadual Paulista "Júlio de Mesquita Filho", SP.

Curso de Especialização em Endodontia, na Faculdade de Odontologia de Araçatuba, Universidade Estadual Paulista "Júlio de Mesquita Filho", SP.

Curso de Mestrado em Odontologia, área de Endodontia pela Faculdade de Odontologia de Bauru, Universidade de São Paulo.

Associação Brasileira de Odontologia

Associação Paulista de Cirurgiões Dentistas

Sociedade Brasileira de Pesquisas Odontológicas

Associação Internacional de Pesquisas Odontológicas 


\section{Dedico este trabalho.}

A quem me guia, me ilumina e me inspira,

\section{Meu Pai maior, Deus;}

A quem me ensinou a viver,

\section{Meus Pais, Barcelo e Celeste;}

Se um dia, homem feito e realizado, sentir que a terra cede aos meus pés, que minhas obras desmoronaram, que não há mais ninguém a minha volta para me estender à mão, esquecerei a maturidade, passarei pela mocidade, voltarei à infância e balbuciarei entre lágrimas e esperanças as últimas palavras que restam na alma...

...minha mãe, meu pai...

(Modificado de Rui Barbosa) 
A quem demonstrou que a amizade, o companheirismo e a união são virtudes deste mundo,

\section{Meus irmãos, Licio e Leticia;}

A quem sempre esteve presente na realização deste trabalho,

\section{Meu irmão, Lúcio (in memorian);}

A quem me fez acreditar que o amor existe,

Minha Companheira, Milena;

A quem me dá sentido à vida,

\section{Meu Filho, Luan.}

Dedico o que, um dia, foi o meu sonho.

"Nunca se afaste de seus sonhos, pois se eles se forem, você continuará vivendo, mas terá deixado de existir".

Charles Chaplin 


\section{Tempo de oração}

Que Deus não permita que eu perca o ROMANTISMO, mesmo sabendo que as rosas não falam...

Que eu não perca o OTIMISMO, mesmo sabendo que o futuro que nos espera pode não ser tão alegre...

Que eu não perca a VONTADE DE VIVER, mesmo sabendo que a vida é, em muitos momentos, dolorosa...

Que eu não perca a vontade de TER GRANDES AMIGOS, mesmo sabendo que, com as voltas do mundo, eles acabam indo embora de nossas vidas...

Que eu não perca a vontade de AJUDAR AS PESSOAS, mesmo sabendo que muitas delas são incapazes de ver, reconhecer $e$ retribuir, esta ajuda...

Que eu não perca O EQUILÍBRIO, mesmo sabendo que inúmeras forças querem que eu caia...

Que eu não perca a VONTADE DE AMAR, mesmo sabendo que a pessoa que eu mais amo pode não sentir o mesmo sentimento por $\operatorname{mim} .$.

Que eu não perca a LUZE O BRILHO NO OLHAR, mesmo sabendo que muitas coisas que verei no mundo escurecerão meus olhos...

Que eu não perca a GARRA, mesmo sabendo que a derrota e a perda são dois adversários extremamente perigosos...

Que eu não perca a RAZÃO, mesmo sabendo que as tentações da vida são inúmeras e deliciosas... 
Que eu não perca o SENTIMENTO DE JUSTIÇA, mesmo sabendo que o prejudicado possa ser eu...

Que eu não perca o meu FORTE ABRAÇO, mesmo sabendo que um dia meus braços estarão fracos...

Que eu não perca a BELEZA E A ALEGRIA DE VER, mesmo sabendo que muitas lágrimas brotarão dos meus olhos $e$ escorrerão por minha alma...

Que eu não perca o AMOR POR MINHA FAMÍLIA, mesmo sabendo que ela muitas vezes me exigiria esforços incríveis para manter a sua harmonia...

Que eu não perca a vontade de DOAR ESTE ENORME AMOR que existe em meu coração, mesmo sabendo que muitas vezes ele será submetido e até rejeitado...

Que eu não perca a vontade de SER GRANDE, mesmo sabendo que o mundo é pequeno...

E acima de tudo...

Que eu jamais me esqueça que Deus me ama infinitamente!

Que um pequeno grão de alegria e esperança dentro de cada um é capaz de mudar e transformar qualquer coisa, pois...

a VIDA É CONSTRUÍdA NOS SONHOS E CONCRETIZADA NO AMOR!

Francisco Cândido Xavier 


\section{Agradecimentos}

Ao meu Orientador,

Prof. Dr. Ivaldo Gomes de Moraes

e ao meu Co-Orientador,

Prof. Dr. Pedro Felício Estrada Bernabé

Que me ensinaram a amar a odontologia, a pesquisa e o ensino. Agradeço pela participação decisiva para que eu me tornasse um Mestre, pelo exemplo, pelo incentivo, pela confiança, pela amizade e agora pela vitória.

Divido com vocês, meus pais, a alegria deste momento. 


\section{Agradeço especialmente}

Aos professores da Disciplina de Endodontia, da faculdade de Odontologia de Bauru - USP, pelo exemplo, ensinamentos valiosos, dedicação e atenção: Prof. Clovis Monteiro Bramante, Roberto Brandão Garcia, Norberti Bernardineli e mais uma vez ao meu orientador Ivaldo Gomes de Moraes.

Ao Prof. Roberto Holland pela amizade e pelo incentivo na realização deste trabalho.

Ao Prof. Tetuo Okamoto, por permitir participar de sua experiência, conhecimentos e sabedoria.

Aos professores da Disciplina de Endodontia, da faculdade de Odontologia de Araçatuba - UNESP, pelo incentivo, pela determinação e pela atenção: Prof. Valdir de Souza, Mauro Juvenal Nery, José Arlindo Otoboni Filho, Eloi Dezan Júnior, João Eduardo Gomes Filho e mais uma vez ao meu querido amigo Pedro Felício Estrada Bernabé.

Aos funcionários da Disciplina de Endodontia da Faculdade de Odontologia de Araçatuba - UNESP, e da Faculdade de Odontologia de Bauru - USP, pela paciência, assistência e prontidão: Nelci, Hermelinda, Neuza, Alexandrina, Edimauro, Suely, Neide e Patrícia.

Aos funcionários da Biblioteca pelo profissionalismo.

Aos colegas do curso de Mestrado, pela amizade, companheirismo e colaboração: Adriana, Amélio, Augusto, Eduardo, Daniele, Fabiano, Járcio, Norberto, Thais e Tiago.

A todos aqueles que direta ou indiretamente contribuíram para a realização deste trabalho. 


\section{Agradecimentos institucionais}

A Faculdade de Odontologia de Bauru, Universidade de São Paulo, na pessoa da Diretora, Professora Maria Fidela de Lima Navarro e em especial à Disciplina de Endodontia desta Faculdade;

A Comissão de Pós-Graduação da Faculdade de Odontologia de Bauru, na pessoa do Presidente, Professor José Carlos Pereira;

A Faculdade de Odontologia de Araçatuba, Universidade Estadual Paulista, na pessoa do Diretor, Professor Paulo Roberto Botacin, e em especial à Disciplina de Endodontia desta Faculdade por auxiliar em toda parte experimental deste trabalho;

A CAPES, pelo apoio integral a esta pesquisa com seu auxílio financeiro e logístico. 


\section{SUMÁRIO}

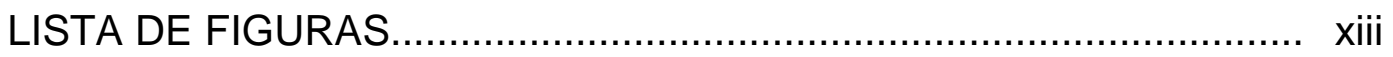

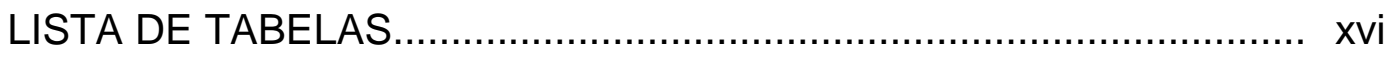

LISTA DE ABREVIATURAS E SÍMBOLOS.............................. xix

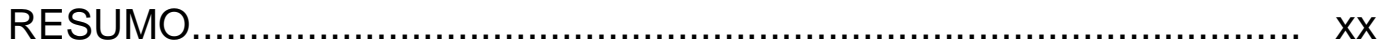

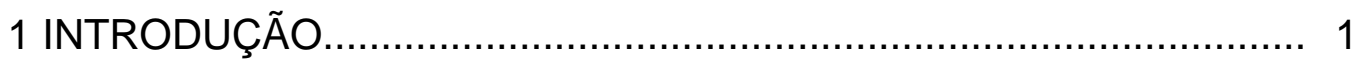

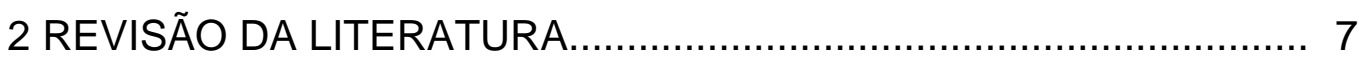

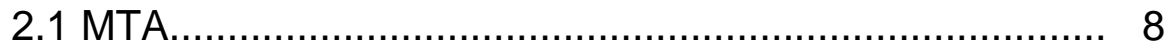

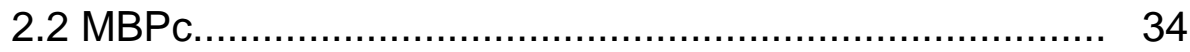

3 PROPOSIÇÃO................................................................. 38

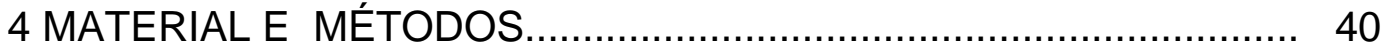

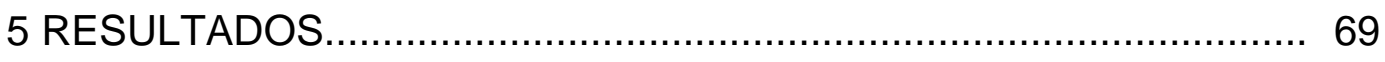

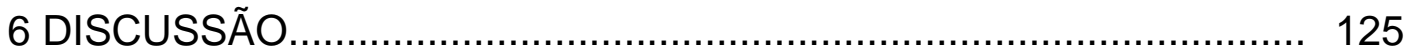

6.1 Da concepção do trabalho.................................. 126

6.2 Dos materiais empregados................................ 128

6.3 Da metodologia empregada................................. 131

6.4 Dos resultados obtidos...................................... 136

6.5 Aplicações clínico-terapêuticas e perspectivas..................... 141

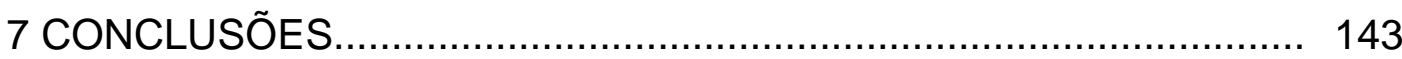

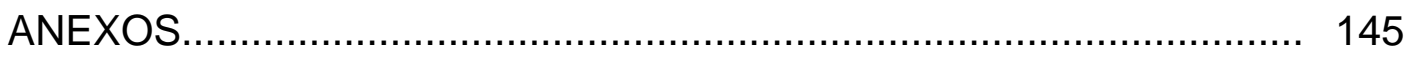

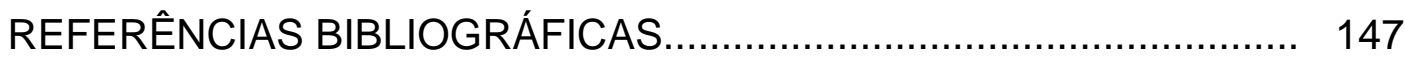

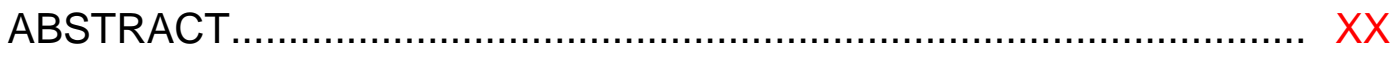




\section{LISTA DE FIGURAS}

Figura 1 - Cimento reparador ProRoot MTA (Dentsply - Tulsa Dental).

Figura 2 - Cimento experimental MBPc (Faculdade de Odontologia de Bauru - Universidade de São Paulo)..

Figura 3 - Tubo de polietileno (Abbott Lab. do Brasil Ltda., São Paulo, SP ).

Figura 4 - Anestésico Vetanarcol (König S. A. - Avellaneda, Argentina) e sedativo Dopaser (Calier S.A. Barcelona, Espanha).

Figura 5 - Luxação do alvéolo

Figura 6 - Extração do incisivo superior direito

Figura 7 - Implantação do tubo de polietileno.

Figura 8 - Introdução do tubo de polietileno.

Figura 9 - Separação da maxila da mandíbula

Figura 10 - Separação das maxilas.

Figura 11 - Obtenção da hemi-maxila direita

Figura 12 - Hemi-maxila direita.

Figura 13 - Hemi-maxila direita sob visão lateral.

Figura 14 - Aspecto lateral do crânio.

Figura 15 - Corte sagital mediano do crânio

Figura 16 - Hemi-maxila direita sob visão lateral

Figura 17 - Corte longitudinal do alvéolo.

Figura 18 - Desenho esquemático do corte tecidual.

Figura 19 - Aspecto radiográfico dorsal da cabeça do rato.

Figura 20 - Representação esquemática dos escores atribuídos ao infiltrado inflamatório.

Figura 21 - Representação esquemática dos escores atribuídos à presença e à localização da deposição de tecido mineralizado. 
Figura 22 - Representação esquemática dos escores atribuídos à presença e à localização da deposição de tecido ósseo

Figura 23 - Aspecto microscópico do implante de tubo de polietileno vazio em alvéolo dentário de rato observado em cortes longitudinais corados com H. E., após 7 dias. Destacam-se a presença de discreto infiltrado inflamatório no tecido conjuntivo subjacente, tecido conjuntivo invaginado para o interior do tubo e restos de tecido odontogênico interpostos entre a resposta inflamatória ao tubo e o fundo do alvéolo......

Figura 24- Aspecto microscópico do implante de tubo de polietileno com ProRoot MTA em alvéolo dentário de rato observado em cortes longitudinais corados com H. E., após 7 dias. Destacam-se a presença de faixa irregular com necrose por coagulação junto ao material e de discreto infiltrado inflamatório no tecido conjuntivo subjacente.

Figura 25 - Aspecto microscópico do implante de tubo de polietileno com MBPc em alvéolo dentário de rato observado em cortes longitudinais corados em H. E., após 7 dias. Destacam-se a presença de faixa hialina em contato com o material e de áreas basofílicas, subjacente. $O$ tecido de granulação apresenta-se com discreto infiltrado inflamatório composto, predominantemente por macrófagos e linfócitos...........

Figura 26 - Aspecto microscópico do implante de tubo de polietileno vazio em alvéolo dentário de rato observado em cortes longitudinais corados em H. E., após 15 dias. Destacam-se a presença de discreto infiltrado inflamatório no tecido conjuntivo subjacente, tecido capsular invaginado no interior do tubo 
composto, predominantemente, por fibroblastos jovens, vasos sanguíneo, células inflamatórias e reparo ósseo junto ao fundo alveolar

Figura 27 - Aspecto microscópico do implante de tubo de polietileno com ProRoot MTA em alvéolo dentário de rato observado em cortes longitudinais corados em $\mathrm{H}$. E., após 15 dias. Destaca-se, junto ao material, a presença de material eosinofílico amorfo justaposto a áreas basofílicas irregulares. Observa-se, ainda, a presença de discreto infiltrado inflamatório junto ao tecido conjuntivo subjacente.

Figura 28 - Aspecto microscópico do implante de tubo de polietileno com MBPc em alvéolo dentário de rato observado em cortes longitudinais corados em H. E., após 15 dias. Destacam-se a presença de discreto infiltrado inflamatório, no tecido conjuntivo subjacente e tecido capsular bem organizado. Observa-se, também, a presença de faixa hialina em contato com o material e de áreas basofílicas, subjacente

Figura 29 - Aspecto microscópico do implante de tubo de polietileno vazio em alvéolo dentário de rato observado em cortes longitudinais corados em H. E., após 30 dias. Destacam-se a presença de discreto infiltrado inflamatório no tecido conjuntivo subjacente, tecido capsular bem organizado, junto ao tubo, e reparo ósseo próximo ao fundo alveolar.

Figura 30 - Aspecto microscópico do implante de tubo de polietileno com ProRoot MTA em alvéolo dentário de rato observado em cortes longitudinais corados em $\mathrm{H}$. E., após 30 dias. Destacam-se a presença de discreto infiltrado inflamatório no tecido conjuntivo e intensa neoformação óssea. Observa-se, também, a 
presença de tecido mineralizado depositado junto ao material.

Figura 31 - Aspecto microscópico do implante de tubo de polietileno com MBPc em alvéolo dentário de rato observado em cortes longitudinais corados em H. E., após 30 dias. Destaca-se a presença de delgada faixa de tecido conjuntivo densamente organizado em contato direto com o material. Nota-se, ainda, a ausência de infiltrado inflamatório junto ao tecido conjuntivo e a neoformação óssea em proximidade com o material.

Figura 32 - Gráfico representativo das médias dos escores atribuídos ao infiltrado inflamatório de acordo com os períodos de observação

Figura 33 - Gráfico representativo das médias dos escores atribuídos a densidade de fibroblastos jovens de acordo com os períodos de observação.

Figura 34 - Gráfico representativo das médias dos escores atribuídos a densidade angioblástica de acordo com os períodos de observação.

Figura 35 - Gráfico representativo das médias dos escores atribuídos a densidade do fibrosamento de acordo com os períodos de observação

Figura 36- Gráfico representativo das médias dos escores atribuídos a presença e localização da deposição de tecido mineralizado de acordo com os períodos de observação

Figura 37 - Gráfico representativo das médias dos escores atribuídos a presença e localização da deposição de tecido ósseo de acordo com os períodos de observação 


\section{LISTA DE TABELAS}

Tabela 1 - Composição do cimento ProRoot MTA.

Tabela 2 - Composição do cimento MBPc.

Tabela 3 - Distribuição dos materiais retrobturadores em grupos experimentais por períodos e número de espécimes.

Tabela 4 - Tabela utilizada para a distribuição dos dados presentes nos grupos experimentais por períodos e número de espécimes

Tabela 5 - Tabela utilizada para a distribuição dos escores atribuídos aos grupos experimentais de acordo com os critérios estabelecidos, separados por períodos e número de espécimes.

Tabela 6 - Grupo Controle - 7 dias - Descrição atribuída aos eventos microscópicos observados nos espécimes analisados

Tabela 7 - Grupo ProRoot MTA - 7 dias - Descrição atribuída aos eventos microscópicos observados nos espécimes analisados

Tabela 8 - Grupo MBPc - 7 dias - Descrição atribuída aos eventos microscópicos observados nos espécimes analisados......

Tabela 9 - Grupo Controle - 15 dias - Descrição atribuída aos eventos microscópicos observados nos espécimes analisados

Tabela 10 - Grupo ProRoot MTA - 15 dias - Descrição atribuída aos eventos microscópicos observados nos espécimes analisados

Tabela 11 - Grupo MBPc - 15 dias - Descrição atribuída aos eventos microscópicos observados nos espécimes analisados......

Tabela 12 - Grupo Controle - 30 dias - Descrição atribuída aos eventos microscópicos observados nos espécimes 
analisados

Tabela 13 - Grupo ProRoot MTA - 30 dias - Descrição atribuída aos eventos microscópicos observados nos espécimes analisados

Tabela 14 - Grupo MBPc - 30 dias - Descrição atribuída aos eventos microscópicos observados nos espécimes analisados......

Tabela 15 - Critério infiltrado inflamatório - 7 dias - Escores atribuídos aos eventos microscópicos observados nos espécimes analisados

Tabela 16 - Critério infiltrado inflamatório - 15 dias - Escores atribuídos aos eventos microscópicos observados nos espécimes analisados

Tabela 17 - Critério infiltrado inflamatório - 30 dias - Escores atribuídos aos eventos microscópicos observados nos espécimes analisados

Tabela 18 - Critério densidade de fibroblastos jovens - 7 dias Escores atribuídos aos eventos microscópicos observados nos espécimes analisados.

Tabela 19 - Critério densidade de fibroblastos jovens - 15 dias Escores atribuídos aos eventos microscópicos observados nos espécimes analisados.

Tabela 20 - Critério densidade de fibroblastos jovens -30 dias Escores atribuídos aos eventos microscópicos observados nos espécimes analisados.

Tabela 21 - Critério densidade angioblástica - 7 dias - Escores atribuídos aos eventos microscópicos observados nos espécimes analisados

Tabela 22 - Critério densidade angioblástica - 15 dias - Escores atribuídos aos eventos microscópicos observados nos espécimes analisados

Tabela 23 - Critério densidade angioblástica -30 dias - Escores atribuídos aos eventos microscópicos observados nos 
espécimes analisados.

Tabela 24 - Critério densidade do fibrosamento - 7 dias - Escores atribuídos aos eventos microscópicos observados nos espécimes analisados

Tabela 25 - Critério densidade do fibrosamento - 15 dias - Escores atribuídos aos eventos microscópicos observados nos espécimes analisados

Tabela 26 - Critério densidade do fibrosamento -30 dias - Escores atribuídos aos eventos microscópicos observados nos espécimes analisados

Tabela 27 - Critério tecido mineralizado - 7 dias - Escores atribuídos aos eventos microscópicos observados nos espécimes analisados

Tabela 28 - Critério tecido mineralizado - 15 dias - Escores atribuídos aos eventos microscópicos observados nos espécimes analisados

Tabela 29 - Critério tecido mineralizado - 30 dias - Escores atribuídos aos eventos microscópicos observados nos espécimes analisados

Tabela 30 - Critério tecido ósseo - 7 dias - Escores atribuídos aos eventos microscópicos observados nos espécimes analisados

Tabela 31 - Critério tecido ósseo - 15 dias - Escores atribuídos aos eventos microscópicos observados nos espécimes analisados

Tabela 32 - Critério tecido ósseo - 30 dias - Escores atribuídos aos eventos microscópicos observados nos espécimes analisados

Tabela 33 - Critérios de classificação dos níveis de concordância de coeficiente Kappa.

Tabela 34 - Coeficiente de concordância (Kappa) para os fenômenos inflamatório e reparatório nos três períodos analisados..... 
Tabela 35 - Teste de Kruskal-Wallis para análise do resultado geral entre os 3 grupos (experimentais e controle) no período de 7 dias

Tabela 36 - Teste de Kruskal-Wallis para análise do resultado geral entre os 3 grupos (experimentais e controle) no período de 15 dias

Tabela 37 - Teste de Kruskal-Wallis para análise do resultado geral entre os 3 grupos (experimentais e controle) no período de 30 dias

Tabela 38 - Teste de Kruskal-Wallis para análise do resultado entre os 3 grupos (experimentais e controle) no período de 7 , 15 e 30 dias, para cada um dos 5 critérios de análise microscópica

Tabela 39 - Teste de Dunn para comparações individuais entre os 3 grupos quanto ao critério densidade de fibroblastos jovens no período de 30 dias

Tabela 40 - Teste de Dunn para comparações individuais entre os 3 grupos quanto ao critério presença e localização da deposição do tecido ósseo no período de 7 dias

Tabela 41 - Teste $U$ de Mann-Whitney para análise do resultado geral entre os grupos MTA E MBPc no período de 7 dias

Tabela 42 - Teste $U$ de Mann-Whitney para análise do resultado geral entre os grupos MTA E MBPC no período de 15 dias.

Tabela 43 - Teste U de Mann-Whitney para análise do resultado geral entre os grupos MTA E MBPC no período de 30 dias.

Tabela 44 - Teste U de Mann-Whitney para análise comparativa do resultado entre o MTA e o MBPc 7, 15 e 30 dias, para cada um dos 6 critérios da análise microscópica 


\section{LISTA DE ABREVIATURAS E SÍMBOLOS}

$\cong$ aproximadamente

$\%$ por cento

${ }^{\circ} \mathbf{C}$ graus Celsius

$\mu \mathrm{m}$ micrometros

EDTA ácido etilenodiaminotetracético

FDA Food and Drugs Administration

Ind indústria

IRM material restaurador temporário

Ltda limitada

MBP Moraes / Berbert pasta

MBPc Moraes / Berbert pasta cirurgia

MBLc Moraes / Berbert líquido cirurgia

MEV microscópio eletrônico de varredura

mg miligramas

mm milímetros

MSD material safety data sheet

MTA agregado de trióxidos minerais

OZE óxido de zinco e eugenol

PVPI polivinilpirrolidona-iodado

UNESP Universidade Estadual Paulista

USA Estados Unidos da América

USP Universidade de São Paulo 


\section{RESUMO}

Este trabalho teve como objetivo avaliar quantitativa e qualitativamente a resposta inflamatória e a formação óssea frente ao implante de tubos de polietileno contendo o cimento experimental, MBPc, que contém o hidróxido de cálcio, desenvolvido pelos Profs. MORAES e BERBERT da disciplina de Endodontia da Faculdade de Odontologia de Bauru - USP, comparando-o ao cimento ProRoot MTA. Foram utilizados 48 ratos, divididos em três grupos. No grupo I, foram introduzidos no alvéolo dentário pós-extração tubos de polietileno vazios que serviram de controle para os grupos experimentais. No grupo II foram implantados tubos contendo o cimento ProRoot MTA e no grupo III o cimento experimental MBPc. Após 7, 15 e 30 dias do implante os animais foram mortos e as hemimaxilas direitas que continham os alvéolos e os tubos implantados foram removidas e processadas em laboratório para a análise em microscopia de luz. Os resultados demonstraram que ambos materiais têm comportamento biológico semelhante. Os valores obtidos por meio da avaliação por escores, quando submetidos ao teste de Mann-Whitney, cujo nível de significância adotado foi de 5\%, não apresentaram diferenças estatisticamente significante entre os materiais. 


\section{INTRODUÇÃO}




\section{INTRODUÇÃO}

A finalidade do tratamento endodôntico é neutralizar e remover todo o conteúdo necrótico e tóxico do sistema de canais radiculares por meio do preparo biomecânico e da colocação de um curativo de demora. O processo de preenchimento do espaço criado com a remoção do tecido pulpar e preparo biomecânico é chamado de obturação do sistema de canais radiculares, que tem por objetivo estabelecer uma barreira física, ou seja, ocupar o espaço vazio impedindo uma nova invasão e colonização bacteriana ou até impossibilitando que bactérias aprisionadas possam lesar os tecidos periapicais. Proporcionar condições para que o reparo ocorra e estimular a obturação biológica fecham os objetivos da obturação do sistema de canais radiculares. Estas três etapas compostas por preparo biomecânico, curativo de demora e obturação do sistema de canais radiculares denominam-se tratamento endodôntico convencional.

Com o avanço técnico e científico proporcionado por novos materiais, instrumentais e aparelhos endodônticos, permite-se a realização de uma endodontia de excelência que eleva, de certa maneira, o índice de sucesso dos tratamentos endodônticos convencionais. Em 1991, GUTMANN; HARRISON ${ }^{51}$ já relatavam um índice de sucesso ao redor de $90 \%$ e que hoje, após pouco mais de uma década, observa-se que tais índices aumentaram, em função da evolução da qualidade dos tratamentos endodônticos realizados. No entanto, é certo que uma pequena parcela dos tratamentos falham e que o número de tais falhas aumenta à medida que os profissionais não acompanham a evolução técnica e cientifica relacionada à endodontia.

Existem inúmeros fatores relacionados com os insucessos dos tratamentos endodônticos, porém sua maioria ocorre pela inobservância de uma de suas fases operatórias. Os fatores inerentes às dificuldades que ocorrem no momento da execução da técnica endodôntica merecem 
destaque, sobretudo na escolha de qual técnica será a mais adequada para aquele determinado caso. As perfurações radiculares e as fraturas de instrumentos conduzem o caso para um tratamento que não o convencional e colocam os clínicos em situações delicadas e a grande maioria não sabe como resolvê-las. Questões quanto à infiltração via coronária e apical também são relevantes nos insucessos endodônticos, assim como a anatomia dentária pela presença de calcificações ou aberrações anatômicas. Os procedimentos protéticos realizados após os procedimentos endodônticos normalmente não seguem um protocolo que assegura 0 sucesso do tratamento, e de alguma forma permitem a reinfecção apical.

Pois bem, a vitória dos microorganismos frente ao sistema imunológico representa o insucesso do tratamento endodôntico como um todo, que muitas vezes silencioso não é percebido pelos profissionais.

Nesses casos o tratamento convencional pode não resultar em um completo reparo da região atingida pela doença e a cirurgia parendodôntica deverá ser instituída, conscientes de que este será o último recurso a ser realizado com o intuito de se solucionar casos especiais em que o tratamento endodôntico convencional não logrou o resultado esperado (BERNABÉ $\left.^{10}, 1981\right)$.

Uma vez, o caso selecionado para a realização de um procedimento parendodôntico, surgem dúvidas sobre, qual técnica cirúrgica empregar ou qual material retrobturador utilizar. Frente aos conhecimentos obtidos, não se pode admitir a realização de um procedimento cirúrgico que não seja bem estabelecido e consolidado para aquele determinado caso. É de fundamental importância que as modalidades parendodônticas praticadas, e os materiais retrobturadores indicados, estejam também calcados em fundamentos biológicos, em métodos cientificamente explorados, não se admitindo, hoje, "às portas do século XXI", recorrer-se a métodos empíricos que, infelizmente, ainda contam com adeptos em nosso meio (MORANDI $\left.{ }^{87}, 1999\right)$. 
O índice de sucesso obtido em procedimentos parendodônticos nos anos 70 e relatados por HARTY; PARKINS; WEINGRAF ${ }^{54}$ e por RUD; ANDREASEN; JENSEN ${ }^{111}$ estava entre 50 e $70 \%$ e era realizado por meio de análises clínico-radiográficas que, com certeza, se tais casos fossem submetidos a uma análise mais rigorosa por meio da observação microscópica, por exemplo, esses índices seriam ainda menores.

A partir de 1975 novos estudos de caráter microscópico, realizados experimentalmente em animais, deram inúmeras razões para serem repensados os procedimentos cirúrgicos até então adotados (MARCOTTE; DOWSON; ROWE ${ }^{81}$, 1975, BERNABÉ ${ }^{10}$, 1981, MORANDI ${ }^{87}$, 1999). Podia-se observar anteriormente apenas estudos referentes à capacidade seladora dos materiais retrobturadores, ou experimentações de caráter clínico ou radiográfico.

Iniciou-se, então, uma busca de novas técnicas e de novos materiais a fim de satisfazer os critérios biológicos e colaborar com o processo de reparo dos tecidos periapicais.

A exemplo do tratamento endodôntico convencional, nas cirurgias parendodônticas o material retrobturador visa, também, promover o selamento hermético do conduto radicular. No entanto, é importante considerar a necessidade do emprego de materiais que sejam biocompatíveis, pois estarão definitivamente em contato com os tecidos periapicais. Quanto aos materiais retrobturadores que atendam às necessidades biológicas, o seu estudo, em dentes de cães portadores ou não de lesões periapicais, foi iniciado por BERNABÉ ${ }^{10}$, em 1981, analisando a reação tecidual dos tecidos periapicais após emprego do amálgama de prata e da guta-percha.

Outros trabalhos também foram realizados com o mesmo propósito, ou seja, a escolha de um material biocompatível, atóxico, que não provoque necrose tecidual e que seja rapidamente aceito pelos tecidos sem 
que mantenha uma seqüela inflamatória (GUTUSO ${ }^{52}, 1963$, BERNABÉ ${ }^{11}$, 1977, MORSE, D.R. et al. ${ }^{89}$, 1984, BERNABÉ ${ }^{12}$, 1994).

KUTTLER ${ }^{71}$, em 1980, havia ressaltado que a obturação dos canais radiculares deve carregar consigo, um estimulante biológico e isolante biocompatível. Sabe-se que alguns desses materiais podem, através de um mecanismo já conhecido, estimular a deposição de tecido mineralizado no ápice radicular resultando no chamado selamento biológico (HOLLAND $^{56}, 1971$, HOLLAND; SOUZA $\left.{ }^{65}, 1985\right)$.

Essa ocorrência em procedimentos cirúrgicos parendodônticos também foi demonstrada por BERNABÉ ${ }^{12}$ (1994), e por BERNABÉ; HOLLAND ${ }^{21}$ (1998), ou seja, o selamento biológico por meio da deposição de tecido duro sobre a superfície apicectomizada e material retrobturador.

Do que se depreende desses trabalhos, a participação ativa dos componentes integrantes da fórmula dos materiais retrobturadores, particularmente o hidróxido de cálcio, é de fundamental importância no processo de reparo dos tecidos periapicais.

Um dos materiais mais estudados na atualidade é cimento reparador ProRoot MTA desenvolvido por TORABINEJAD e sua equipe (TORABINEJAD; WATSON; PITT FORD ${ }^{147}$, 1993, LEE; MONSEF; TORABINEJAD ${ }^{78}$, 1993). Este material contém em sua fórmula o óxido de cálcio que quando em contato com a água ou fluido tecidual transforma-se em hidróxido de cálcio. Em 1994, PITT FORD; HONG; TORABINEJAD ${ }^{107}$, demonstraram a ocorrência de selamento biológico com o MTA em cirurgias parendodônticas em um trabalho realizado em dente de cães. Posteriormente, TORABINEJAD et al. ${ }^{142,145}$ (1995 - 1997), MORANDI ${ }^{87}$ (1999) e BERNABÉ et al. ${ }^{16}$ (2002), também demonstraram ser possível a ocorrência de selamento biológico quando o MTA era utilizado como material retrobturador. 
Apesar das excelentes propriedades biológicas que 0 cimento ProRoot MTA já demonstrou, outros materiais estão sendo desenvolvidos com o propósito de se manter ou melhorar ainda mais essas propriedades e que sejam materiais de fácil manipulação e aplicação.

O cimento endodôntico cirúrgico $\mathrm{MBPc}$, é um cimento experimental desenvolvido na disciplina de Endodontia da Faculdade de Odontologia de Bauru - USP, pelos professores Ivaldo Gomes de Moraes e Alceu Berbert, fruto de uma linha de pesquisa iniciada em 1984 $\left(\right.$ MORAES $\left.{ }^{86}\right)$.

À base de resina epóxica, contendo em sua fórmula o hidróxido de cálcio, este cimento, foi desenvolvido para ser utilizado em obturações retrógradas (PAVAN ${ }^{101}$, 1999) e perfurações radiculares (SILVA NETO; MORAES ${ }^{126}$, 2003) como componente obturador.

Até o presente momento, todos os trabalhos realizados com o cimento MBPc, avaliaram suas propriedades físico-químicas encontrando excelentes resultados (BRANDÃO ${ }^{26}$, 1999, PAVAN ${ }^{101}$, 1999, SILVA NETO; MORAES ${ }^{126}$, 2003), no entanto suas propriedades biológicas ainda não foram avaliadas. Tendo em vista que este material é carente de informações quanto às propriedades biológicas, motiva-nos a realização de uma experimentação que possibilite compará-las às do cimento ProRoot MTA, material este, já exaustivamente estudado como material retrobturador. 
2 REVISÃO DA LITERATURA 


\section{REVISÃO DA LITERATURA}

\subsection{MTA}

O Agregado de Trióxidos Minerais (MTA) surgiu no começo dos anos 90, como um material experimental que foi desenvolvido na Universidade de Loma Linda - Califórnia, Estados Unidos, pelo Prof. Mahmoud Torabinejad e sua equipe. Desenvolvido para ser utilizado como material selador de comunicações entre o interior e exterior do dente, o MTA ganhou aceitação internacional após inúmeros trabalhos que comprovaram sua efetividade.

Em 1993, LEE; MONSEF; TORABINEJAD ${ }^{78}$ publicaram o primeiro trabalho científico envolvendo o MTA. Nesta oportunidade os autores realizaram um estudo "in vitro" comparativo, avaliando a infiltração marginal em perfurações radiculares laterais de molares humanos empregando também o amálgama e o IRM. Os espécimes permaneceram por 48 horas em corante azul de metileno e, posteriormente, foram avaliados quanto à infiltração ocorrida entre a superfície dentinária e o material selador. Os dados encontrados demonstraram que o MTA apresentou os melhores resultados, por permitir os menores índices de infiltração marginal do corante, sendo os dados estatisticamente significantes.

Ainda em 1993, TORABINEJAD; WATSON; PITT FORD ${ }^{147}$ realizaram outro estudo "in vitro" comparando, agora, o MTA com o Super EBA. Foram utilizadas 34 raízes, padronizadas quanto ao comprimento, cujos canais foram instrumentados e obturados. Foi realizada a apicectomia em 3mm, o preparo cavitário e a retrobturação com os materiais em estudo. O controle negativo foi o selamento com cera pegajosa e o controle positivo sem selamento. O corante empregado neste experimento foi a rodamina B e a avaliação da infiltração marginal foi realizada utilizando-se da microscopia confocal. Corroborando com os dados da primeira investigação observou-se 
que com o emprego do MTA, os índices de infiltração foram menores que o grupo do Super EBA.

De acordo com LEE; MONSEF; TORABINEJAD ${ }^{78}$ (1993) o MTA apresenta-se como um pó de finas partículas hidrofílicas que, na presença de umidade, endurece e que, originariamente este material foi idealizado para ser empregado em casos de cirurgias parendodônticas como material retrobturador e em casos de perfurações radiculares ou de furca como material selador. Segundo TORABINEJAD; MacDONALD; PITT FORD $^{145}$ (1995) ele é um agregado trióxido mineral composto por óxido de cálcio, dióxido de silício, óxido férrico, óxido de alumínio, sulfato de cálcio, óxido de magnésio, óxidos de sódio e potássio, além da pequena quantidade de outros óxidos minerais e do óxido de bismuto responsável pela radiopacidade

TORABINEJAD et al. ${ }^{141}$, em 1994, avaliaram a quantidade de infiltração de corante, quando em presença ou não do sangue em retrocavidades preenchidas com amálgama de prata, Super EBA, IRM e MTA. Foram utilizados 90 dentes humanos extraídos, dos quais, foram removidas as coroas, os canais instrumentados e obturados. Uma vez impermeabilizados realizou-se a secção da porção apical em $2 \mathrm{~mm}$ e preparou-se retrocavidades em todos os dentes. O controle positivo foi realizado com guta-percha sem cimento e o negativo, impermeabilizou-se os dentes, com cera em bastão. Os demais espécimes foram divididos conforme os materiais empregados e em cada grupo metade dos dentes foi contaminada com sangue previamente à inserção do material. Após imersão em azul de metileno a 1\% durante 72 horas foi avaliada a infiltração do corante na interface dente e material retrobturador. Como resultado, os autores relataram que a presença de sangue não apresentou efeito significativo na infiltração do corante e que o MTA permitiu, significantemente, menor infiltração quando comparado com os demais materiais. 
Também em 1994, PITT FORD; HONG; TORABINEJAD ${ }^{107}$ realizaram um trabalho em dentes de cães, empregando o amálgama de prata e o MTA como materiais retrobturadores após apicectomia e preparo de retrocavidades. Após períodos de 10 a 18 semanas, os autores demonstraram que sobre o MTA havia formação de tecido duro assim como maior deposição de tecido ósseo adjacente a ele.

Em 1995, TORABINEJAD et al. ${ }^{143}$ também estudaram a resposta biológica dos tecidos periapicais de dentes de cães após apicectomia e obturação retrógrada com MTA ou amálgama. Após um período de 2 a 5 semanas ou 10 a 18 semanas os animais foram mortos e as peças processadas para exame microscópico. Os autores observaram que os tecidos periapicais de todas as raízes preenchidas com amálgama apresentavam inflamação de moderada para severa e apenas um terço das raízes com MTA apresentava inflamação moderada. O infiltrado inflamatório encontrado adjacente ao amálgama era predominantemente de PMN leucócitos enquanto que adjacente ao MTA eram linfócitos. Não foi encontrado nenhum tecido capsular fibroso sobre o amálgama. Já no grupo do MTA este quadro microscópico ocorreu em 19 dos 21 espécimes. Não foram observadas formações de cemento nos espécimes retrobturados com amálgama enquanto que no grupo do MTA houve formação de cemento em 1 das 11 amostras do período de 2 a 5 semanas e 10 das 10 amostras do período de 10 a 18 semanas. Os autores relataram que o cemento reparador era depositado tanto na dentina exposta pelo seccionamento apical, reparando áreas de reabsorção, como também sobre o material retrobturador em estudo.

Neste mesmo ano, TORABINEJAD et al. ${ }^{140}$ avaliaram a adaptação marginal do MTA quando empregado como material retrobturador, sob a microscopia de varredura, comparando-o ao amálgama, Super EBA e IRM. A distância entre os materiais retrobturadores e a superfície dentinária foi avaliada em quatro pontos distintos com os aumentos de 30X e 100X. A análise estatística dos valores obtidos 
demonstrou que o MTA foi o material de melhor adaptação marginal quando comparado aos outros materiais estudados.

Novamente TORABINEJAD et al. ${ }^{145}$, em 1995, realizaram estudos referentes às propriedades físicas e químicas do MTA. Quanto ao pH, o MTA possui valor de 10,2 logo após a hidratação com água destilada, e este valor sobe e estabiliza em 12,5 após 3 horas da mistura. Quanto à radiopacidade, o MTA é mais radiopaco que o IRM, Super-EBA e ligeiramente menos radiopaco que o Kalzinol. Quanto ao tempo de presa, relatou-se que o MTA leva em torno de 2 horas e 45 minutos para tomar totalmente a presa, enquanto que o amálgama leva 4 minutos. Quanto à resistência à compressão, em um período de 24 horas, o MTA apresentou a menor resistência (40Mpa) contra 312Mpa do amálgama, porém ela aumentou após 21 dias para 67Mpa. Quanto à solubilidade, apenas o IRM se mostrou solúvel. Quanto à composição, os autores relataram que os principais íons presentes no MTA são os de cálcio e fósforo, que também são os principais constituintes dos tecidos dentais, daí; segundo eles, a alta biocompatibilidade do material quando em contato com células e tecidos. Estes estudos também demonstraram que, após a presa, o MTA passa a ser constituído de óxido de cálcio na forma de cristais discretos e de fosfato de cálcio, com uma estrutura amorfa, com aparência granular. Os autores ainda relataram que a composição média dos prismas é de $87 \%$ de cálcio, 2,47\% de sílica e o restante de oxigênio. As áreas de estrutura amorfa contêm 33\% de cálcio, $49 \%$ de fosfato, $2 \%$ de carbono, 3\% de cloreto e $6 \%$ de sílica.

TORABINEJAD et al. $^{138}$, em 1995, comparam a citotoxicidade do amálgama, Super EBA, IRM e MTA usando células de rato L929. O amálgama foi o menos tóxico. O MTA foi significativamente menos tóxico que o Super EBA e o IRM.

Em outra experimentação, também em 1995, TORABINEJAD et al. ${ }^{139}$ compararam o efeito antimicrobiano do amálgama de prata, óxido de zinco e eugenol, super EBA e MTA, quando em mistura ainda fresca ou após 24 horas de presa, sobre 9 bactérias facultativas 
(Streptococcus faecalis, Streptococcus mitis, Streptococcus mutans, Streptococcus salivarius, Lactobacillus species, Staphylococcus aureus, Staphylococcus epidermidis, Bacillus subtilis, Escherichia coli) e 7 bactérias anaeróbias (Prevotella buccae, Bacterioides fragilis, Prevotella intermedia, Prevotella melaninogênica, Fusobacterium nucleatum, Peptostreptococcus anaerobius, F. necrophorum). Os materiais retrobturadores foram colocados na superfície do meio sólido e incubados por $24-48$ horas a $37^{\circ} \mathrm{C}$. O efeito antimicrobiano de cada material foi determinado medindo-se o diâmetro das zonas de inibição, em milímetros. Todos os materiais estudados não demonstraram atividade antimicrobiana sobre nenhum dos anaeróbios, no entanto com o MTA pode-se observar algum efeito em 5 dos 9 tipos de bactérias facultativas estudadas, sendo este efeito maior quando em mistura fresca. Ressaltaram os autores que o seu efeito antibacteriano está associado ao seu alto pH ou à liberação de substâncias difusíveis no meio de crescimento.

Neste mesmo ano, KETTERING; TORABINEJAD ${ }^{69}$ realizaram um estudo para avaliar o potencial mutagênico do MTA, Super EBA e IRM. Utilizaram a prova de AMES, que foi desenvolvida para avaliar atividade carcinogênica potencial em materiais sólidos e líquidos e cepas de salmonella typhimurium TA98 (cepa R-reagente) e TA1535 (não R-reagente) que eram colocadas num meio de cultura e depois em suspensão junto com os cimentos retrobturadores. Tais colônias, capazes de crescer, têm 90\% de probabilidade de se tornarem mutagênicas aos humanos, no entanto, os resultados obtidos indicaram que tanto o MTA, IRM e Super EBA não parecem apresentar potencial mutagênico.

Em 1996, BATES; CARNES; DEL RIO ${ }^{9}$ avaliaram o MTA, o amálgama + verniz e o Super EBA, quanto à microinfiltração, por meio do sistema de condução de fluídos. Foram empregados 72 dentes humanos extraídos, os quais foram apicectomizados, retropreparados e retrobturados com os materiais em estudo. Procedeu-se com a colocação dos espécimes em solução salina de fosfato tamponada em alta pressão. O MTA foi 
superior ao amálgama e comparável ao Super EBA quanto à habilidade de prevenir microinfiltração quando usado como material de preenchimento em retrobturação. Segundo os autores, este é o método mais eficiente para verificar microinfiltração, pois é capaz de mensurar a infiltração cumulativamente na interface material selador e superfície radicular, de forma quantitativa.

FORD et al. ${ }^{47}$, também em 1996, compararam as respostas da polpa dentária de macacos após emprego do MTA ou $\mathrm{Ca}(\mathrm{OH})_{2}$ como materiais capeadores pulpares. No grupo do MTA todas as amostras apresentaram formação de ponte de dentina e só um dos seis espécimes apresentava sinais de inflamação. No grupo do $\mathrm{Ca}(\mathrm{OH})_{2}$ somente 2 das 6 amostras tinham formação de ponte de dentina e todas apresentavam inflamação. Os autores concluíram que o MTA sela as portas de comunicação entre o sistema de canais e a superfície externa do dente, parecendo ser um bom material capeador pulpar.

Em 1997, KOH et al. ${ }^{70}$ estudaram o efeito do MTA sobre osteoblastos. Os autores observaram a produção de citocinas, osteocalcinas e a atividade da fosfatase alcalina em cultura de osteoblastos, da linhagem MG-63, na presença do MTA endurecido, em condições de umidade. O grupo controle foi formado por osteoblastos sem a presença do MTA. As interleucinas IL-1a, IL-1be e IL-6, o fator de estimulação de macrófagos e a osteocalcina foram observadas pelo teste ELISA. Os níveis de fosfatase alcalina foram medidos para o estabelecimento do nível de diferenciação dos osteoblastos Os resultados demonstraram que, os osteoblastos apresentavam-se aderidos ao MTA após 6 horas. Maior quantidade de IL-1a, IL-1b e IL-6 foi encontrada após 144 horas. O fator de estimulação de macrófago parece não ter sido afetado, mantendo-se em valores altos. No grupo controle, os osteoblastos produziram quantidade desprezível destas citocinas. Já a produção de osteocalcina aumentou na presença de MTA. Os autores concluíram que esse material não provoca alterações na morfologia das referidas células. 
Também em 1997, TORABINEJAD et al. ${ }^{142}$ avaliaram a resposta dos tecidos periapicais de dentes de macacos frente ao MTA e ao amálgama de prata. Após o período de 5 meses os autores relataram que, dos seis espécimes onde foi utilizado o MTA, cinco apresentavam barreira de tecido mineralizado em contato com o material e tecido conjuntivo isento de processo inflamatório. Esses resultados eram opostos aos resultados obtidos com o amálgama de prata, pois, em nenhum espécime havia selamento biológico e todos apresentavam processo inflamatório.

Um ano após, novamente TORABINEJAD et al. ${ }^{146}$, implantaram, em mandíbula e tíbia de porcos da Guiné, o MTA, o IRM, o amálgama e o Super EBA, materiais para obturação retrógrada. Verificaram a resposta tecidual por meio da análise microscópica considerando a quantidade de inflamação, o tipo de célula e a espessura do tecido conjuntivo encontrado ao redor dos materiais implantados. Os autores relataram que o maior índice de inflamação foi encontrado com o amálgama e o menor com o MTA.

FISCHER; ARENS; MILLER ${ }^{46}$, também em 1998, avaliaram a infiltração bacteriana do MTA, Super EBA, IRM e amálgama quando empregados em retrobturações. Foram utilizados 56 dentes unirradiculados, nos quais, após o preparo e obturação do canal, foi realizada apicectomia em $3 \mathrm{~mm}$ e retropreparo de $3 \mathrm{~mm}$ de profundidade com o auxílio de pontas ultra-sônicas. Os dentes foram esterilizados e divididos em 4 grupos de 10. O controle positivo foi a guta-percha sem cimento e o controle negativo a cera pegajosa. Os dentes foram impermeabilizados com esmalte de unha, colocados dentro de um tubo de plástico com meio de cultura e presos na região da junção cemento- esmalte. Foi inoculado 0,1 ml de cultura de serratia marcences dentro do canal que caso chegasse ao ápice, a coloração do meio de cultura mudaria. Os dentes foram avaliados por um período de 120 dias. O MTA promoveu um melhor selamento apical sendo que suas amostras começaram a corar com 49 dias e ao final de 120 dias, 
das 10, ainda restavam 4 amostras sem infiltração. Os dados, quando submetidos a análise estatística, demonstraram que o MTA foi superior.

Em 1998, NAKATA; BAE; BAUMGARTNER ${ }^{91}$ realizaram uma pesquisa semelhante utilizando 39 molares superiores e inferiores humanos extraídos simulando perfurações de furca comparando o MTA com o amálgama, em um modelo de infiltração para anaeróbio. Neste estudo, nos dentes selados com MTA não houve a passagem de F.nucleatum, já no grupo selado com amálgama, a infiltração foi significativamente maior.

OSÓRIO, et al. ${ }^{100}$, em 1998, avaliaram "in vitro" a citotoxicidade dos cimentos endodônticos Endomet, CRCS e AH26 e dos materiais retrobturadores amálgama, Gallium GF2, Ketac silver, MTA e Super EBA. Realizaram culturas de células fibroblásticas humanas L929, e utilizaram o ensaio MTT para avaliar a capacidade da enzima mitocondrial e o ensaio de cristal violeta para avaliar o número de células. Os resultados demonstraram que o MTA não é citotóxico, que o Gallium GF2 apresenta leve efeito citotóxico e o Ketac Silver, Super-EBA e amálgama demonstraram elevados graus de citotoxicidade.

SLUYK; MOON; HARTWELL ${ }^{128}$, ainda em 1998, avaliaram o efeito do tempo e da umidade na presa, retenção e adaptação do MTA quando empregado como material selador de perfurações de furca. Foram utilizados 32 molares humanos extraídos, os quais tiveram as coroas removidas em um nível acima do assoalho da câmara pulpar, e as raízes removidas logo abaixo da região de furca. O espécime em estudo foi montado em uma base de resina acrílica, perfurado com brocas esféricas n² e alargado com broca Gates-Glidden n05. Para simular a situação clínica uma espuma de Gelfoam umedecida foi colocada em baixo da perfuração. Obturaram-se os espécimes com MTA e, sobre ele, uma mecha de algodão seca ou úmida foi colocada por um período de 24 ou 72 horas. Utilizando-se do teste de "Instron" obteve-se os valores da força requerida para deslocar o material da perfuração. Como conclusão os autores relataram que o MTA resistiu ao deslocamento a um nível significante maior em 72 horas do que 
em 24 horas e que, quando um ligeiro deslocamento ocorreu no período de 24 horas, o material demonstrou capacidade de restabelecer resistência ao deslocamento das paredes dentinárias. A presença de umidade após o selamento resultou em melhoria na adaptação do MTA às paredes da perfuração, entretanto não houve diferença significativa na retenção do MTA quando bolinhas de algodão secas ou úmidas foram colocadas na câmara pulpar durante o período experimental.

No final de 1998 este agregado de trióxidos minerais foi aprovado pela FDA e lançado comercialmente em 1999 como ProRoot MTA pela Dentsply Tulsa Dental, Oklahoma - USA (BERNABÉ; HOLLAND ${ }^{22}$, 2003).

Em 1999, ADAMO et al. ${ }^{2}$ realizaram trabalho semelhante ao de FISCHER; ARENS; MILLER ${ }^{46}$, de 1998, utilizando 60 dentes unirradiculados comparando o MTA, o Super EBA, resina e amálgama, em um modelo de infiltração bacteriana de $S$. salivarius. Os autores não encontraram diferenças significantes entre os grupos, que foram avaliados até 12 semanas.

MITCHELL et al. $^{84}$, também em 1999, avaliaram a biocompatibilidade do MTA em cultura de células MG63, que possuem propriedades fisiológicas e adesivas semelhantes às dos osteoblastos, observando a morfologia, o crescimento celular e a liberação de citocinas. 0 crescimento celular foi quantificado por amostras preparadas aos 2, 4 e 7 dias e analisadas com o microscópio eletrônico. As amostras de cultura foram testadas por meio do teste ELISA para observação da presença de IL1a, IL-6, IL-8, IL-11 e fator estimulante para colônias de macrófagos. Os resultados demonstraram crescimento celular e produção elevada de fator estimulante para colônias de macrófagos na presença do MTA. Após emprego do MTA foi evidenciado que, IL-6 e IL-8, estavam presentes. Já a IL-1a e IL-11 estavam ausentes. 
Neste mesmo ano, 1999, WUCHERPFENING; GREEN ${ }^{156}$ publicaram um abstract sobre o MTA que despertou ainda mais a curiosidade dos pesquisadores. Neste pequeno resumo eles afirmaram ter observado que esse material era quase idêntico, macroscopica e microscopicamente, pela difração de raios- $X$, ao cimento Portland, cimento este, empregado na construção civil. Relataram, ainda, que os dois materiais tiveram comportamento similar quando em cultura de células e, também, quando aplicados em polpas de dentes de ratos.

HOLLAND et al. ${ }^{62}$, em 1999, estudaram a reação do tecido subcutâneo de ratos ao implante de 40 tubos de dentina preenchidos com MTA e Hidróxido de cálcio quimicamente puro. As peças foram removidas após 7 e 30 dias e processadas sem descalcificação. Assim, cortes em micrótomo de tecido duro foram realizados e analisados com auxílio de um microscópio de luz polarizada e coloração de Von Kossa para sais de cálcio. Notaram que, com o hidróxido de cálcio havia formação de granulações de calcita birrefringentes à luz polarizada, junto à abertura do tubo e abaixo dessas granulações notou-se a formação de ponte de tecido duro Von Kossa positivo. As granulações birrefringentes a luz polarizada também estavam presente no interior dos túbulos dentinários. Os resultados quando se empregou o MTA foram iguais àqueles observados com o emprego do hidróxido de cálcio, notando-se apenas que o número das granulações de calcita eram um pouco menor que no grupo do hidróxido de cálcio e que essas granulações estavam em contato com o material estudado, o que não ocorria com o hidróxido de cálcio. Os autores ainda relataram que o óxido de cálcio presente no MTA, quando em contato com a água, seria convertido em hidróxido de cálcio que, em contato com os fluidos teciduais, se dissociaria em íons $\mathrm{Ca}^{2+}$ e $\mathrm{OH}^{-}$. Os íons cálcio, reagindo com o $\mathrm{CO}_{2}$ dos tecidos daria origem às granulações de calcita, gerando o acúmulo de fibronectina, que por sua vez propiciaria a migração, adesão e diferenciação celular com conseqüente formação de tecido duro. 
Também em 1999, HOLLAND et al. ${ }^{60}$ observaram a reação dos tecidos periapicais de dentes de cães, após obturação de canais com MTA. Foram utilizados 30 canais radiculares, os quais foram preparados biomecanicamente e obturados pela técnica da condensação lateral com cones de guta-percha e MTA ou ionômero de vidro (Ketac Endo). Após 6 meses, verificaram que nos casos onde o cimento utilizado foi o MTA havia 100\% de deposição de novo cemento na região periapical e nenhuma reação inflamatória. Já com o uso do Ketac Endo não houve deposição de cemento e em 2 casos houve extravasamento com intensa reação inflamatória

Ainda, em 1999, MORANDI $^{87}$ realizou um experimento em dentes de cães portadores de lesões periapicais após apicectomia e obturação retrógrada convencional com o MTA e cimentos à base de óxido de zinco e eugenol. Após 180 dias dos procedimentos operatórios, os autores relataram que o MTA, o Super EBA e o IRM apresentaram resultados microscópicos semelhantes e superiores aos do cimento de óxido de zinco e eugenol consistente. Entretanto, dos três materiais, o MTA foi o único que estimulou a deposição de tecido mineralizado junto à superfície apicectomizada e material retrobturador.

Em 2000, ESTRELA et al. $^{44}$ realizaram um teste de difusão em agar utilizando 4 cepas bacterianas: staphylococcus aureus, enterococcus faecalis, pseudomonas aeruginosa e bacillus subtilis e um tipo de fungo: cândida albicans, comparando o MTA, cimento Portland, pasta de $\mathrm{Ca}(\mathrm{OH})_{2}$, Sealapex e Dycal. A atividade antimicrobiana da pasta de $\mathrm{Ca}(\mathrm{OH})_{2}$ foi superior a todas as outras substâncias, apresentando zonas de inibição com 6-9,5 mm e zonas de difusão com 10-18 mm. O MTA, o cimento Portland e o Sealapex apresentaram apenas zonas de difusão, com superioridade para o último. Os autores também avaliaram e compararam os elementos químicos presentes nesses materiais demonstrando que 0 cimento Portland e o MTA contêm os mesmos elementos químicos, exceto o bismuto, presente no último. 
KEISER; JOHNSON; TIPTON ${ }^{68}$, em 2000, investigaram a citotoxicidade do MTA, quando comparado ao Super EBA e amálgama usando cultura de fibroblastos do ligamento periodontal, obtidos de raízes de $3^{\mathrm{os}^{\mathrm{S}}}$ molares impactados. O MTA demonstrou ser menos tóxico para células humanas do ligamento periodontal que o Super EBA em todas as concentrações estudadas, tanto no estado fresco quanto após 24 horas, isto é, após presa. Mostrou-se também, menos tóxico que o amálgama.

Também, em 2000, $\mathrm{KOH}$ et al. $^{70}$ realizaram cultura de osteoblastos humanos (MG-63) na presença de MTA e PMA (polimetilmetacrilato), cimento este, muito empregado na ortopedia. Os autores observaram o comportamento dos osteoblastos quanto à produção de citoquinas e osteocalcina e a atividade da fosfatase alcalina. Verificaram que a produção de citoquinas e osteocalcina aumentava na presença do MTA, permitindo a aderência das células ao material. Também foi encontrada atividade da fosfatase alcalina sobre o MTA. Entretanto, com o PMA não se detectou osteocalcina, nem atividade da fosfatase alcalina.

Ainda em 2000, ZHU et al. ${ }^{159}$ observaram a adesão de osteoblastos humanos aos materiais IRM, MTA, resina composta e amálgama empregados para retroobturação. Com auxílio do MEV os autores verificaram que os osteoblastos têm uma excelente adesão ao MTA e à resina, comparadas ao IRM e amálgama.

Por meio da difração de raios-X, HERZOG-FLORES et al. ${ }^{55}$, em 2000, analisaram a composição físico-química do MTA, demonstrando que $18 \%$ dele é insolúvel em água, 0,36\% corresponderia ao óxido de magnésio e $90 \%$ ao óxido de cálcio, sendo sua estrutura $80 \%$ cristalina. Por meio de espectrofotômetro de absorção atômica, pode-se quantificar a liberação de íons cálcio do material em 24 horas, 7 e 15 dias, resultando em valores de 8,8 ppm, 10,08 ppm, 10,10 ppm, respectivamente.

Paralelamente, também em 2000, SAFAVI; NICHOLS ${ }^{115}$ publicaram um abstract relatando o efeito do MTA e do cimento Portland na 
secreção de $\mathrm{PGE}_{2}$ de monócitos. Os autores demonstraram que os produtos solúveis do MTA e do cimento Portland apresentaram um efeito inibitório similar sobre a secreção de $\mathrm{PGE}_{2}$ de monócitos.

AQRABAWI $^{7}$ (2000) avaliou a capacidade de selamento apical do Super EBA, do amálgama e do MTA empregados como materiais retrobturadores em dentes humanos extraídos. Foram, empregados 79 caninos humanos extraídos, os quais tiveram suas coroas seccionadas, os canais instrumentados e obturados. Seqüencialmente realizou-se a ressecção dos $3 \mathrm{~mm}$ apicais, o preparo de retrocavidades com o auxílio de pontas ultra-sônicas e a retrobturação dos espécimes. Após imersão em azul de metileno a 1\%, durante 72 horas, e avaliação em aumento de 10X em estereomicroscópio pode-se apurar os resultados e verificar que eles estão de acordo com aqueles apresentados por LEE; MONSEF; TORABINEJAD ${ }^{78}$, em 1993, onde o MTA foi o material que se mostrou mais resistente à penetração do corante na interface com a superfície dentinária.

KWAK; PARK; $\mathrm{OH}^{72}$ (2000) realizaram um estudo "in vitro" para avaliar a influência da espessura do plug apical de MTA obturando o canal radicular logo após sua confecção ou 24 horas depois. Observaram que a obturação do canal radicular imediatamente após a utilização do plug apical não prejudicou a capacidade seladora do material. Além do que notaram que a espessura do plug também não influía no selamento marginal, nem mesmo havendo o deslocamento do plug.

MORETTON et al. ${ }^{88}$, ainda em 2000, avaliaram, comparativamente, a biocompatibilidade, a osteocondução e a osteoindução do MTA e do Super EBA por meio de implantes subcutâneos e intra-ósseos realizados em ratos, com períodos experimentais de 30 e 60 dias. Ao implante subcutâneo, a resposta inflamatória ao MTA foi considerada severa e ao Super EBA moderada e diminuía em 60 dias. Entretanto, ao implante intra-ósseo, as reações, tanto do MTA quanto do Super EBA, foram menos intensas. O padrão de osteogênese entre os materiais foi semelhante. Os 
autores concluíram que os materiais não são osteoindutores, mas sim osteocondutores.

Em 2001, SCHEERER; STEIMAN; COHEN ${ }^{123}$ avaliaram a infiltração bacteriana com Prevotella nigrescens utilizando como materiais retrobturadores o MTA, Super EBA e Geristore (ionômero de vidro). Os dentes tiveram os canais instrumentados com instrumentos rotatórios Profile serie 29 e apicectomizados em 3mm. Procedeu-se com o preparo de retrocavidades com pontas ultra-sônicas e retrobturações com os materiais em estudo. Os resultados encontrados não apresentaram diferenças significantes entre os 3 materiais para a penetração da bactéria, no período de 47 dias.

HOLLAND et al. ${ }^{59}$, em 2001, realizaram um estudo para observar a reparação tecidual da zona de furca em perfurações radiculares laterais intencionais, seladas com MTA ou Sealapex. Foram utilizados 48 dentes de cães, os quais tiveram os canais instrumentados, obturados e, por fim, realizou-se perfurações radiculares laterais com broca, sendo uma em cada dente. Uma metade das perfurações foram preenchida com MTA e a outra com Sealapex consistente. Os períodos de observação foram de 30 e 180 dias. Os autores relataram que a deposição de cemento foi maior no grupo do MTA e que a reação inflamatória era de menor intensidade nesse grupo. De todos os espécimes analisados 7 do grupo do MTA e 15 do grupo do Sealapex tiveram o material extravasado e os melhores resultados foram obtidos quando o material não extravasou.

Novamente, HOLLAND et al. $^{63}$, em 2001, em estudo semelhante ao de 1999, estudaram a reação do tecido subcutâneo de ratos ao implante de tubos de dentina preenchidos com MTA, Hidróxido de cálcio quimicamente puro e cimento Portland. Os autores relatam que, além de observarem granulações de calcita em contato com os materiais e no interior dos túbulos dentinários, observaram a presença de ponte de tecido duro pelo método de Von Kossa. Diante dos resultados obtidos os autores concluíram que os 3 materiais estudados apresentam mecanismos de ação 
semelhante, e são capazes de estimular a deposição de tecido duro junto deles.

HOLLAND et al. $^{58}$ (2001) em um estudo em 26 dentes de cães, realizaram pulpotomia protegendo os remanescentes pulpares com 0 MTA ou cimento Portland. Decorridos 60 dias pós experimentais as peças foram preparadas para análise microscópica. Tal análise permitiu identificar 10 espécimes do grupo do MTA com ponte completa de tecido duro e ausência de sinais inflamatórios, contra 11 casos do cimento Portland. Os autores relataram que os caso que não obtiveram pontes completas foram aqueles onde ocorreram problemas com o selamento coronário ou simplesmente exibiram irregularidades e solução de continuidade na porção central da ponte.

Foi realizado também, por HOLLAND et al. ${ }^{57}$, em 2001, um trabalho empregando, em dentes de cães, o MTA como cimento obturador de canais radiculares e comparando-o ao cimento Portland. Os cimentos foram preparados com soro fisiológico e introduzidos no interior dos canais com espirais Lentulo, realizando-se a obturação pela técnica da condensação lateral ativa. Decorridos 90 dias pode-se observar em 8 dos 10 espécimes obturados com o MTA o selamento biológico total, sendo que os outros 2 espécimes exibiram selamento parcial. Com o cimento Portland observou-se 7 casos de selamento biológico completo, 2 casos de selamento parcial e 1 caso com ausência de selamento.

FARACO JÚNIOR; HOLLAND ${ }^{45}$ (2001) avaliaram microscopicamente a resposta da polpa de dentes de cães que sofreram capeamento com sistema adesivo, cimento de hidróxido de cálcio e dois tipos de agregados de trióxidos minerais, o MTA cinza e o MTA branco. Para tal, utilizaram 30 dentes de cães onde na região cervical da face vestibular foram realizadas exposições pulpares e capeadas com um dos materiais aleatoriamente. A análise, sob microscopia ótica, dos efeitos desses materiais no tecido pulpar, demonstrou, após 60 dias, que os dois tipos de 
MTA foram superiores em relação aos outros materiais, inclusive, estimulando a deposição de tecido duro.

Neste mesmo ano, DALÇÓQUIO et al. $^{38}$ realizaram um trabalho quanto à infiltração apical após retrobturações empregando MTA, Ketac-Fil, IRM, ionômero de vidro e cianocrilato. Após apicectomia em 120 dentes humanos extraídos, cavidades retrógradas de $3 \mathrm{~mm}$ de profundidade foram preparadas com auxílio do ultra-som e retrobturações realizadas com os diferentes materiais em estudo. Após imersão em corante azul de metileno e análise por meio de espectrofotometria aos 2, 7 e 60 dias, os autores relataram que os melhores resultados foram obtidos com o emprego do MTA, sendo que, aos 7 dias os valores foram significantes do ponto de vista estatístico.

Em 2002, DAOUDI; SAUNDERS ${ }^{39}$ realizaram um estudo com o MTA e Vitrebond, (cimento de ionômero de vidro), utilizando-os no selamento de perfurações dentárias, avaliando a influência do microscópio operatório quando na manipulação desses materiais. Após imersão em tinta da Índia, e processo de diafanização, o MTA mostrou ser superior ao Vitrebond: Somente $20 \%$ das amostras de MTA apresentavam sinais de infiltração e eram mínimas. O emprego do microscópio operatório não influenciou significantemente na performance de ambos materiais.

ANDELIN et al. ${ }^{5}$, em 2002, avaliaram a microinfiltração após apicectomia em canais obturados só com MTA comparando com canais obturados com guta-percha e cimento e retrobturados com MTA. Objetivouse com esse trabalho avaliar a possibilidade de se obturar os canais de dentes indicados para cirurgia parendodôntica com MTA e durante o procedimento cirúrgico proceder somente ao corte da porção apical da raiz. A amostra foi de 46 dentes unirradiculados, sendo 20 obturados com MTA, 20 com guta-percha e cimento e 6 para os controles positivo e negativo. Nos dentes do $2^{\circ}$ grupo foram preparadas cavidades apicais que receberam como material retrobturador o MTA. Nos do $1^{\circ}$ grupo, que previamente foram obturados com MTA foi realizada apenas apicectomia. As raízes de todos os 
dentes foram deixadas em contato com tinta da Índia por 48 horas. Os autores relataram que não houve diferença significante entre os dois grupos, ressaltando que, o fato de se obturar previamente o canal com MTA e depois cortar o ápice, beneficiaria os casos onde o preparo da cavidade retrógrada é muito difícil.

Ainda, em 2002, WELDON et al. ${ }^{154}$ compararam o MTA e o Super EBA, quando utilizados para selar perfurações de furca. Foram utilizados 51 molares humanos extraídos, os quais tiveram suas coroas seccionadas no limite cemento esmalte e as raízes removidas abaixo da região de furca, onde foram realizadas perfurações, que foram seladas com os materiais em teste. Utilizando-se de sistema semelhante ao de BATES; CARNES; DEL RIO ${ }^{9}$, de 1996, para avaliar a microinfiltração por meio do sistema de condução de fluídos, os autores observaram que o Super EBA apresentou menor infiltração, porém só no período de 24 horas. Nos períodos de uma semana e 1 mês ambos os materiais selaram bem as perfurações.

Em 2002, PETERS; PETERS ${ }^{103}$ avaliaram em MEV a adaptação marginal do Super EBA e MTA, antes e depois de submetidos à carga oclusal por um período equivalente a 5 anos em um computador de controle mastigatório. Utilizaram 12 molares superiores e 12 inferiores extraídos, onde o modelo mastigatório era feito contactando o molar superior com o inferior. Nos molares superiores prepararam as raízes mésiovestibulares e as palatinas e nos inferiores prepararam as duas raízes. Cada dente teve a cavidade de retropreparo de uma raiz preenchida com MTA e a outra com Super EBA. Foi avaliada a formação de "cracks" após carga oclusal e adaptação marginal. Os autores relataram que os dois materiais apresentaram excelentes resultados, pois ocorreram a formação de "cracks" em $12,8 \%$ das raízes antes da carga oclusal e em $23,5 \%$ delas depois da mesma carga.

Neste mesmo ano, TANG; TORABINEJAD; KETTERING ${ }^{134}$ estudaram a infiltração de endotoxinas em 104 raízes preparadas e 
retrobturadas com amálgama, IRM, Super EBA e MTA. Para o procedimento foi utilizado um kit para presença de endotoxina QCL 1000. As amostras foram avaliadas após 1, 2, 6 e 12 semanas. Após 1 semana o MTA infiltrou menos que o IRM e o amálgama e foi semelhante ao Super EBA. Em 2 semanas o MTA infiltrou significativamente menos que o amálgama, IRM e Super EBA repetindo estes dados em 6 e 12 semanas. Não houve diferença significante entre IRM, Super EBA e amálgama nos tempos avaliados.

SAIDON; SAFAVI; SPANGBERG ${ }^{117}$, em 2002, realizaram implantes de MTA e de cimento Portland em mandíbulas de cobaias. Após 2 e 12 meses os autores verificaram que o reparo ósseo continha um infiltrado inflamatório mínimo adjacente a ambos os materiais, comprovando que os mesmos são bem tolerados quando implantados em cavidades ósseas.

TZIAFAS et al. $^{151}$ (2002) avaliaram a resposta celular de polpa de cães expostas mecanicamente e preenchidas com MTA. Os autores concluíram que o MTA é um material capeador pulpar efetivo, capaz de estimular a formação de dentina reparativa pelos mecanismos de defesa da polpa.

HOLLAND et al. $^{61}$ (2002) estudaram novamente no tecido subcutâneo de ratos a reação a implantes de tubos de dentina preenchidos com MTA branco, cimento este que havia surgido no mercado americano naquela época, e observaram que os resultados foram semelhantes aos já estudados com o MTA cinza.

BERNABÉ et al. ${ }^{16}$, ainda em 2002, demonstrou a superioridade do MTA frente ao IRM, Super EBA, e OZE consistente, quando empregados como materiais retrobturadores em dentes de cães portadores de lesão periapical. Após apicectomia realizada com broca Zekria, retrocavidades foram preparadas com o auxílio de pontas ultrasônicas e os materiais, aleatoriamente, preenchiam as cavidades ficando rente à superfície apicectomizada. Após 180 dias, além da superioridade do MTA, os autores ainda relataram que esse material foi o único capaz de 
estimular a deposição de tecido mineralizado sobre si, à semelhança dos resultados obtidos por TORABINEJAD et al. ${ }^{142,143}$, em 1995 e 1997.

Novamente BERNABÉ et al. ${ }^{19}$, em 2002, aplicaram essa mesma metodologia para comparar o MTA ao cimento Portland, e após 180 dias observaram resultados similares entre estes materiais, ressaltando que grande parte dos espécimes de ambos, apresentaram selamento biológico.

Com o propósito de se avaliar, além da influência do material retrobturador, a influência do tipo de retropreparo, BERNABÉ et al. ${ }^{17}$ (2002) realizaram um trabalho em dentes de cães empregando o MTA e o cimento de OZE consistente em cavidades retrógradas preparadas com brocas esféricas e com ultra-som. Os resultados foram avaliados 180 dias após os procedimentos experimentais e demonstraram, mais uma vez, que o MTA foi superior ao cimento de OZE consistente, e neste caso, independente do tipo de preparo, se com broca ou ultra-som.

Ainda, em 2002, DEAL, et al. ${ }^{40}$ estudaram o ProRoot MTA, o cimento Portland e um MTA experimental com a presença de aceleradores de presa. Encontraram, logo após a manipulação, valores de pH em torno de 11,6, para o ProRoot MTA, 11,72 para o cimento Portland e 11,74 para 0 MTA experimental. Após 30 minutos da mistura os valores estavam em 12,3 para o ProRoot MTA e cimento Portland enquanto que o MTA experimental não pode ser aferido pois já estava sólido. Neste mesmo experimento foi avaliado o tempo de presa desses 3 materiais chegando aos resultados de 2 horas e 36 minutos para o ProRoot MTA, 2 horas e 39 minutos para cimento Portland e 17 minutos para o MTA com acelerador de presa.

BERNABÉ et al. $^{14}$ (2002) avaliaram a capacidade de selamento marginal do MTA, IRM, Super-EBA, ionômero de vidro e amálgama de prata com verniz (Copalite) em 70 dentes humanos recém extraídos. Os autores realizaram retrobturações com os cinco materiais após apicectomia e preparo de retrocavidades com ultra-som e imergiram os 
espécimes em azul de metileno. Os resultados exibiram menor índice de infiltração no grupo do MTA quando comparado com os outros materiais.

TANOMARU FILHO et al. ${ }^{136}$, também em 2002, avaliaram a capacidade de selamento marginal do MTA, em perfurações radiculares laterais simuladas em dentes humanos extraídos, comparando com cimento de óxido de zinco e eugenol e Sealer 26. Os resultados observados após imersão em azul de metileno demonstraram que o Sealer 26 e o MTA se comportaram de maneira similar e que foram superiores ao cimento de óxido de zinco e eugenol.

Noutro trabalho semelhante de 2002, TANOMARU FILHO et al. ${ }^{135}$ avaliaram a capacidade seladora do Sealapex consistente, Dyract, Vitremer, ProRoot MTA e MTA Ângelus. Os resultados não demonstraram diferenças estatisticamente significante entre esses materiais.

Em 2003, GONÇALVES; BRAMANTE ${ }^{50}$ realizaram um trabalho "in vitro" em 90 caninos humanos extraídos avaliando a capacidade seladora do Super EBA e do MTA em quatro técnicas de obturação retrógrada, a obturação retrógrada convencional realizado-se a cavidade com broca de aço $n^{\circ} 2$, o tratamento endodôntico via retrógrada, realizado com auxílio de limas, a associação de ambas e a técnica da canalização (cavidade retrógrada classe II). Os espécimes depois de preparados e retrobturados foram imersos em Rodamina B permanecendo por 72 horas em estufa a $37^{\circ} \mathrm{C}$. Os resultados obtidos demonstraram não haver diferenças significantes entre os materiais em todas as técnicas estudadas.

GOMES et al. ${ }^{49}$ (2003) realizaram um experimento "in vitro" com 56 dentes humanos extraídos para avaliar a capacidade de selamento do Super EBA e do MTA em cavidades retrógradas preparadas com broca ou com ultra-som. Os espécimes, depois de preparados e retrobturados, foram imersos em tinta nanquim por 48 horas e analisados quanto à infiltração marginal em estereomicroscópio. Os resultados encontrados não demonstraram diferenças entre os materiais utilizados, entretanto, houve 
diferença entre as técnicas, sendo que o preparo com o ultra-som exibiu os menores índices de infiltração.

ECONOMIDES et al. $^{43}$ (2003) avaliaram a resposta dos tecidos periapicais frente ao emprego do MTA e do IRM em cavidades retrógradas realizadas em dentes de cães. Os dentes tiveram suas polpas removidas, os canais preparados e obturados com guta-percha e cimento endodôntico. Em uma segunda etapa as raízes foram apicectomizadas, as retrocavidades preparadas e obturadas com um dos materiais em estudo. Após 1 e 5 semanas dos procedimentos experimentais a avaliação microscópica levou os autores a concluírem que o MTA representa um substrato biocompatível ao qual as células formativas podem se aderir, estimulando o reparo dos tecidos periapicais.

AEINEHCHI et al. $^{3}$, também publicaram um trabalho em 2003, avaliando o MTA e o hidróxido de cálcio como materiais capeadores recobertos por ZOE e restaurados com amálgama. Utilizaram 11 pares de terceiros molares humanos que foram submetidos à exposição pulpar e receberam um dos materiais em estudo. Os dentes foram extraídos nos períodos de uma semana, 2, 3, 4 e 6 meses. A avaliação microscópica demonstrou menor inflamação, hiperemia e necrose com o emprego do MTA, além de ponte de dentina mais espessa e formação de camada odontoblástica abaixo do material em maior quantidade do que com o $\mathrm{Ca}(\mathrm{OH})_{2}$.

Segundo BERNABÉ; HOLLAND ${ }^{22}$, no ano de 2003, após inúmeras pesquisas que demonstraram a similaridade do MTA com o cimento Portland, o fabricante do ProRoot MTA modificou algumas informações contidas no MSD original, acrescentando que o material era composto por $75 \%$ de Cimento Portland, $20 \%$ de óxido de bismuto, e $5 \%$ de sulfato de cálcio di-hidratado. Ressaltou o autor que esses dados eram omitidos até então, pois desde 1999 os trabalhos experimentais e bulas originais não informavam a verdadeira identidade do MTA. 
Em 2004, BERNABÉ et al. ${ }^{13}$ realizaram uma experimentação "in vitro" com o propósito de se avaliar a capacidade seladora marginal e a infiltração na massa do MTA Ângelus, do ProRoot MTA, do Cimento Portland (Itaú) e do cimento Sealapex consistente. Sessenta dentes humanos recém extraídos tiveram seus canais instrumentados e obturados com cimento Sealapex, pela técnica da condensação lateral ativa. Os dentes foram impermeabilizados e seccionados os $3 \mathrm{~mm}$ apicais. Retrocavidades foram preparadas com o auxílio de pontas ultra-sônicas diamantadas e retrobturadas aleatoriamente. Após a presa dos materiais, os espécimes foram mergulhados em azul de metileno a 2\% e pH neutro por 15 minutos em vácuo, permanecendo nesta solução por mais 24 horas. Os corpos de prova foram lavados, secados e clivados longitudinalmente para avaliação da infiltração do corante na interface dentina/material retrobturador e da infiltração do corante na massa do material. As imagens foram captadas por uma câmara acoplada a um microscópio e analisadas com o auxílio do programa SigmaScan. A análise dos resultados demonstrou não haver diferenças estatisticamente significante entre as infiltrações ocorridas na interface dos materiais estudados. No entanto, a infiltração em massa dos materiais retrobturadores foi significante do ponto de vista estatístico e podem ser ordenadas do melhor para o pior da seguinte maneira: ProRoot MTA, Cimento Portland, Sealapex consistente e MTA Ângelus. Os resultados também demonstraram não haver uma correlação entre a infiltração sofrida na interface e na massa dos materiais quando analisados separadamente.

MENEZES et al. ${ }^{83}$ (2004) avaliaram a resposta da polpa dentária de dentes de cães após pulpotomia e proteção pulpar direta com MTA Ângelus, ProRoot MTA, cimento Portland e cimento Portland branco. O estudo constou de 76 dentes de 4 cães com idade entre 12 e 18 meses, divididos em 4 grupos de 19 espécimes cada. Após 120 dias os animais foram mortos e as peças processadas laboratorialmente para análise microscópica. A partir dos dados coletados, os autores relataram que os quatro materiais apresentaram resultados semelhantes quando empregados 
em pulpotomias. Todos os espécimes mantiveram a vitalidade pulpar e havia formação de ponte de tecido duro logo abaixo do material.

YALTIRIK et al. ${ }^{157}$, também em 2004, avaliaram a reação do tecido conjuntivo subcutâneo de ratos frente ao emprego do MTA e do amálgama. Para tal, implantaram tubos de polietileno contendo os materiais, os quais foram avaliados após 7, 15, 30, 60, e 90 dias dos procedimentos experimentais. A análise microscópica foi realizada por meio da atribuição de escores, onde foram verificados a presença de inflamação, os tipos celulares predominantes, a presença de calcificações, e a formação de tecido conjuntivo fibroso. Os autores relataram que após o período de 90 dias ambos materiais foram bem tolerados pelo organismo, apesar de que, nos períodos menores, o MTA ter sido superior. Encontraram, ainda, calcificações distróficas quando do emprego do MTA, e salientaram, que este achado, sustenta a hipótese de indução de tecido duro.

$$
\text { APAYDIN; SHABAHANG; TORABINEJAD }{ }^{6}
$$

avaliaram, em dentes de cães, a resposta tecidual periapical ao MTA, quando da sua aplicação logo após a espatulação ou após presa. Utilizaram 24 pré-molares mandibulares de quatro cachorros, os quais tiveram seus canais preenchidos por MTA. Após período de 2 semanas, realizaram as cirurgias experimentais onde procederam à apicectomia de todas as raízes. Metade delas, foram preparadas com auxílio do ultra-som e retrobturadas com MTA, logo após espatulação. O propósito deste trabalho foi avaliar se, para os casos de cirurgias parendodônticas, seria possível obturar-se previamente o canal e durante o procedimento cirúrgico proceder apenas à apicectomia. Decorridos 4 meses, dos procedimentos cirúrgicos, os animais forma mortos e as peças processadas para análise microscópica e histométrica. Os resultados indicaram que, embora o MTA, empregado logo após a espatulação, tenha apresentado uma incidência significativamente mais alta de formação de cemento, pois 12 de 12 contra 8 de 12 espécimes apresentaram esta formação tecidual, não houve diferença significante do 
ponto de vista estatístico entre estas duas técnicas quanto à quantidade de tecido cementóide e ósseo formado.

BONSON; JEANSONNE; LALLIER ${ }^{24}$, ainda em 2004, avaliaram a diferenciação de fibroblastos quando da presença do MTA. Os autores observaram uma proliferação fibroblástica aumentada quando da presença do MTA e uma indução na expressão da fosfatase alcalina. Relataram, ainda, que, na presença do amálgama os fibroblastos sobreviveram. Por outro lado, observaram que o compômero inibiu a atividade da fosfatase alcalina. Como conclusão os autores relataram que os materiais empregados em retrobturações influenciam diferentemente na diferenciação dos fibroblastos.

PELLICCIONI et al. ${ }^{102}$ (2004) avaliaram a aderência, a viabilidade, a proliferação e a secreção de colágeno de osteoblastos "like". O estudo constou da exposição destas células ao ProRoot MTA, Super EBA e amálgama, durante 24 e 72 horas. Os autores observaram células aderidas na superfície do MTA que se apresentavam viáveis. Notaram, também, que estas células cresceram e liberaram colágeno. Entretanto, na presença do Super EBA e amálgama, notaram que o metabolismo e o crescimento celular estavam significativamente reduzidos. Como conclusão relataram que, o Proroot MTA demonstrou uma boa interação com as células formadoras de tecido ósseo.

BERNABÉ, et al. ${ }^{18}$ (2004) realizaram um trabalho cujo objetivo foi avaliar "in vivo" a eficiência do selamento marginal via coronária do MTA utilizado como material retrobturador comparado ao cimento de óxido de zinco e eugenol na forma consistente. Foram utilizadas 48 raízes de 24 pré-molares de três cães adultos. Após a anestesia e antissepsia, foi realizada a abertura coronária, odontometria, pulpecctomia, instrumentação até o platô apical e metade dos dentes recebeu obturação dos canais. Seguida a incisão e rebatimento do retalho, foi realizada ostectomia, apicectomia em ângulo reto, preparo das retrobturações com ultra-som e ponta S15 RD e S15 LD (Gnatus) para confecção das retrocavidades e 
retrobturações com MTA ou OZE consistente. Os canais que não foram obturados via coronária não receberam selamento coronário e permaneceram expostos ao meio bucal. Contudo, os canais que foram obturados via coronária receberam selamento coronário. Após 180 dias dos procedimentos cirúrgicos, os animais foram sacrificados, a maxila e a mandíbula removidas, fixadas e descalcificadas para o processamento histológico de rotina com coloração com HE e Brown \& Brenn. Os resultados demonstraram que o MTA, independente da situação, em canais com ou sem obturação/selamento coronário, apresentou resultados mais favoráveis que aqueles exibidos com a utilização de OZE consistente. Os autores concluíram que o MTA foi o material retrobturador mais eficiente com relação ao selamento e o único a estimular a formação de tecido mineralizado em contato direto com o material retrobturador.

Novamente BERNABÉ, et al. $^{15}$, em 2004, avaliaram microscopicamente o reparo dos tecidos periapicais de dentes de cães portadores de lesão periapical após retrobturação com MTA e cimento Portland. Foram utilizadas 32 raízes de 2 cães cujos canais radiculares permaneceram expostos ao meio oral por 90 dias para a indução de lesões periapicais, constatadas radiograficamente. Após este período, as raízes foram apicectomizadas a $3 \mathrm{~mm}$ do ápice radicular para confecção de retrocavidades com $3 \mathrm{~mm}$ de profundidade, utilizando-se pontas ultrasônicas diamantadas (ENAC). Os materiais retrobturadores foram inseridos até a superfície apicectomizada. Decorrridos 180 dias, os espécimes foram removidos e preparados para análise histomorfológica, com cortes de $6 \mu \mathrm{m}$ e coloração em HE. A análise dos resultados demonstrou não haver diferenças estatisticamente significantes entre os referidos materiais quando utilizados em retrobturações de dentes de cães portadores de lesões periapicais. Os autores concluíram que os materiais não diferiram entre si quando utilizados em obturações retrógradas, contudo, ressaltaram que, não se indica a utilização do cimento Portland em seres humanos em função de implicações éticas e jurídicas junto ao ministério de saúde, pois existem 
diferentes tipos de cimentos em função da adição de outros componentes que ainda não foram estudados. 


\subsection{MBPc}

O cimento endodôntico cirúrgico MBPc, é um cimento experimental desenvolvido na disciplina de Endodontia da Faculdade de Odontologia de Bauru - Universidade de São Paulo, pelos professores Ivaldo Gomes de Moraes e Alceu Berbert, fruto de uma linha de pesquisa iniciada em 1984 (MORAES ${ }^{86}$ ).

À base de resina epóxica, contendo em sua fórmula o hidróxido de cálcio, este cimento, foi desenvolvido para ser utilizado em obturações retrógradas (PAVAN $\left.{ }^{101}, 1999\right)$ e perfurações radiculares (SILVA NETO; MORAES ${ }^{126}$, 2003) como componente obturador.

Em 1999, PAVAN ${ }^{101}$ avaliou a infiltração marginal em obturações retrógradas realizadas com polímero de mamona, epóxico experimental (MBLc, anterior ao MBPc), cimento de óxido de zinco e eugenol reforçado (Super EBA) e ionômero de vidro (Fuji II LC). Utilizando 80 dentes anteriores humanos extraídos, previamente instrumentados e obturados, realizou-se a apicectomia com broca cilíndrica n ${ }^{0701}$ e o preparo de retrocavidades com o auxílio de brocas esféricas no2 de ponta ativa de $2 \mathrm{~mm}$. Os dentes foram distribuídos, aleatoriamente, em quatro grupos de 20 elementos cada, de acordo com os materiais retrobturadores utilizados. Os espécimes foram, então, impermeabilizados com duas camadas de Araldite e duas de esmalte de unhas e imersos em solução de azul de metileno a $2 \%$ e a $370 \mathrm{C}$. Decorridas 48 horas, os dentes foram seccionados no sentido longitudinal, expondo as retrobturações e avaliados quanto à infiltração do corante na interface dentina material retrobturador. Os valores obtidos por meio do programa SigmaScan revelaram que o polímero de mamona foi o material que permitiu menor infiltração seguido do cimento experimental MBLc, ionômero de vidro (Fuji II LC) e Super EBA. Os dados, quando submetidos à análise estatística, demonstraram diferenças apenas entre o polímero de mamona e o Super EBA. 
BRANDÃO ${ }^{26}$, também em 1999, realizou um trabalho, a partir de uma versão do cimento $\mathrm{MBPc}$, o cimento $\mathrm{MBP}$ destinado à obturação de canais, avaliando sua capacidade de escoamento, tempo de presa, radiopacidade, infiltração marginal apical, análise de pH e liberação de cálcio e comparando os dados encontrados ao cimento de óxido de zinco e eugenol, Sealer 26 e Sealer Plus.

Quando à capacidade de escoamento o cimento Sealer 26 apresentou os maiores valores de escoamento seguido do MBP, no entanto, os valores obtidos por todos os cimento estudados satisfizeram as normas da ISSO/DIS $6876^{14}$.

Quanto ao tempo de presa, BRANDÃO ${ }^{26}$ (1999) relatou que apenas o cimento Sealer Plus não sofreu influência da umidade ambiente e apresentou os menores tempos de presa inicial e final entre todos os materiais estudados. O cimento de óxido de zinco e eugenol foi o que apresentou maior tempo de presa final em ambiente com umidade, seguido pelo MBP, Sealer 26 e Sealer Plus.

Quanto à radiopacidade o cimento Sealer Plus foi o que apresentou melhores resultados, seguido pelo MBP, Sealer 26 e cimento de óxido de zinco e eugenol, contudo, não foram superiores à guta-percha. $\mathrm{O}$ autor também concluiu que todos os cimentos testados apresentaram valores superiores ao mínimo do equivalente a 3 milimetros de alumínio estabelecido pela norma ISO/DIS 6876.

Quanto à infiltração marginal apical o cimento experimental MBP apresentou os menores índices de infiltração, seguido pelo Sealer 26 e Sealer Plus. O autor ainda relatou que esses três cimentos foram superiores do ponto de vista estatístico quando comparados ao cimento de óxido de zinco e eugenol.

BRANDÃO $^{26}$ (1999) também avaliou os valores de $\mathrm{pH}$ do cimento MBP comparando com os cimentos de óxido de zinco e eugenol, 
Sealer 26 e Sealer Plus. O autor relatou que o cimento Sealer 26 apresentou os maiores valores de $\mathrm{pH}$ em todos os períodos estudados, sendo que aos 15 dias apresentou tendência à estabilização, enquanto que o cimento experimental MBP apresentou valores crescentes a partir de 72 horas, quase se igualando ao Sealer 26 no período de 30 dias. O autor concluiu que houve diferenças estatísticas entre os cimento estudados, em função do tempo.

Quanto à liberação de cálcio o cimento MBP apresentou os maiores valores de liberação deste íon nos períodos maiores de 15 e 30 dias. Entretanto, nos períodos mais curtos de 24 e 72 horas e 7 dias 0 cimento Sealer 26 apresentou valores mais altos. Ressaltou o autor que, também, no período de 24 horas o cimento Sealer Plus foi superior e que houve diferenças estatisticamente significante entre a liberação do íon cálcio de todos os cimentos, em função dos tempos.

BRANDÃO ${ }^{26}$ (1999) concluiu que todos os testes realizados, ou seja, a capacidade de escoamento, o tempo de presa, a radiopacidade, a infiltração marginal apical, a análise de $\mathrm{pH}$ e a liberação do íon cálcio demonstraram que $\mathrm{o}$ cimento $\mathrm{MBP}$ satisfaz às exigências da norma ISSO/DIS 6876.

Em 2003, SILVA NETO et al. ${ }^{126}$ avaliaram a capacidade seladora do MBPc comparando-o ao ProRoot MTA, MTA Angelus e Super EBA. Os autores simularam perfurações de furca em molares humanos extraídos e selaram-nas com um dos materiais associando ou não uma matriz de gesso Paris. Os espécimes, depois de imersos em Rodamina B a $0,2 \%$, foram avaliados quanto à infiltração sofrida na interface dente e material selador. O cimento experimental MBPc exibiu juntamente com o Super EBA os menores índices de infiltração sendo os dados estatisticamente significantes quando comparados aos do MTA Angelus e ProRoot MTA. Os autores também relataram que apesar da matriz de gesso Paris ter influenciado negativamente nos grupos do MBPc e Super EBA, 
ainda assim, quando foi empregada em associação ao MBPc, ele também foi superior.

SIQUEIRA, et al. ${ }^{127}$, em 2004, avaliaram a infiltração bacteriana de alguns cimentos utilizados como materiais retrobturadores e dentre eles o MBPc. Foram utilizados 92 dentes humanos unirradiculados extraídos, os quais tiveram as coroas removidas e os canais instrumentados. As raízes foram subdivididas em quatro grupos experimentais de 20 espécimes cada. Os 12 espécimes restantes formaram os grupos de controle positivo e negativo. Foi realizada a apicectomia dos $3 \mathrm{~mm}$ apicais, retrocavidades de $3 \mathrm{~mm}$ de profundidade por 1.5 de diâmetro foram preparadas e retrobturados com MTA ProRoot, MTA Ângelus, cimento portland e MBPc. No controle positivo não foi inserido nenhum material na retrocavidade, enquanto que o controle negativo teve a cavidade apical selada com araldite. Todos os espécimes foram inseridos em tubos eppendorf, fixados com araldite e mantidos em ambiente úmido por 15 dias. Após este período os conjuntos raízes e eppendorf foram esterilizadas em óxido de etileno, montados em frascos tipo penicilina contendo $4.5 \mathrm{ml}$ de caldo $\mathrm{BHI}$ e incubados a $37^{\circ} \mathrm{C}$ durante 4 dias para verificar a esterilidade do aparato. Decorrido este período foram inoculados $0,4 \mathrm{ml}$ da cultura de Enterococcus Faecalis ATCC 29212 (aproximadamente 10 UFC/ml) no interior dos canais instrumentados e os conjuntos armazenados em estufa a $37^{\circ} \mathrm{C}$ durante 50 dias. A constatação da turvação do meio de cultura, que era trocado semanalmente, correspondeu à infiltração bacteriana permitida pelo material retrobturador. O MBPc apresentou turvação do meio de cultura em apenas 1 espécime, assim como o MTA ProRoot, o MTA Ângelus e o cimento portland. Os dados foram submetidos à análise estatística e demonstraram não haver diferenças significativas quanto a infiltração bacteriana entre os quatro materiais testados. 
3 PROPOSIÇÃO 


\section{PROPOSIÇÃO}

A revisão da literatura demonstrou ser oportuna e viável a realização deste trabalho da maneira que foi exposta na introdução. Desta forma nos propusemos a:

3.1. Avaliar quantitativa e qualitativamente as reações teciduais frente ao cimento experimental MBPc, acondicionado em tubos de polietileno implantados em alvéolos dentários de ratos após extração, comparando-o com o cimento ProRoot MTA. 


\section{MATERIAL E MÉTODOS}




\section{MATERIAL E MÉTODOS}

\subsection{MATERIAL}

\subsubsection{ANIMAIS}

Para a realização deste trabalho foram utilizados 48 ratos machos (Rattus, norvegicus, albinus, Wistar), com idades aproximadas de 90 dias, pesando aproximadamente $350 \mathrm{~g}$ e provenientes do biotério da Faculdade de Odontologia de Bauru - Universidade de São Paulo. Os animais foram mantidos em ambiente com temperatura entre 22 e $24^{\circ} \mathrm{C}$ com ciclo de luz controlada (12 horas claro e 12 horas escuro) e em gaiolas coletivas, contendo quatro ratos por gaiola. No interior das gaiolas havia cama de serragem, a qual era trocada diariamente. Esses animais foram alimentados antes e durante todo o período experimental com ração sólida triturada e água "ad libitum", exceto nas primeiras 12 horas pré e pósoperatórias.

Previamente ao início do experimento, o projeto de pesquisa foi submetido à apreciação do Comitê de Ética no Ensino e Pesquisa em Animais (CEEPA - Processo $n^{\circ}$ 012/2003) e aprovado em 07/05/2003 (ANEXO 1).

\subsubsection{MATERIAIS RETROBTURADORES}

Foram empregados o cimento reparador ProRoot MTA e o cimento experimental MBPc descritos a seguir: 


\subsubsection{Cimento reparador ProRoot MTA':}

O cimento ProRoot MTA apresenta embalagem composta por dois envelopes contendo 1 grama de pó cada, e três recipientes contendo água destilada (Fig. 1).

A sua fórmula apresenta a seguinte composição:

Tabela 1 - Composição do cimento ProRoot MTA

\section{COMPONENTES}

PÓ:

Óxido de bismuto $\left(\mathrm{Bi}_{2} \mathrm{O}_{3}\right) \ldots \ldots \ldots \ldots \ldots \ldots . \ldots 20 \%$ em peso

Gesso $\left(\mathrm{CaSO}_{4}-2 \mathrm{H}_{2} \mathrm{O}\right) \ldots \ldots \ldots \ldots \ldots \ldots \ldots . . \ldots \ldots$ em peso

Cimento Portland............................ $\cong 75 \%$ em peso

- Silicato tricálcico $\left(3 \mathrm{CaO}-\mathrm{SiO}_{2}\right)$

- Silicato dicálcico $\left(2 \mathrm{CaO}-\mathrm{SiO}_{2}\right)$

- Aluminato tricálcico $\left(3 \mathrm{CaO}-\mathrm{Al}_{2} \mathrm{O}_{3}\right)$

- Aluminoferrato tetracálcico $\left(4 \mathrm{CaO}-\mathrm{Al}_{2} \mathrm{O}_{3}-\mathrm{Fe}_{2} \mathrm{O}_{3}\right)$

LÍQUIDO:

Água destilada

\footnotetext{
' ProRoot MTA - Dentsply - Tulsa Ltda.
} 
A proporção utilizada nos experimentos foi a recomendada pelo fabricante, uma parte de pó para uma de líquido. Após a mistura obteve-se um cimento arenoso e úmido.

O tempo de presa inicial, segundo o fabricante, é de 2 horas e 45 minutos e o final é de, aproximadamente, 4 horas. 


\subsubsection{Cimento experimental MBPc":}

O cimento experimental resinoso que contém hidróxido de cálcio, desenvolvido na disciplina de Endodontia, da Faculdade de Odontologia de Bauru - Universidade de São Paulo, pelos Profs. Drs. Ivaldo Gomes de Moraes e Alceu Berbert, apresenta embalagem contendo uma pasta base e uma pasta catalisadora (Fig. 2).

A sua fórmula apresenta a seguinte composição:

Tabela 2 - Composição do cimento MBPc

\section{COMPONENTES}

PASTA BASE:

- Hidróxido de cálcio

- Sulfato de bário

- Subnitrato de bismuto

- Resina epóxica

\section{PASTA CATALISADORA:}

- Sulfato de bário

- Subnitrato de bismuto

- Endurecedor para resina epóxica

- Poliol de poliuretana vegetal de mamona

\footnotetext{
"Disciplina de Endodontia - Faculdade de Odontologia de Bauru - USP.
} 
A proporção utilizada nos experimentos foi a recomendada pelos idealizadores, ou seja, três partes de pasta base para uma da pasta catalisadora. Após a mistura obteve-se um cimento plástico e consistente.

O tempo de presa inicial, segundo os idealizadores, é de 2 horas e 30 minutos e o final é de aproximadamente 4 horas. 


\subsubsection{TUBOS DE POLIETILENO}

Foram utilizados 48 tubos de polietileno" com 1,0mm de diâmetro interno, 1,6mm de diâmetro externo e 3,0mm de comprimento, os quais foram esterilizados em autoclave. Uma extremidade de cada tubo foi selada com guta-percha ${ }^{\mathrm{IV}}$ aquecida, numa extensão de $1 \mathrm{~mm}$. Os materiais, depois de manipulados segundo as especificações do fabricante e idealizadores, foram introduzidos na outra extremidade do tubo de polietileno, preenchendo os $2 \mathrm{~mm}$ restantes e ficando rente à superfície externa, exceto no grupo controle onde a extensão correspondente ao material retrobturador permaneceu vazia (Fig. 3).

\subsubsection{ANESTÉSICO}

Foram empregados como sedativo, Dopaser ${ }^{\mathrm{V}}$, à base de xilazina (relaxante muscular, analgésico e sedativo), na dosagem de 10mg por Kilograma de peso corporal .e como anestésico o Vetanarcol ${ }^{\mathrm{V}}$, à base de cloridrato de Ketamina a $5 \%$ na dosagem de $25 \mathrm{mg}$ por Kilograma de peso corporal (Fig. 4).

A conduta anestésica seguiu a tabela peso/dosagem utilizada pela disciplina de Endodontia da Faculdade de Odontologia de Araçatuba - UNESP, em experimentações animais (ANEXO 2).

\footnotetext{
III Abbott Lab. do Brasil Ltda., São Paulo, SP

IV Tanari Man Ind.

$\checkmark$ Calier S.A. - Barcelona, Espanha.

${ }^{\mathrm{V}}$ König S. A. - Avellaneda, Argentina.
} 
Figura 1 - Cimento reparador ProRoot MTA (Dentsply - Tulsa Dental)

A embalagem apresenta 2 envelopes contendo 1 grama de pó cada e três recipientes contendo água destilada.

Figura 2 - Cimento experimental MBPc (Faculdade de Odontologia de Bauru Universidade de São Paulo)

Cimento experimental resinoso com hidróxido de cálcio constituído por uma pasta base e uma pasta catalisadora.

Figura 3 - Tubo de polietileno (Abbott Lab. do Brasil Ltda., São Paulo, SP )

Esquema do tubo de polietileno implantado no alvéolo dentário com suas dimensões.

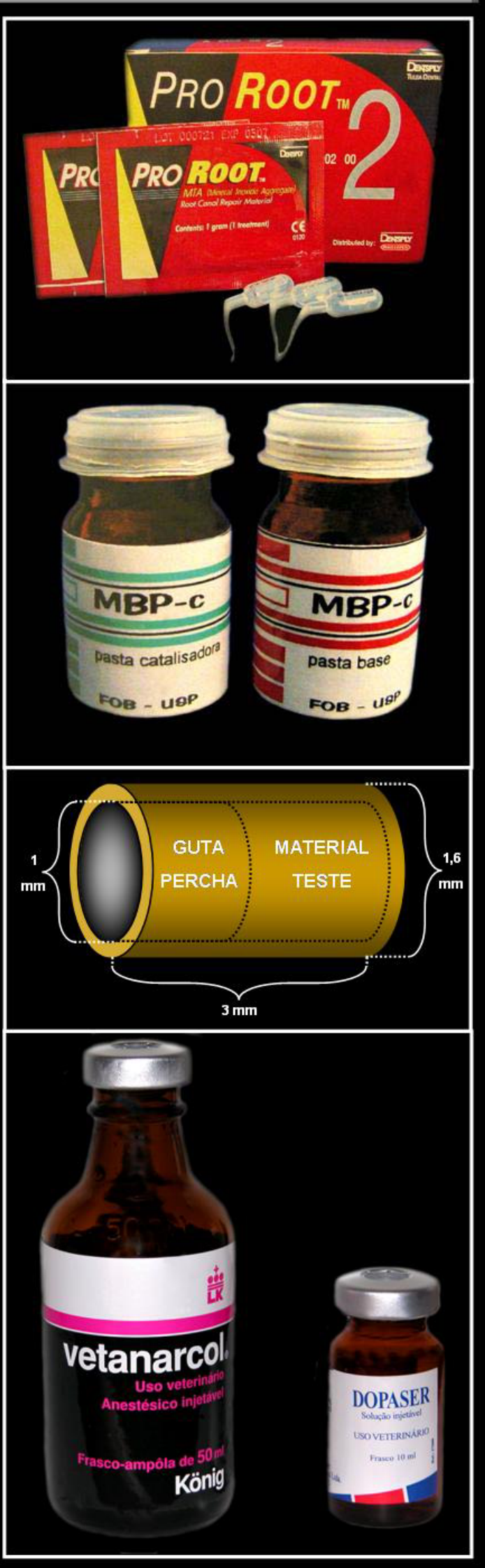

Figura 4 - Anestésico Vetanarcol (König S. A. - Avellaneda, Argentina) e sedativo Dopaser (Calier S.A. Barcelona, Espanha)

Anestésico à base de quetamina e relaxante muscular, analgésico e sedativo à base de xilazina. 


\subsection{MÉTODOS}

\subsubsection{PROCEDIMENTOS CIRÚRGICOS}

A) Para a realização das intervenções cirúrgicas os animais foram, inicialmente, pesados e, então, sedados com injeção intramuscular de Dopaser, e em seguida anestesiados com Vetanarcol. O período de trabalho com cada animal não ultrapassou 5 minutos e, desta maneira, não houve necessidade de complementação anestésica no decorrer da experimentação.

B) Após a anestesia realizou-se a anti-sepsia com gaze embebida em solução de $\mathrm{PVPI}^{\mathrm{VII}}$ na porção anterior da maxila, externamente e, depois, internamente em toda a região próxima ao alvéolo dentário direito da maxila, incluindo dentes e tecidos moles pelo lado vestibular e palatino.

C) Com o auxílio de um esculpidor tipo Hollemback ${ }^{V I I I}$ realizou-se a sindesmotomia ao redor de todo o dente de forma a preservar a margem gengival permitindo, posteriormente, uma síntese ou sutura adequada. Utilizando-se de um instrumental especial (OKAMOTO; $\mathrm{RUSSO}^{96}$ ), cedido gentilmente pelo Prof. Dr. Tetuo Okamoto da Faculdade de Odontologia de Araçatuba - UNESP, que foi introduzido entre o dente e a cortical óssea alveolar, luxou-se o alvéolo dentário (Fig. 5) e, de posse de outro instrumento adaptado para este fim (OKAMOTO; RUSSO ${ }^{96}$ ), o dente foi extraído (Fig. 6). Neste momento cirúrgico foi realizada a contenção da hemorragia alveolar com o auxílio de compressas de gaze.

D) Os tubos de polietileno, com uma de suas extremidades previamente selada com guta-percha, tiveram a outra extremidade preenchida com os materiais retrobturadores, ficando estes rente à sua superfície externa.

\footnotetext{
VII Povidini tópico - Johnson \& Johnson S./A.

VIII Hollemback \# 3.
} 
E) Um tubo de polietileno foi introduzido em cada alvéolo, de maneira que, a extremidade contendo 0 material retrobturador permanecesse voltada para o fundo do alvéolo. No momento da implantação foi utilizada uma pinça reta para a inserção do tubo no primeiro terço alveolar (Fig. 7). O tubo, uma vez dentro do alvéolo, foi levado até o terço médio do mesmo com o auxílio de um instrumento adaptado à curvatura e diâmetro do alvéolo (Fig. 8).

F) Após a implantação dos tubos de polietileno, procedeu-se de imediato a aproximação das margens gengivais e sua síntese com pontos simples, realizada com fios de seda $4.0^{\mathrm{IX}}$, montados em agulha atraumática. Procurou-se, neste momento, coaptar bem as margens gengivais evitando a expulsão espontânea dos tubos de polietileno.

$\overline{\mathrm{IX}}$ Ethicon Johnson \& Johnson Ind. Com. Ltda. 
FIGURA 5 - Luxação do alvéolo

Aspecto cirúrgico visualizado no momento da inserção de instrumental especial entre o dente e a cortical óssea alveolar possibilitando a luxação do alvéolo.

FIGURA 6 - Extração do incisivo superior direito Aspecto cirúrgico visualizado no momento da extração dentária. Notar instrumento especial adaptado ao colo dentário utilizado para a extração do incisivo superior direito.

FIGURA 7 - Implantação do tubo de polietileno

Aspecto cirúrgico visualizado no momento da implantação do tubo de polietileno, contendo o material teste, no interior do alvéolo dentário realizado com auxílio de pinça reta.

FIGURA 8 - Introdução do tubo de polietileno

Aspecto cirúrgico visualizado no momento da introdução do tubo de polietileno para o terço médio do alvéolo com auxílio de instrumento especial adaptado.

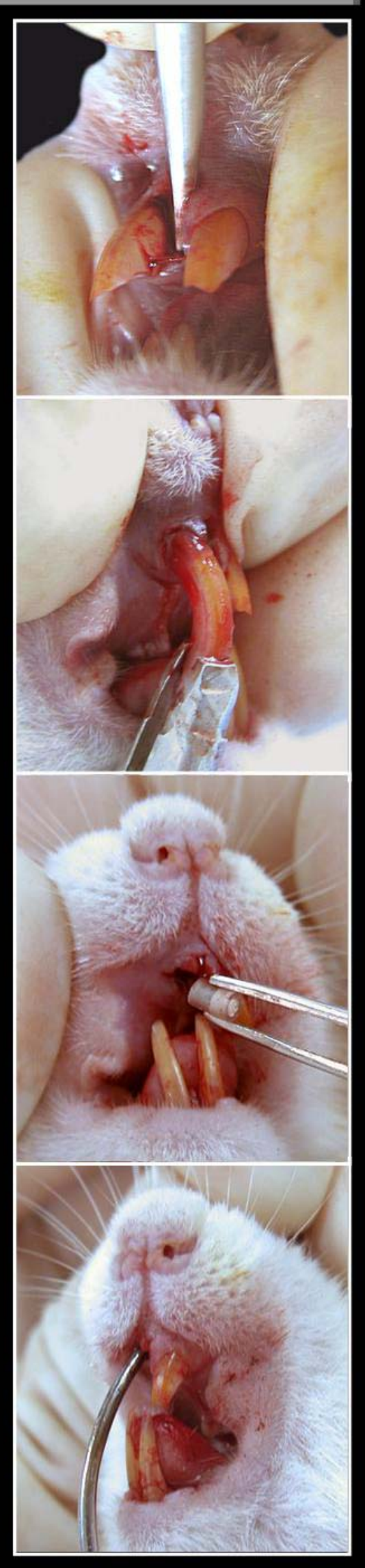




\subsubsection{GRUPOS EXPERIMENTAIS E CONTROLE}

De acordo com os materiais e tempos pós-operatórios os 48 ratos foram divididos em 3 grupos, sendo 2 experimentais e 1 controle. Cada grupos experimental foi composto de 18 ratos, sendo 6 animais para cada tempo pós-operatório. Já o grupo controle foi composto de 12 espécimes, sendo 4 para cada período, distribuídos conforme a tabela 3:

Tabela 3 - Distribuição dos materiais retrobturadores em grupos experimentais por períodos pós-operatórios e número de espécimes.

\begin{tabular}{c|c|c|c|c}
\hline \multirow{2}{*}{ GRUPOS } & \multirow{2}{*}{ MATERIAIS } & \multicolumn{3}{|c}{ PERÍODO I NÚMERO DE ESPÉCIMES } \\
\cline { 2 - 5 } & & 7 DIAS & 15 DIAS & 30 DIAS \\
\hline I - Controle & Vazio & 4 & 4 & 4 \\
\hline II - Experimental & ProRoot MTA & 6 & 6 & 6 \\
\hline III - Experimental & MBPc & 6 & 6 & 6 \\
\hline
\end{tabular}

- Grupo I: Controle: Tubo de polietileno vazio;

- Grupo II: Tubo de polietileno preenchido com o cimento ProRoot MTA;

- Grupo III: Tubo de polietileno preenchido com o cimento experimental $\mathrm{MBP}_{\mathrm{C}}$.

O grupo controle, da mesma forma que os demais grupos, teve uma das extremidades de cada tubo, selada com guta-percha. No entanto, toda a extensão do tubo correspondente ao material retrobturador ficou vazia e permaneceu voltada para o fundo do alvéolo.

A guta-percha empregada neste procedimento teve 0 propósito de vedar uma das extremidades do tubo procurando-se evitar que os materiais sofressem deslocamento no momento da introdução do tubo. 
Essa extremidade selada com guta-percha também serviu de anteparo para se impulsionar e colocar o tubo em posição no alvéolo.

Os tubos de polietileno foram preenchidos com os materiais retrobturadores imediatamente antes do implante, evitando que ocorresse a presa dos materiais anteriormente à sua implantação.

Os espécimes que tiveram os tubos introduzidos muito profundamente e ficaram próximos ao fundo do alvéolo foram descartados e novos procedimentos cirúrgicos foram realizados até que se completasse 0 número de espécimes suficientes para a análise. 


\subsubsection{OBTENÇÃO DAS PEÇAS}

A) De acordo com os grupos, os animais foram mortos aos 7, 15 e 30 dias, por meio de uma dose excessiva de cloridrato de ketamina (anestésico) injetada no coração. Após a morte, foi removida toda a pele correspondente à face direita do animal e com dois cortes com tesoura, situados no ângulo da boca, separou-se a mandíbula da maxila (Fig. 9).

B) Com o auxílio de uma lâmina intercambiável ${ }^{x} n^{0} 15$, montada em cabo de bisturi, realizou-se uma incisão em profundidade no palato do animal ao nível de plano sagital mediano acompanhando a sutura intermaxilar separando a maxila direita da esquerda (Fig. 10).

C) Separadas as maxilas e, empregando-se novamente uma tesoura, foi realizado um outro corte de modo a tangenciar a face distal dos molares superiores direitos, possibilitando a obtenção da hemimaxila direita contendo o alvéolo dentário com o tubo implantado (Fig. 11).

Anteriormente à fixação foi realizada a remoção de todo excesso de tecido muscular da parte externa da peça e, internamente, foi feita a limpeza preservando o septo nasal (Fig. 12 e 13).

$\mathrm{Na}$ seqüência, as peças foram radiografadas, procurando identificar alvéolos que por acaso ou devido a processos infecciosos, pudessem ter tido os tubos expulsos. Realizado o exame radiográfico verificou-se que nenhum dos tubos de polietileno havia sido expulso durante o período experimental.

\footnotetext{
${ }^{\mathrm{x}} \mathrm{B}-\mathrm{D}-$ Becton Dickinson Indústria Cirúrgica Ltda.
} 


\begin{abstract}
FIGURA 9 - Separação da maxila da mandíbula

Aspecto cirúrgico visualizado após dois corte realizados com tesoura reta junto aos ângulos da boca do animal, o que possibilitou a separação da maxila da mandibula.
\end{abstract}

FIGURA 10 - Separação das maxilas

Aspecto cirúrgico visualizado no momento da incisão realizada ao nivel do plano sagital acompanhando a sutura intermaxilar, que promoveu a separação das maxilas.

FIGURA 11 - Obtenção da hemi-maxila direita

Aspecto cirúrgico visualizado no momento do corte realizado com tesoura reta tangenciando a face distal dos molares, que possibilitou a obtenção da hemi-maxila.

FIGURA 12 - Hemi-maxila direita

Aspecto da hemi-maxila direita após limpeza contendo o alvéolo com o tubo de polietileno implantado

FIGURA 13 - Hemi-maxila direta sob visão lateral

Aspecto lateral da hemi-maxila direita após limpeza contendo - alvéolo com 0 tubo de polietileno implantado

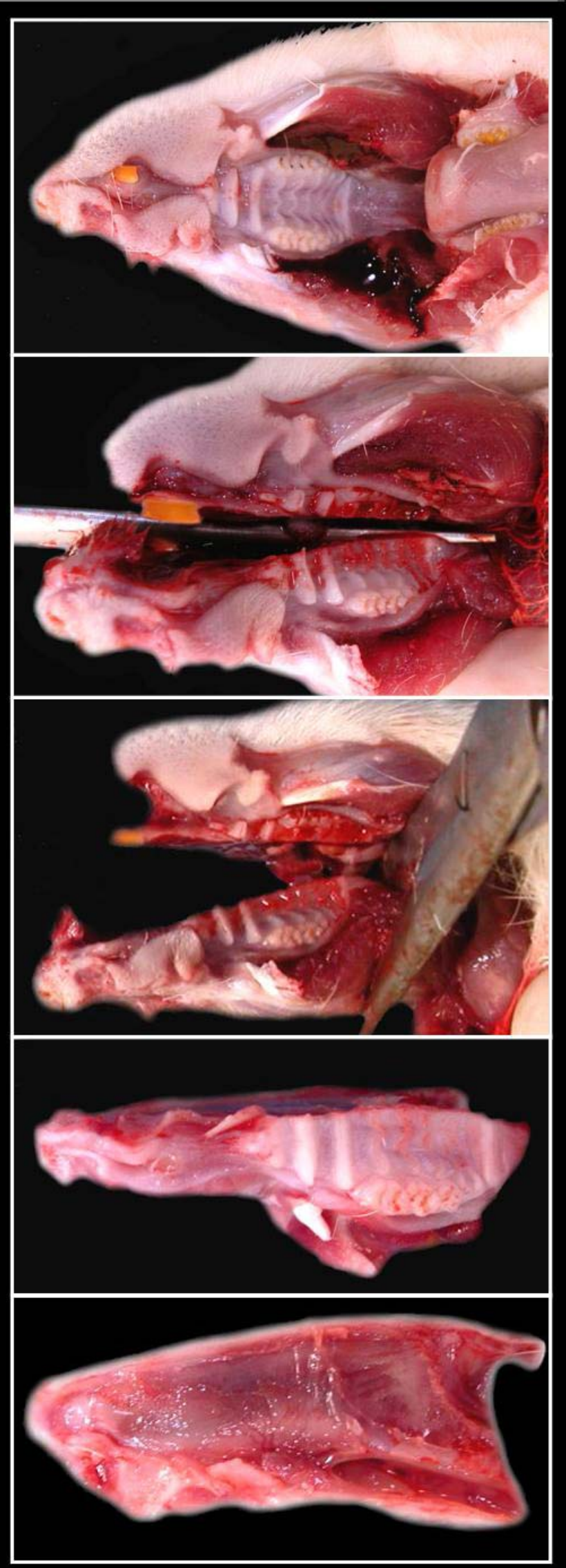




\subsubsection{PROCESSAMENTO LABORATORIAL}

A) As hemimaxilas, assim obtidas, foram colocadas imediatamente em frascos individuais devidamente identificados, contendo solução de formalina a $10 \%^{\times 1}$, tamponada com $\mathrm{pH}$ neutro, durante as primeiras 48 horas e lavadas em água corrente por um período de 5 horas para a remoção de toda solução de fixação.

B) Após a fixação as peças foram desmineralizadas em solução de EDTA a 18\% ${ }^{\mathrm{XII}}$. Decorridas aproximadamente 200 horas, considerou-se finalizado o processo de desmineralização. Isto era controlado quando uma agulha fina podia ser introduzida no espécime sem qualquer tipo de resistência. Neste momento, as peças apresentavam-se com consistência borrachóide, sem resistência ao corte pela navalha.

C) Posteriormente, as hemimaxilas foram lavadas em água corrente, desidratadas em álcool, diafanizadas em xilol e incluídas em parafina. A orientação no momento da inclusão permitiu a realização de cortes teciduais do alvéolo em seu sentido longitudinal (Fig. 17).

D) Uma vez incluídas, as peças sofreram cortes semiseriados, com $6 \mu \mathrm{m}$ de espessura, realizados em micrótomo ${ }^{\mathrm{XII}}$. Para cada espécime em estudo, aproveitaram-se os cortes teciduais que evidenciavam o lume do tubo de polietileno no seu longo eixo, contendo ou não os materiais retrobturadores (Fig. 18).

E) Para cada espécime, 10 lâminas com 5 cortes teciduais cada, foram preparadas e coradas com Hematoxilina e Eosina segundo LILLIE $^{79}$, 1954. Foi também realizada a coloração de Brown \& Brenn (BOHORQUEZ et al. ${ }^{23}$ ) em outras duas lâminas de cada espécime. Todos

\footnotetext{
${ }^{\mathrm{XI}}$ Laboratório de Endodontia - Faculdade de Odontologia de Araçatuba - UNESP

XII Laboratório de Endodontia - Faculdade de Odontologia de Araçatuba - UNESP
} 
os cortes teciduais foram analisados microscopicamente, tabulados e submetidos à análise estatística.

XIII Leica (RM 2045). 
FIGURA 14 - Aspecto lateral do crânio

Anatomia do crânio do rato visualizado lateralmente após processo de maceração

FIGURA 15 - Corte sagital mediano do crânio

Anatomia do crânio do rato visualizado após a remoção do septo nasal

FIGURA 16 - Hemi-maxila direita sob visão lateral

Visão macroscópica do espécime obtido após cirurgia de remoção

FIGURA 17 - Corte longitudinal do alvéolo

Aspecto da alvéolo e estruturas anexas após inclusão em parafina. Notar a presença do tubo de polietileno no interior do alvéolo

FIGURA 18 - Desenho esquemático do corte tecidual

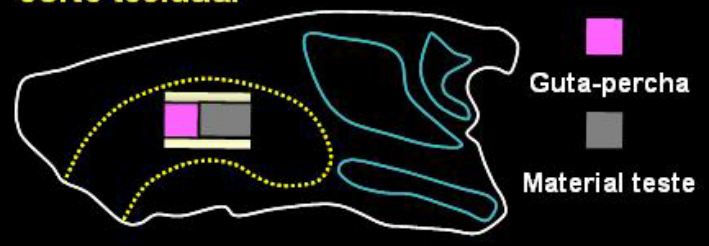

FIGURA 19 - Aspecto radiográfico dorsal da cabeça do rato

Tomada radiográfica axial empregada para a verificação da presença do tubo no interior do alvéolo. Em destaque, radiografia após extração dentária possibilitando a visualização do alvéolo dentário vazio (A) e após a implantação do tubo de polietileno com os materiais testados (B).
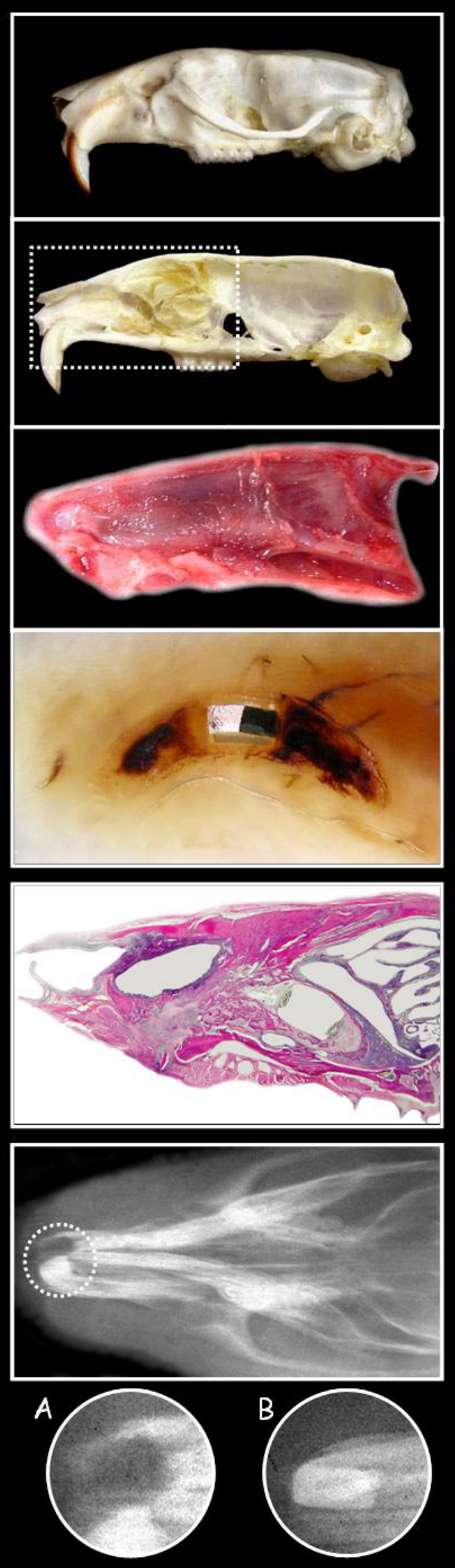


\subsubsection{FORMA DE ANÁLISE DOS RESULTADOS}

A análise microscópica foi realizada com auxílio de um microscópio binocular ${ }^{\mathrm{XIV}}$ e os resultados foram expostos por meio de duas análises, sendo uma descritiva e outra quantitativa, referentes a cada grupo experimental e tempo pós-operatório.

\subsubsection{ANÁLISE DESCRITIVA}

A análise microscópica descritiva do processo de reparo alveolar e principalmente da reação tecidual proveniente dos materiais retrobturadores consistiu na descrição dos fenômenos observados microscopicamente nos cortes teciduais representativos de cada grupo e tempo pós-operatório, procurando caracterizá-los globalmente, em função das variáveis experimentais. Para maior segurança desta análise e para auxiliar na análise quantitativa foi elaborada uma tabela onde foram registrados os fenômenos presentes em cada corte tecidual.

As características do infiltrado inflamatório puderam ser avaliadas por meio da observação dos tipos celulares presentes, de sua distribuição e dos aspectos referentes ao citoplasma e núcleo. As características do exudato puderam ser avaliadas pela presença das áreas de abscedeção quando da presença de microabscessos ou abscessos e, ainda, quanto à presença de áreas com fibrina, próximo ao material.

Os fenômenos vasculares foram classificados em edema, hiperemia, hemorragia e trombose, e os fenômenos reparatórios na organização do fibrosamento. As características do material foram descritas de acordo com sua morfologia em homogêneo, granular, cristalizado, fibroso ou quando mais de uma característica estivesse presente. Os materiais também foram avaliados quanto à possibilidade de serem fagocitáveis e

XIV Olympus CBA 
quanto às suas localizações em relação ao tubo de polietileno, classificandoos em aquém, ao nível ou além do tubo.

O tecido mineralizado, quando presente, foi registrado quanto à sua localização, assim como, a neoformação óssea.

Todos os fenômenos observados foram marcados com um $X$ nos locais correspondentes ao item avaliado. O preenchimento dessa tabela (4), abaixo exemplificada, possibilitou a realização de uma descrição mais precisa dos grupos experimentais. 
Tabela 4 - Tabela utilizada para a distribuição dos dados presentes nos grupos experimentais por períodos e número de espécimes.

\begin{tabular}{|c|c|c|c|c|c|c|c|c|c|c|}
\hline \multicolumn{11}{|c|}{ GRUPO } \\
\hline \multicolumn{11}{|c|}{ PERÍODO EXPERIMENTAL } \\
\hline \multicolumn{5}{|c|}{ ESPÉCIMES } & 1 & 2 & 3 & 4 & 5 & 6 \\
\hline \multirow{27}{*}{$\begin{array}{c}\text { Infiltrado } \\
\text { inflamatório: } \\
\text { características }\end{array}$} & \multirow{6}{*}{ 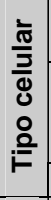 } & \multirow{2}{*}{\multicolumn{2}{|c|}{ PMN }} & neutrófilo & & & & & & \\
\hline & & & & eosinófilo & & & & & & \\
\hline & & \multirow{3}{*}{\multicolumn{2}{|c|}{$\mathrm{MN}$}} & macrófago & & & & & & \\
\hline & & & & linfócito & & & & & & \\
\hline & & & & plasmócito & & & & & & \\
\hline & & \multicolumn{3}{|c|}{ CGMLS } & & & & & & \\
\hline & \multirow{8}{*}{ 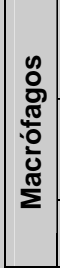 } & \multirow{3}{*}{\multicolumn{2}{|c|}{ distribuição }} & ao acaso & & & & & & \\
\hline & & & & periférica & & & & & & \\
\hline & & & & à distância & & & & & & \\
\hline & & \multirow{3}{*}{\multicolumn{2}{|c|}{ citoplasma }} & homogêneo & & & & & & \\
\hline & & & & vacuolado & & & & & & \\
\hline & & & & com partículas & & & & & & \\
\hline & & \multirow{2}{*}{\multicolumn{2}{|c|}{ núcleo }} & normal & & & & & & \\
\hline & & & & alterado & & & & & & \\
\hline & ฮิ & \multirow{3}{*}{\multicolumn{2}{|c|}{ distribuição }} & ao acaso & & & & & & \\
\hline & হ్రి & & & periférica & & & & & & \\
\hline & $\frac{0}{0}$ & & & à distância & & & & & & \\
\hline & อ & $\widetilde{\widetilde{\sigma}}$ & \multirow{3}{*}{ aspecto } & homogêneo & & & & & & \\
\hline & $\Phi$ & $\frac{\varepsilon}{\omega}$ & & vacuolado & & & & & & \\
\hline & $\overrightarrow{\mathbf{E}}$ & $\frac{\pi}{2}$ & & com partículas & & & & & & \\
\hline & $\bar{g}$ &. & \multirow{2}{*}{ contorno } & regular & & & & & & \\
\hline & Ё. & & & irregular & & & & & & \\
\hline & 뜬 & \multirow{5}{*}{ 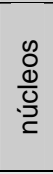 } & & imero & & & & & & \\
\hline & б & & distribuição & ao acaso & & & & & & \\
\hline & 气ี & & 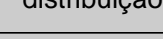 & periféricos & & & & & & \\
\hline & $\overline{\frac{2}{\omega}}$ & & tipo & Langhans & & & & & & \\
\hline & & & & corpo estranho & & & & & & \\
\hline Exudato: & & área & s de & icroabscessos & & & & & & \\
\hline características & & bsce & deção & abscessos & & & & & & \\
\hline Calacteristicas & & & & & & & & & & \\
\hline & & & ed & & & & & & & \\
\hline Fenômenos & & & hipe & & & & & & & \\
\hline vasculares & & & hemc & gia & & & & & & \\
\hline & & & trom & & & & & & & \\
\hline Fenômenos & & & ganização do & ao acaso & & & & & & \\
\hline reparatórios & & & ibrosamento & capsular & & & & & & \\
\hline & & & homo & 1eo & & & & & & \\
\hline & & & & granular & & & & & & \\
\hline & & & o homogênec & c/ cristais & & & & & & \\
\hline & & & & fibroso & & & & & & \\
\hline características & & & acão em relac & aquém & & & & & & \\
\hline & & adil & ertura do tubc & no nível & & & & & & \\
\hline & & & & além & & & & & & \\
\hline & & & Fagocitável & $\operatorname{sim}$ & & & & & & \\
\hline & & & ragucitavel & não & & & & & & \\
\hline & & & & & & & & & & \\
\hline Tecido & & & pró & & & & & & & \\
\hline mineralizado & & & à dis & cia & & & & & & \\
\hline & & & aus & & & & & & & \\
\hline & & & & & & & & & & \\
\hline Tecidn óccen & & & pró & & & & & & & \\
\hline reciuo usses & & & à dis & cia & & & & & & \\
\hline & & & aus & & & & & & & \\
\hline
\end{tabular}




\subsubsection{ANÁLISES QUANTITATIVAS}

A análise quantitativa foi realizada por meio da atribuição de escores, graduando as magnitudes dos fenômenos microscópicos observados separadamente. Foi realizada a determinação dos tipos celulares presentes e a avaliação das condições microscópicas das estruturas examinadas, em itens distintos atribuindo, posteriormente, magnitudes registradas sob a forma de escores de 1 a 4, possibilitando, dessa maneira, dados para uma análise estatística posterior.

Procurou-se, neste experimento, avaliar por meio de escores os aspectos referentes ao infiltrado inflamatório levando-se em consideração sua intensidade e extensão. Avaliou-se, também, a densidade de fibroblastos jovens e a densidade angioblástica da região próxima aos materiais ou à luz do tubo de polietileno. A densidade do fibrosamento, caracterizada pela proporção do número de células presentes e da quantidade de fibras foi outro aspecto registrado por meio de escores. Por fim, a deposição de tecido mineralizado e a neoformação de tecido ósseo foram, também, relacionadas nessa análise quantitativa. Empregou-se, também, uma tabela (5) previamente elaborada para a marcação dos escores atribuídos a cada item, conforme segue:

Tabela 5 - Tabela utilizada para a distribuição dos escores atribuídos aos grupos experimentais de acordo com os critérios estabelecidos, separados por períodos e número de espécimes.

\begin{tabular}{|c|c|c|c|c|c|c|c|c}
\hline GRUPOS /ESPÉCIMES & 1 & 2 & 3 & 4 & 5 & 6 & MÉDIAS \\
\hline CONTROLE & & & & & & & \\
\hline MTA & & & & & & & \\
\hline MBPC & & & & & & & \\
\hline
\end{tabular}


Desta forma, para a avaliação da resposta tecidual frente aos materiais retrobturadores estudados, foram estabelecidos os seguintes critérios para a atribuição dos escores:

\subsection{CRITÉRIO INFILTRADO INFLAMATÓRIO}

O infiltrado inflamatório foi avaliado quanto à sua intensidade, composição, tipo celular e sua distribuição em relação ao material ou à luz do tubo. Levou-se em consideração a tabela descritiva preenchida previamente, referente a cada grupo experimental e tempo pósoperatório, observados em cortes representativos e classificados nos seguintes escores (Fig. 20):

1 - Ausente: representa ausência ou presença insignificante de infiltrado inflamatório;

2 - Discreto: infiltrado inflamatório apenas frontal e junto ao material retrobturador ou à luz do tubo, apresentando pequena quantidade de células inflamatórias;

3 - Moderado: infiltrado inflamatório atingindo pequena área além do material ou à luz do tubo, apresentando moderada quantidade de células inflamatórias;

4 - Severo: infiltrado inflamatório atingindo extensa área além do material ou à luz do tubo, apresentando grande quantidade de células inflamatórias. 


\subsection{CRITÉRIO DENSIDADE DE FIBROBLASTOS JOVENS:}

A magnitude deste item foi estabelecida em função da quantidade de células fibroblásticas jovens em relação à proporção de fibras colágenas presentes nas proximidades do material ou da abertura do tubo de polietileno, em cortes representativos, classificadas nos seguintes escores:

1 - Ausente: representa ausência de células fibroblásticas jovens e grande quantidade de fibras colágenas;

2 - Baixa: representa baixa quantidade de células fibroblásticas jovens e grande quantidade de fibras colágenas;

3 - Média: representa média quantidade de células fibroblásticas jovens e média quantidade de fibras colágenas;

4 - Alta: representa alta quantidade de células fibroblásticas jovens e ausência de fibras colágenas. 


\subsection{CRITÉRIO DENSIDADE ANGIOBLÁSTICA:}

A magnitude deste item foi estabelecida em função da quantidade de vasos sangüíneos neoformados, caracterizados pela presença de angioblastos jovens organizando-se em capilares, em relação à proporção de fibras colágenas presentes nas proximidades do material ou da abertura do tubo, em cortes representativos, classificadas nos seguintes escores:

1 - Ausente: representa ausência de vasos sangüíneos neoformados e presença de tecido conjuntivo maduro com alta quantidade de fibras colágenas;

2 - Baixa: representa baixa quantidade de vasos sangüíneos neoformados e presença de tecido conjuntivo maduro com alta quantidade de fibras colágenas;

3 - Média: representa média quantidade de vasos sangüíneos neoformados e presença de tecido conjuntivo em maturação com média quantidade de fibras colágenas;

4 - Alta: representa alta quantidade de vasos sangüíneos neoformados e presença de tecido de granulação com ausência de fibras colágenas; 


\subsection{CRITÉRIO DENSIDADE DO FIBROSAMENTO:}

A magnitude deste item foi estabelecida em função da proporção de fibras colágenas em relação à quantidade de células presentes nas proximidades do material ou da abertura do tubo de polietileno, em cortes representativos, classificadas nos seguintes escores:

1 - Alta: representa grande quantidade de fibras e pouca quantidade de células;

2 - Média: representa média quantidade de fibras e média quantidade de células;

3 - Baixa: representa baixa quantidade de fibras e alta quantidade de células;

4 - Ausente: representa ausência de fibras e presença de células. 


\subsection{CRITÉRIO PRESENÇA E LOCALIZAÇÃO DA DEPOSIÇÃO DE TECIDO MINERALIZADO:}

A magnitude deste item foi estabelecida em função da presença ou ausência de tecido mineralizado localizado junto, próximo ou distante do material, em cortes representativos, classificados nos seguintes escores (Fig. 21):

1 - Junto: representa presença de tecido mineralizado junto ao material retrobturador;

2 - Próximo: representa presença de tecido mineralizado situado na região intermediária entre o material e o fundo do alvéolo;

3 - Distante: representa presença de tecido mineralizado situado próximo ao fundo do alvéolo;

4 - Ausente: representa ausência de tecido mineralizado junto, próximo ou à distância do material retrobturador. 


\subsection{CRITÉRIO PRESENÇA E LOCALIZAÇÃO DA DEPOSIÇÃO DE TECIDO ÓSSEO:}

A magnitude deste item foi estabelecida em função da presença ou ausência do tecido ósseo, localizado junto ao material, próximo ou distante dele, e ainda, quanto à presença de células como osteócitos, osteoblastos e osteoclastos, observados em cortes representativos e classificados nos seguintes escores (Fig. 22):

1 - Junto: representa presença de tecido ósseo junto ao material retrobturador ou à luz do tubo;

2 - Próximo: representa presença de tecido ósseo situado na região intermediária entre o material ou à luz do tubo e o fundo do alvéolo;

3 - Distante: representa presença de tecido ósseo situado próximo ao fundo do alvéolo;

4 - Ausente: representa ausência de tecido ósseo junto, próximo ou à distância do material retrobturador.

Eventualmente, nas proximidades da abertura do tubo ou material retrobturador, o tecido ósseo, bem como, alguns desses tipos celulares estavam ausentes ou desorganizados. 
FIGURA 20 - Representação esquemática dos escores atribuídos ao infiltrado inflamatório

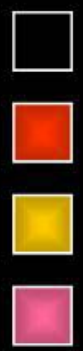

Escore 1 - Ausente

Escore 2 - Discreto

Escore 3 - Moderado

Escore 4 - Severo

FIGURA 21 - Representação esquemática dos escores atribuídos à presença e à localização da deposição de tecido mineralizado

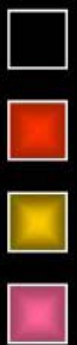

Escore 1 - Junto

Escore 2 - Próximo

Escore 3 - Distante

Escore 4 - Ausente

FIGURA 22 - Representação esquemática dos escores atribuídos à presença e à localização da deposição de tecido ósseo

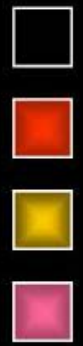

Escore 1 - Junto

Escore 2 - Próximo

Escore 3 - Distante

Escore 4 - Ausente
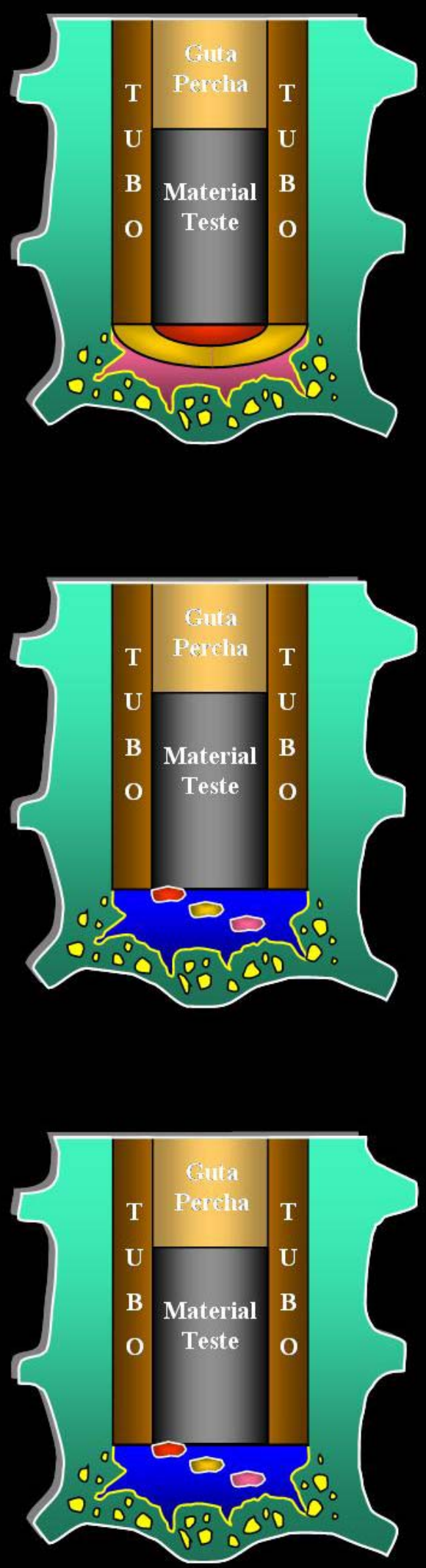


\subsubsection{ANÁLISE ESTATÍSTICA}

A avaliação microscópica dos cortes teciduais mais representativos de cada grupo e tempo pós-operatório foi efetuada por dois observadores e os dados encontrados, foram submetidos ao índice Kappa (LANDIS; $\mathrm{KOCH}^{74}$, 1977) para analisar a confiabilidade das leituras realizadas. Os valores obtidos que não satisfizeram os critérios dos níveis de concordância de coeficiente Kappa foram repetidos em uma segunda análise realizada pelos dois observadores, em conjunto, chegando-se a um consenso.

De posse dos valores finais obtidos na forma de escores foi realizado o teste não paramétrico de Kruskal-Wallis (SIEGEL et al. ${ }^{126}$, 1956) quando da comparação entre os 3 grupos. Este teste, também foi aplicado para cada um dos critérios de análise microscópica observados, individualmente, 1 a 1 . Quando o teste de Kruskal-Wallis demonstrou haver diferença entre os grupos aplicou-se, então, o teste de Dunn, para comparar individualmente a relação entre os grupos.

Empregou-se, também, na análise estatística o Teste $U$ de Mann-Whitney para avaliar comparativamente, os dois grupos experimentais (MTA e MBPc), levando-se em consideração todos os critérios em conjunto e também individualmente 1 a 1.

Para todos os teste empregados foi considerado o nível de significância de 5\% $(p<0,05)$. 
5 RESULTADOS 


\section{RESULTADOS}

\subsection{ANÁLISE DESCRITIVA}

Os resultados da análise microscópica descritiva dos cortes longitudinais semi-seriados dos alvéolos dentários representativos de cada grupo experimental, serão apresentados agrupados de acordo com os tempos pós-operatórios, em função das ocorrências observadas junto ao terço médio e apical dos alvéolos nos diferentes grupos. 


\section{GRUPO I - CONTROLE - TUBO VAZIO - 7 DIAS}

Imediatamente junto à abertura do tubo de polietileno e em seu interior, observou-se área ocupada por tecido de granulação neoformado, densamente organizado, com discreto infiltrado inflamatório, presença de fibroblastos jovens, alguns macrófagos e linfócitos (Fig. 23 $A, B, F)$. Esse tecido invaginado tornou-se menos organizado à medida que se adentrou, mais profundamente, no espaço vazio e, caracterizou-se, por áreas de infiltrado inflamatório agudo, com células em necrose, que apresentaram picnose e cariorrexe. Nas áreas de interface entre o tecido conjuntivo e o tubo, notou-se, uma celularidade aumentada, quando comparada à região mais central do tecido invaginado. Este aumento celular foi composto, predominantemente, por macrófagos e células gigantes multinucleadas inflamatórias (Fig. 23 F).

Num dos espécimes observou-se restos da papila dentária (tecidos odontogênicos), próximos à abertura do tubo, que se interpõem entre o fundo do alvéolo e a resposta tecidual ao tubo de polietileno (Fig. 23 A). Notou-se, neste caso, avançado estádio organizacional com a presença de odontoblastos depositando dentina. Subjacente, observou-se a matriz adamantina depositada pelos ameloblastos (estimulação recíproca), (Fig. 23 E).

Mais em direção ao fundo do alvéolo, notou-se a presença do tecido conjuntivo fibroso densamente organizado, caracterizado por apresentar menor população celular (Fig. 23 D). Em alguns pontos observou-se coágulo remanescente (Fig. 23 A), ainda desorganizado, exibindo alguns macrófagos em seu interior. 
Quanto aos tipos celulares, foi observado, em todos os espécimes, a presença de eosinófilos, macrófagos, linfócitos e células gigantes multinucleadas inflamatórias. Neutrófilos e plasmócitos estavam presentes em apenas metade dos espécimes.

No que se refere à localização dos macrófagos, observouse, distribuição ao acaso e à distância, em metade dos espécimes, e distribuição periférica em todos os espécimes. Os citoplasmas apresentaram-se homogêneos e os núcleos normais.

Em relação às células gigantes multinucleadas inflamatórias, observou-se, em todos os espécimes, distribuição periférica, citoplasma homogêneo com contorno irregular e núcleos distribuídos ao acaso.

Quanto às características do exudato pode-se observar microabscessos e presença de fibrina em todos os espécimes.

Quanto aos fenômenos vasculares observou-se apenas hiperemia em todos os espécimes.

Em relação aos fenômenos reparatórios, observou-se, na organização do fibrosamento, apenas características capsulares.

Quanto à neoformação óssea, observou-se que a mesma não estava presente em nenhum dos espécimes.

Todos esses eventos microscópicos observados estão dispostos na tabela 6 . 
Tabela 6 - Grupo Controle - 7 dias - Descrição atribuída aos eventos microscópicos observados nos espécimes analisados

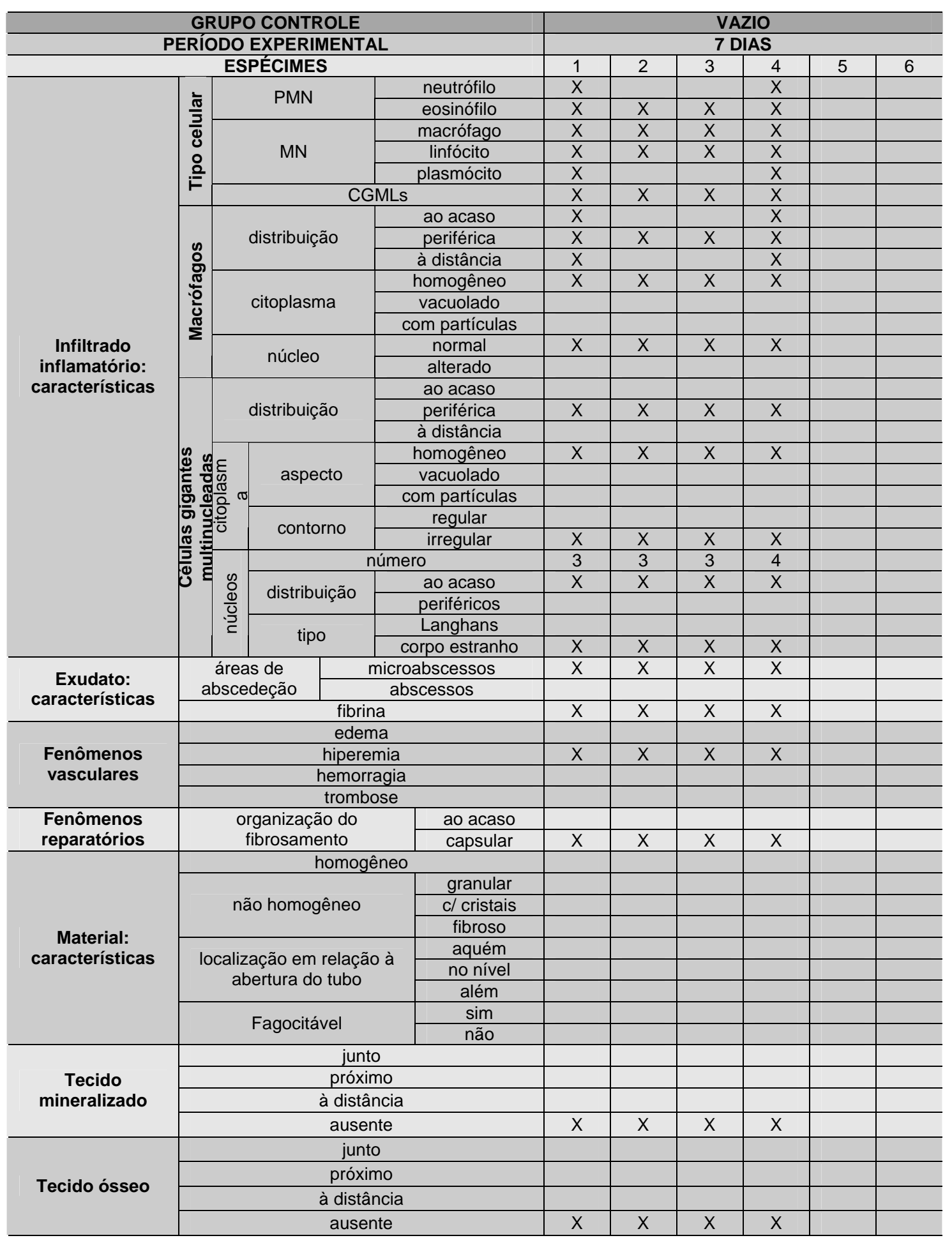




\section{GRUPO I - CONTROLE - TUBO VAZIO - 7 DIAS}

Figura 23 A - Aspecto microscópico panorâmico da transição entre os terços médio e apical do alvéolo dentário, evidenciando a resposta tecidual ao implante do tubo de polietileno vazio.

Figura 23 B - No interior do tubo e, imediatamente após sua abertura, o tecido conjuntivo apresenta-se densamente organizado com discreto infiltrado inflamatório e presença de fibroblastos jovens.

Figura 23 C - No tecido invaginado destaca-se a presença de vaso neoformado hiperêmico e congesto com leucócitos no seu interior.

Figura 23 D - Próximo ao fundo alveolar observa-se, a presença do tecido conjuntivo fibroso densamente organizado substituindo as áreas que antes eram ocupadas pelo coágulo.

Figura 23 E - Detalhe dos tecidos odontogênicos interpostos entre o fundo do alvéolo e o tubo de polietileno.

Figura 23 F - Aspecto do tecido de granulação localizado nas áreas de interface com o tubo. Notar a celularidade aumentada. 


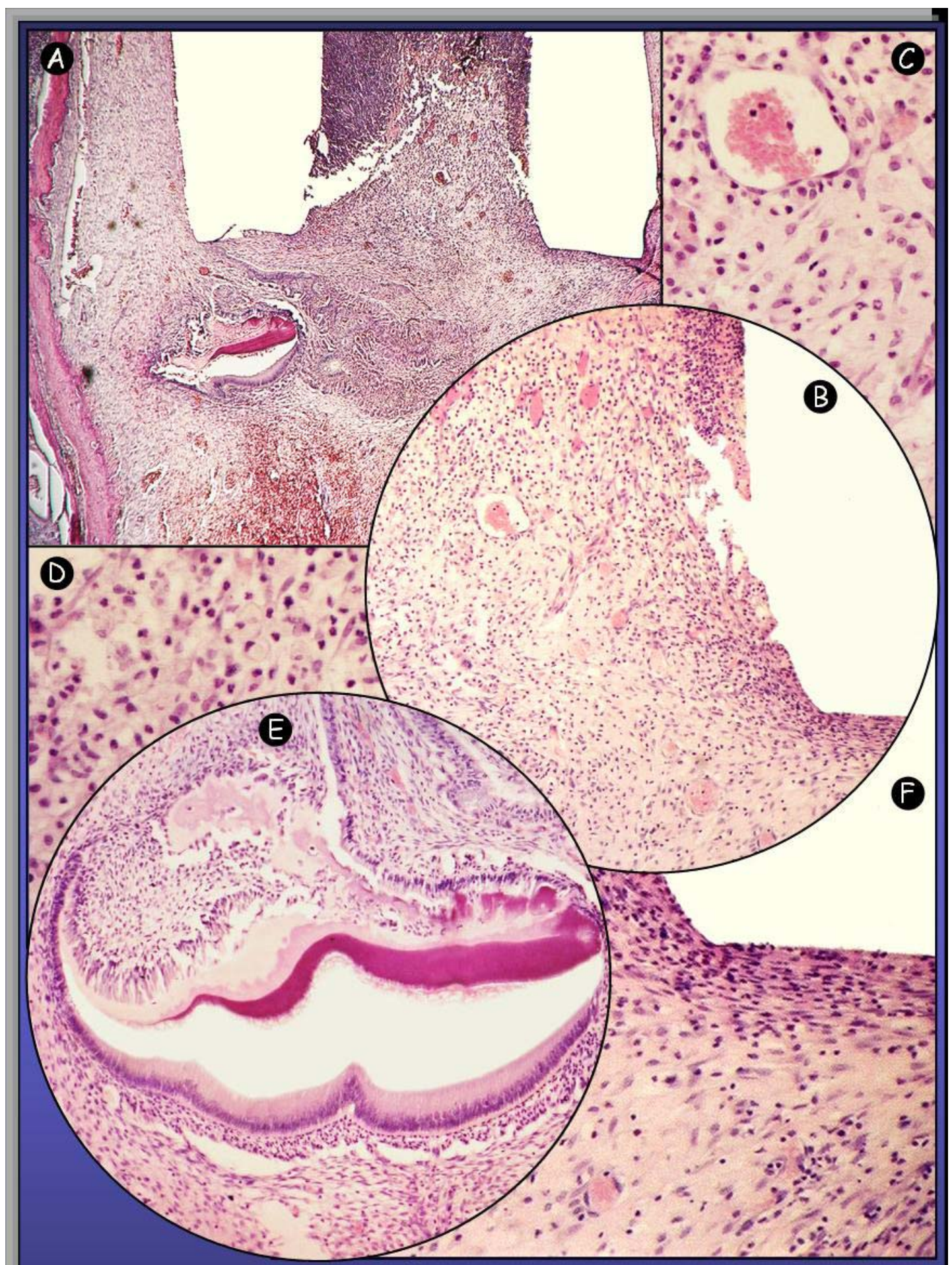

Figura 23 - Grupo Controle - 7 dias - Aspecto microscópico do implante de tubo de polietileno vazio em alvéolo dentário de rato observado em cortes longitudinais corados com H. E., após 7 dias. Destacam-se a presença de discreto infiltrado inflamatório no tecido conjuntivo subjacente, tecido conjuntivo invaginado para o interior do tubo e restos de tecido odontogênico interpostos entre a resposta inflamatória ao tubo e o fundo do alvéolo. 


\section{GRUPO II - EXPERIMENTAL - TUBO COM PROROOT MTA - 7 DIAS}

Imediatamente junto ao material foi observado uma faixa superficial de espessura irregular com necrose por coagulação, revelando fragmentação nuclear (Fig. 24 A,B,E); subjacente, visualizou-se um discreto infiltrado inflamatório composto predominantemente por macrófagos e eventuais linfócitos de permeio ao tecido conjuntivo composto por fibroblastos jovens e vasos neoformados (Fig. 24 A,B,D).

Em alguns casos observou-se, adjacente ao material, delgada faixa de tecido conjuntivo pouco organizado com discreto número de fibroblastos, alguns macrófagos e linfócitos.

Nas áreas de interface entre o tecido conjuntivo e o tubo notou-se, assim como no grupo controle, maior celularidade em relação à região apical do alvéolo que se constituiu, predominantemente, por macrófagos e células gigantes multinucleadas inflamatórias (Fig. 24 C).

Logo abaixo, em direção ao fundo do alvéolo, notou-se assim como no grupo controle, a presença do coágulo ainda desorganizado (Fig. $24 \mathrm{~A}$ ).

Em um dos espécimes observou-se pequenas trabéculas ósseas neoformadas com numerosos osteoblastos em suas bordas, em todos os outros, o espaço entre o material e o fundo do alvéolo estava ocupado por tecido conjuntivo pouco organizado e coágulo sangüíneo, ainda desorganizado. 
Quanto aos tipos celulares, observou-se, em todos os espécimes, a presença de macrófagos, linfócitos e células gigantes multinucleadas inflamatórias. Os eosinófilos estavam presentes em 4 espécimes, os plasmócitos em 2, porém não foi detectada a presença de neutrófilos em nenhum dos 6 espécimes avaliados.

No que se refere à localização dos macrófagos, observou-se distribuição periférica, citoplasmas homogêneos com partículas e núcleos normais em todos os espécimes.

Em relação às células gigantes multinucleadas inflamatórias, observou-se em todos os espécimes, distribuição periférica, citoplasma homogêneo de contorno irregular contendo partículas e núcleos distribuídos ao acaso.

Não se observou, quanto ao exudato, áreas de abscedeção nem a presença de fibrina próximo ao material em nenhum dos espécimes. Contudo, em relação aos fenômenos vasculares, observou-se hiperemia em todos os espécimes. Em relação aos fenômenos reparatórios, assim como no grupo controle, notou-se organização do fibrosamento de características capsulares.

Quanto às características do material, observou-se que o mesmo não apresentava homogeneidade, sendo granular e fagocitável. Sua localização, em todos os espécimes, foi no nível da abertura do tubo.

Quanto à presença e localização da deposição de tecidos mineralizado e ósseo, observou-se, em metade dos espécimes, uma mineralização próxima ao material e, em apenas um espécime, a presença de tecido ósseo, também localizado, próximo ao material.

Todos esses eventos microscópicos observados estão dispostos na tabela 7 . 
Tabela 7 - Grupo ProRoot MTA - 7 dias - Descrição atribuída aos eventos microscópicos observados nos espécimes analisados

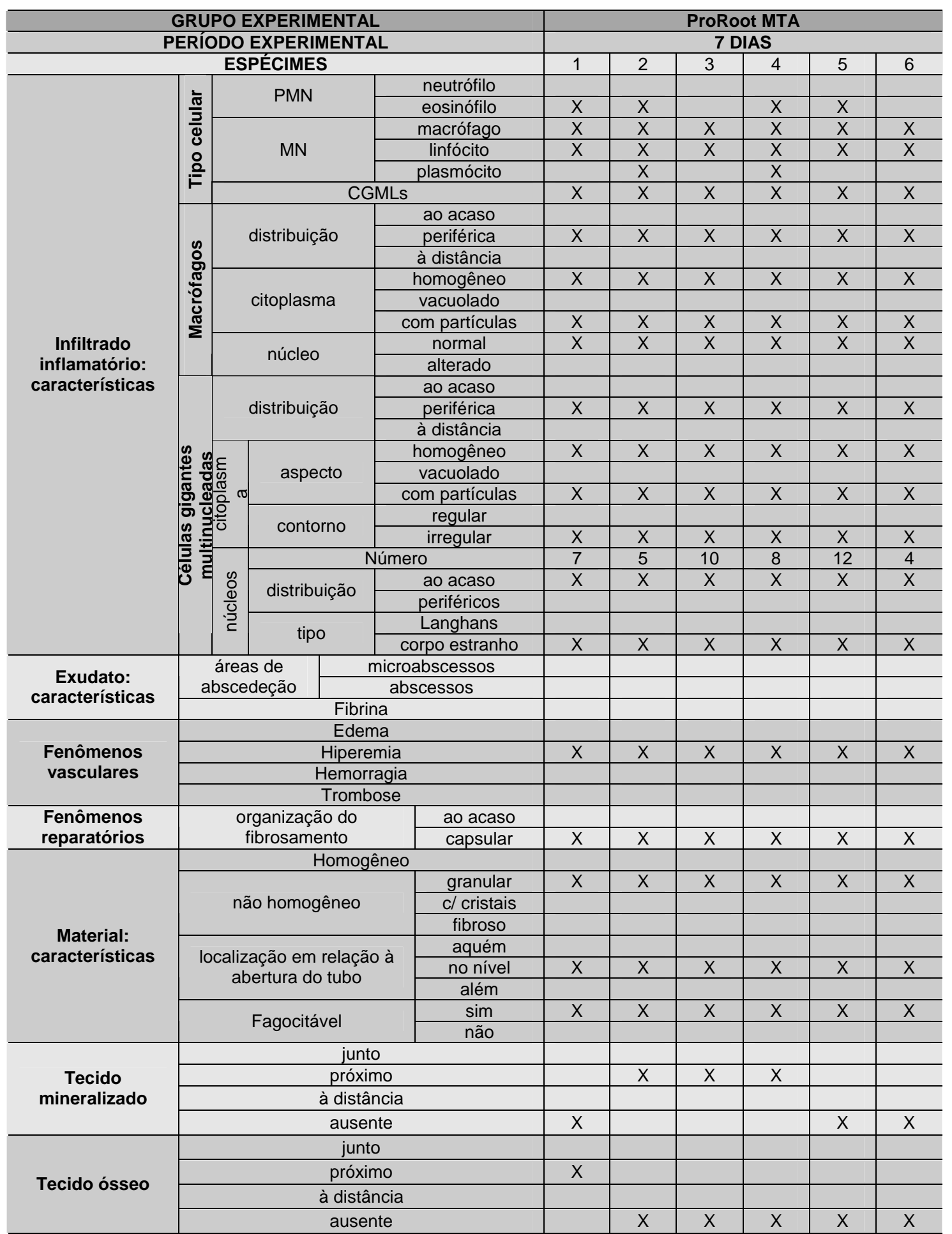




\section{GRUPO II - EXPERIMENTAL - TUBO COM PROROOT MTA - 7 DIAS}

Figura 24 A - Aspecto microscópico panorâmico da transição entre os terços médio e apical do alvéolo dentário, evidenciando a resposta tecidual ao implante do tubo de polietileno preenchido com o MTA.

Figura 24 B - Na região mais próxima ao fundo do alvéolo observa-se tecido conjuntivo ricamente celularizado (fibroblastos jovens), organizando-se junto ao coágulo. $\mathrm{Na}$ interface com o material, tal tecido apresenta-se, já, organizado.

Figura 24 C - Detalhe do tecido de granulação localizado próximo ao tubo. Notar celularidade aumentada.

Figura 24 D - Aspecto do tecido conjuntivo localizado logo abaixo do material.

Figura 24 E - Em maior aumento, observa-se, a interação do tecido conjuntivo com o material. Notar faixa superficial de espessura irregular com necrose por coagulação e aspecto do tecido conjuntivo subjacente. 


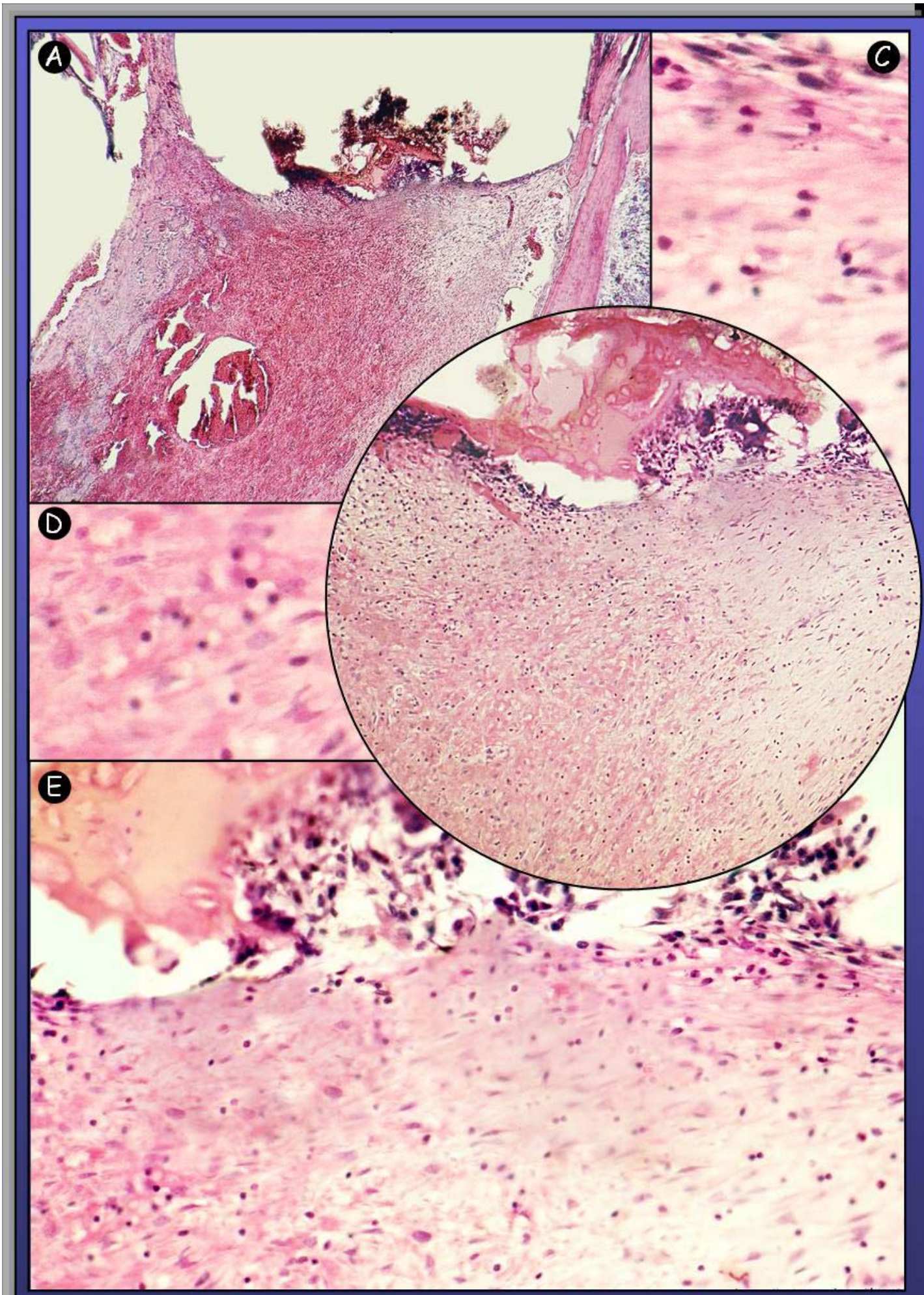

Figura 24 - ProRoot MTA - 7 dias - Aspecto microscópico do implante de tubo de polietileno com ProRoot MTA em alvéolo dentário de rato observado em cortes longitudinais corados com H. E., após 7 dias. Destacam-se a presença de faixa irregular com necrose por coagulação junto ao material e de discreto infiltrado inflamatório no tecido conjuntivo subjacente. 


\section{GRUPO III - EXPERIMENTAL - TUBO COM MBPC - 7 DIAS}

Constatou-se uma resposta inflamatória com algumas semelhanças daquelas observadas com o MTA. Na maioria dos espécimes observou-se, junto ao material, um discreto infiltrado inflamatório composto por macrófagos e linfócitos de permeio ao tecido conjuntivo que apresentava discreto número de fibroblastos jovens e vasos neoformados (Fig. 25 $A, B, C, D)$.

$\mathrm{Na}$ interface do material com o tecido conjuntivo notou-se uma faixa de hemorragia e fragmentação nuclear. No interior desta faixa observou-se restos celulares de permeio a um material hialino, provavelmente, fruto da interação entre o componente resinoso do material e o tecido. Logo abaixo, observou-se a presença de áreas basofílicas que, provavelmente servirão de matriz para a mineralização (Fig. 25 B,E,F).

Em alguns espécimes constatou-se o contato direto entre fibroblastos, eventuais macrófagos e células gigantes multinucleadas inflamatórias com a faixa hialina, por vezes, até com o próprio material (Fig. 25 D,E). Esta faixa apresentou-se mais ampla e espessa do que a faixa de necrose por coagulação superficial, verificada com o MTA.

Mais em direção ao fundo do alvéolo o tecido conjuntivo apresentou-se com aspecto vascular normal, discreto número de fibroblastos e eventuais linfócitos. Assim como nos dois outros grupos, havia a presença do coágulo ainda desorganizado, nesta região.

Mais próximo ao fundo do alvéolo observou-se, na maioria dos espécimes, delgadas trabéculas ósseas neoformadas com moderado número de osteoblastos. 
Em todos os espécimes, foram observados macrófagos, linfócitos e células gigantes multinucleadas inflamatórias, enquanto que, eosinófilos, neutrófilos e plasmócitos não estavam presentes.

Quanto aos macrófagos, notou-se, distribuição periférica, citoplasmas homogêneos e núcleos normais em todos os espécimes, sendo que, em 2 deles, os citoplasmas apresentavam-se com partículas.

Em relação às células gigantes multinucleadas inflamatórias, observou-se também, em todos os espécimes, distribuição periférica, citoplasma homogêneo de contorno irregular e núcleos distribuídos ao acaso. A presença de partículas foi observada em 4 dos 6 espécimes.

Não se observou, quanto ao exudato, áreas de abscedeção nem a presença de fibrina, próximo ao material, em nenhum espécime, enquanto que, quanto aos fenômenos vasculares, observou-se hemorragia em 4 dos 6 espécimes.

Quanto aos fenômenos reparatórios, assim como, no grupo controle e com o MTA, notou-se organização do fibrosamento de características capsulares.

Em relação às características do material, observou-se que o mesmo não apresenta homogeneidade, é granular, fagocitável, e sua localização, em todos os espécimes, foi no nível da abertura do tubo.

Quanto à presença e localização da deposição de tecido mineralizado e ósseo, observou-se, em apenas um espécime, mineralização próxima ao material, enquanto que, a neoformação óssea à distância estava presente em todos os espécimes.

Todos esses eventos microscópicos observados estão dispostos na tabela 8 . 
Tabela 8 - Grupo MBPc - 7 dias - Descrição atribuída aos eventos microscópicos observados nos espécimes analisados

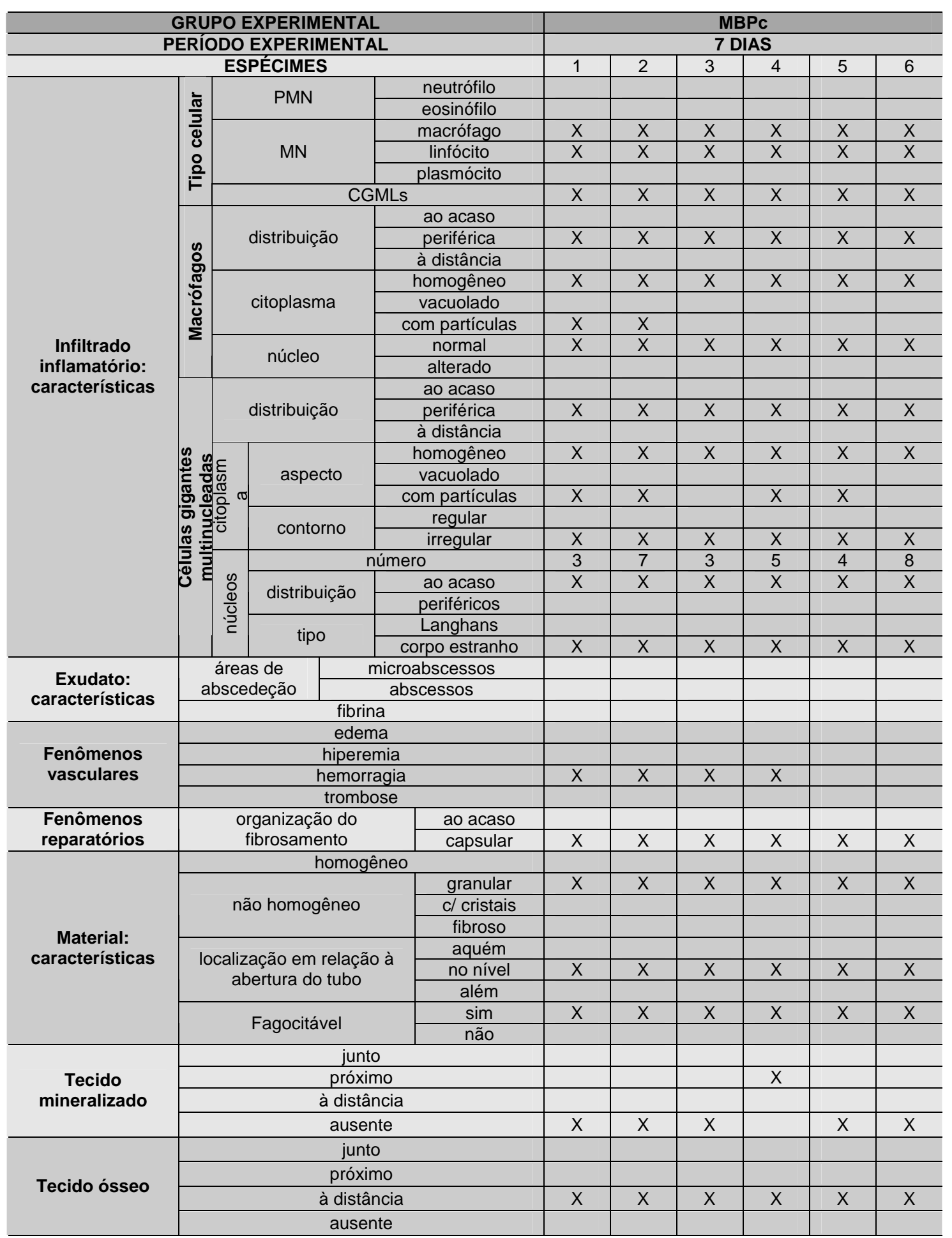




\section{GRUPO III - EXPERIMENTAL - TUBO COM MBPC - 7 DIAS}

Figura 25 A - Aspecto microscópico panorâmico da transição entre os terços médio e apical do alvéolo dentário, evidenciando a resposta tecidual ao implante de tubo de polietileno preenchido com o MBPc.

Figura 25 B - Detalhe da reação do tecido conjuntivo ao MBPc. Notar a presença do material, da faixa hialina e das áreas basofílicas.

Figura 25 C - Nota-se, em maior aumento, o material retrobturador e, subjacente, uma faixa de hemorragia e fragmentação nuclear. Abaixo desta faixa evidencia-se a presença de áreas basofílicas.

Figura 25 D - Observa-se, em maior aumento, o discreto infiltrado inflamatório subjacente ao material.

Figura 25 E - Aspecto da zona de fragmentação nuclear e da área basofílica subjacente.

Figura 25 F - Em maior aumento, nota-se, os restos celulares no interior da faixa hialina. 


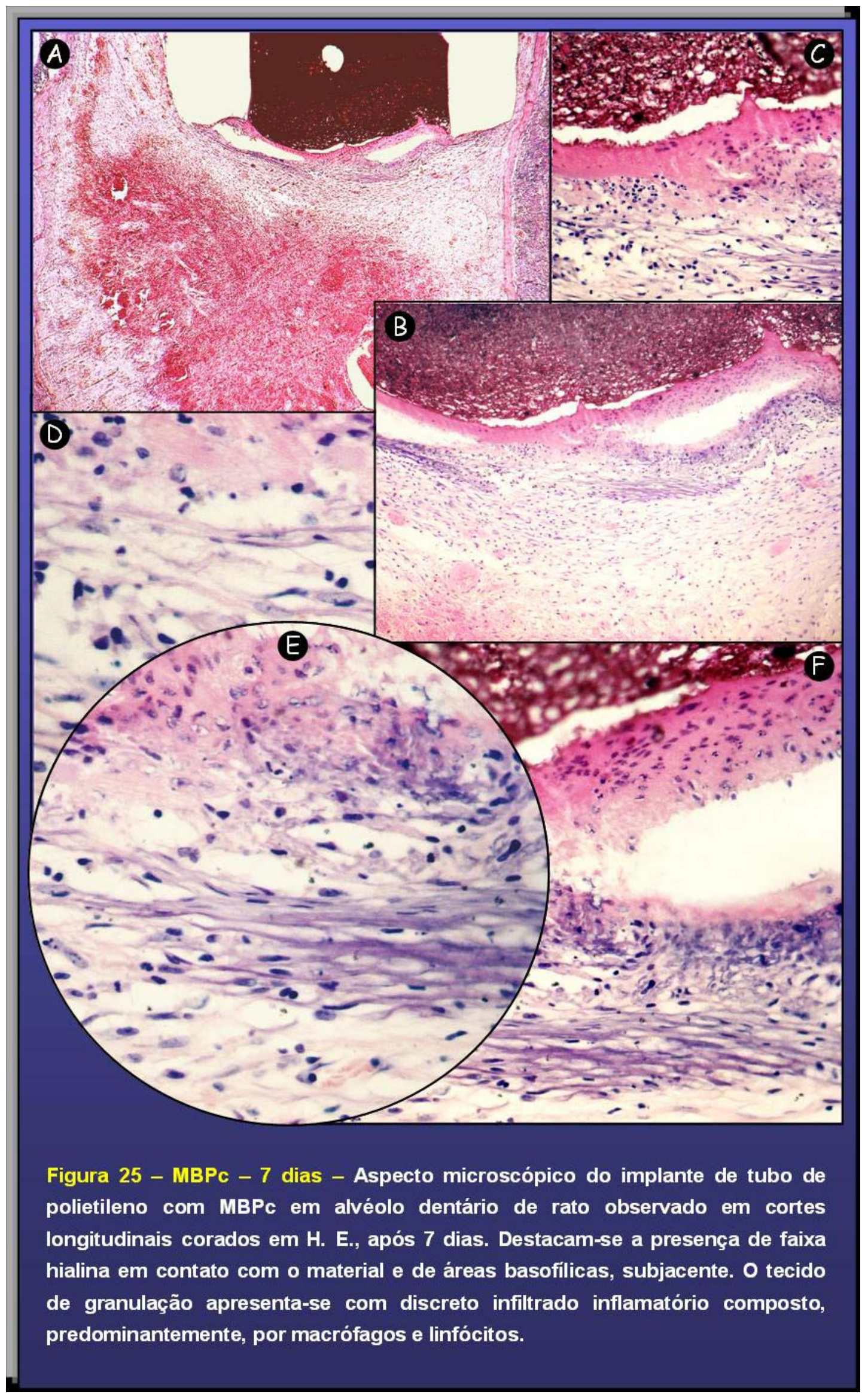




\section{GRUPO I - CONTROLE - TUBO VAZIO - 15 DIAS}

Junto à abertura do tubo de polietileno e em seu interior, observou-se, assim como, aos 7 dias, tecido invaginado com discreto infiltrado inflamatório, presença de fibroblastos jovens, alguns macrófagos e linfócitos (Fig. 26 A,B,C,E), porém, quando comparado ao período mais curto, este tecido, apresentou-se, com maior grau de organização. O tecido invaginado apresentou-se menos organizado à medida que se adentrou, mais profundamente, no espaço vazio, apresentando, como aos 7 dias, infiltrado inflamatório agudo, com células em necrose, revelando picnose e cariorrexe.

Em dois espécimes, junto ao tubo, observou-se uma estreita faixa ocupada por infiltrado inflamatório, que, caracterizou-se pela presença de numerosos polimorfonucleados tipo neutrófilos, ao lado de alguns linfócitos e macrófagos. Logo a seguir, evidenciou-se espessa camada ocupada por tecido conjuntivo com moderado número de fibroblastos ao lado de alguns macrófagos e linfócitos.

Mais em direção ao fundo do alvéolo, notou-se a presença de delgadas trabéculas ósseas neoformadas (Fig. 26 F,G), ao lado de tecido conjuntivo com moderado número de fibroblastos (Fig. 26 D), o que revelou uma fase de neoformação óssea, não visualizada aos 7 dias.

Em metade dos espécimes, além da neoformação óssea junto ao fundo do alvéolo, evidenciou-se, na área intermediária do espaço entre o tubo e o fundo do alvéolo, intensa neoformação óssea. 
Quanto aos tipos celulares, foi observado, em todos os espécimes, a presença de macrófagos, linfócitos e células gigantes multinucleadas inflamatórias. Neutrófilos, eosinófilos e plasmócitos estavam presentes em apenas metade dos espécimes. No que se refere à localização dos macrófagos, observou-se, distribuição periférica e à distância, em todos os espécimes e, distribuição ao acaso, em metade dos espécimes. Os citoplasmas apresentaram-se homogêneos e os núcleos normais. Em relação às células gigantes multinucleadas inflamatórias, observou-se em todos os espécimes, distribuição periférica, citoplasma homogêneo com contorno irregular e núcleos distribuídos ao acaso, semelhante ao observado aos 7 dias.

Quanto às características do exudato pode-se observar microabscessos em dois espécimes, no entanto, não se observou presença de fibrina próximo ao material em nenhum espécime.

Quanto aos fenômenos vasculares observou-se apenas a presença de hiperemia em todos os espécimes.

Quanto aos fenômenos reparatórios, considerando-se a organização do fibrosamento, foram encontradas apenas características capsulares.

Em relação à neoformação óssea, sua presença foi observada, próxima ao fundo do alvéolo em metade dos espécimes.

Todos esses eventos microscópicos observados estão dispostos na tabela 9. 
Tabela 9 - Grupo Controle - 15 dias - Descrição atribuída aos eventos microscópicos observados nos espécimes analisados

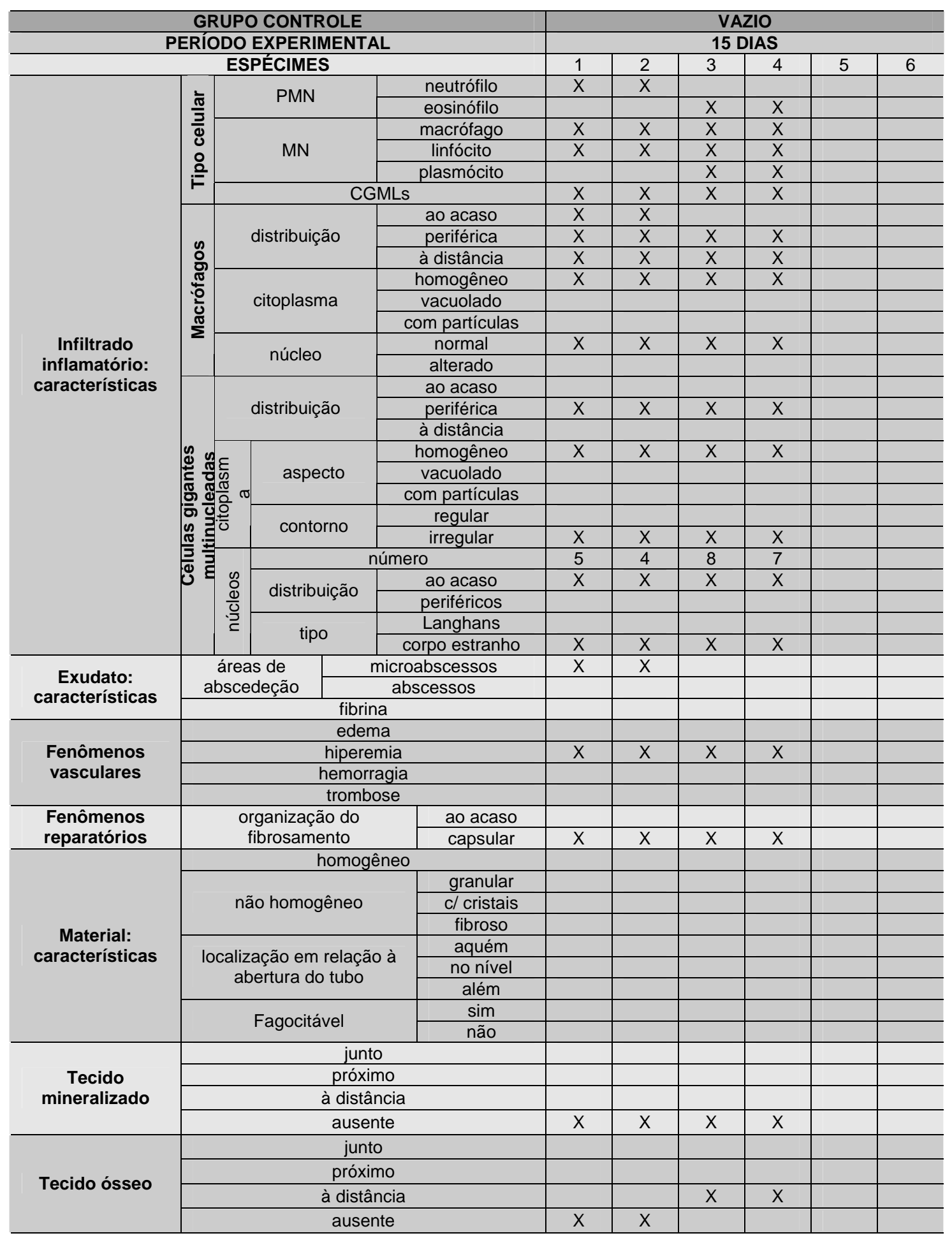




\section{GRUPO I - CONTROLE - TUBO VAZIO - 15 DIAS}

Figura 26 A - Aspecto microscópico panorâmico da transição entre os terços médio e apical do alvéolo dentário, evidenciando a resposta tecidual ao implante de tubo de polietileno vazio.

Figura 26 B - No interior do tubo e, imediatamente após sua abertura, o tecido conjuntivo apresenta-se um pouco mais organizado que aos 7 dias, evidenciando menor infiltrado inflamatório e menor quantidade de fibroblastos jovens.

Figura 26 C - Observa-se, em maior aumento, presença de fibroblastos jovens, alguns macrófagos e linfócitos junto ao tecido invaginado.

Figura 26 D - Próximo ao fundo alveolar observa-se a presença do tecido conjuntivo organizando-se junto à subjacente formação trabecular.

Figura 26 E - Em maior aumento, nota-se as características do tecido conjuntivo situado próximo à abertura do tubo de polietileno.

Figura 26 F - Aspecto microscópico panorâmico da transição entre o terço médio e apical do alvéolo dentário, evidenciando a neoformação óssea no fundo do alvéolo.

Figura 26 G - Próximo ao fundo do alvéolo nota-se intensa neoformação óssea. Notar a presença de delgadas trabéculas ósseas. 


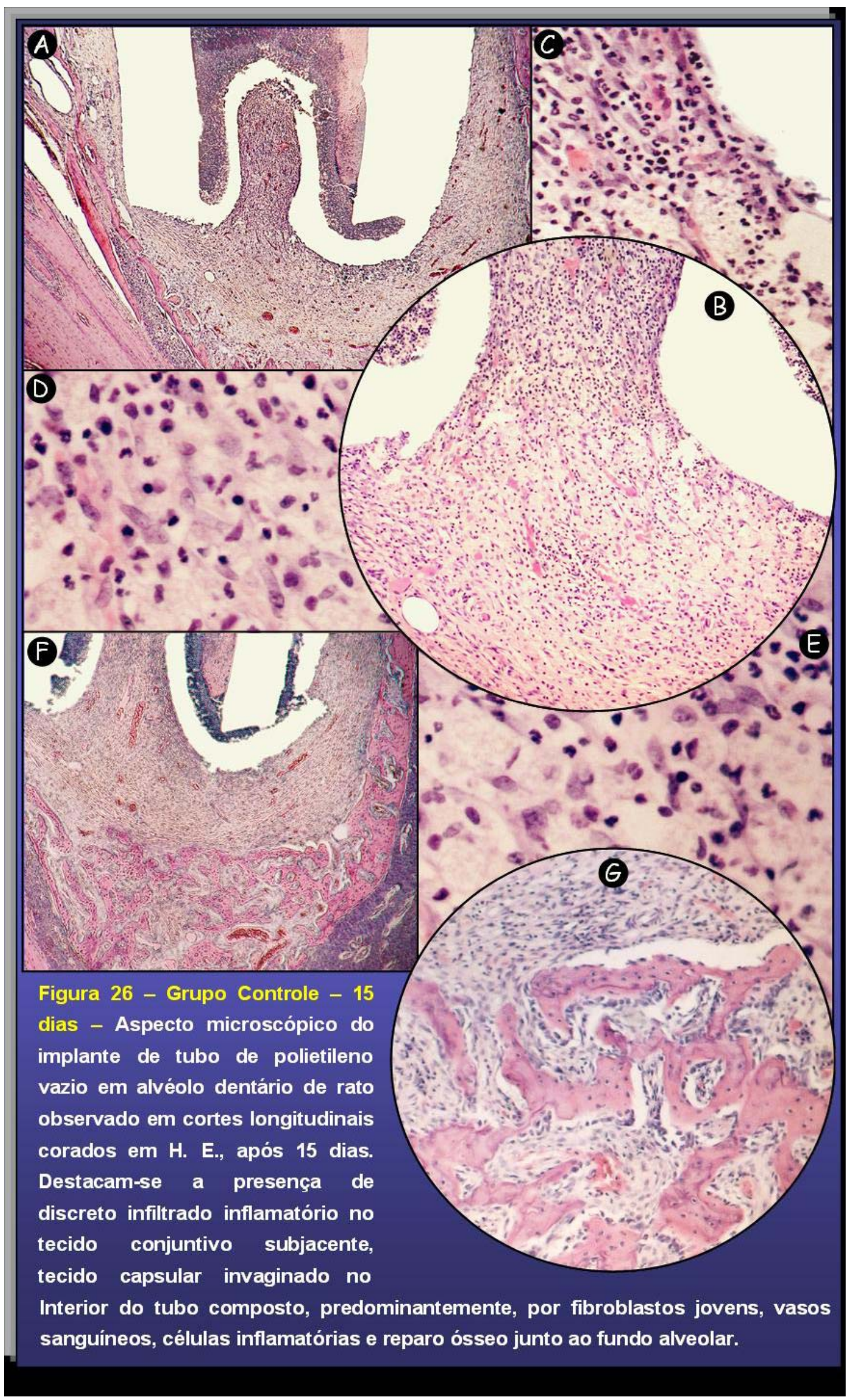




\section{GRUPO II - EXPERIMENTAL - TUBO COM PROROOT MTA - 15 DIAS}

Adjacente ao material notou-se aspectos microscópicos semelhantes aos observados aos 7 dias, porém mais organizados, apresentando uma faixa superficial de espessura irregular, com necrose por coagulação; subjacente, visualizou-se discreto infiltrado inflamatório composto, predominantemente, por macrófagos e linfócitos de permeio ao tecido conjuntivo que, por sua vez, apresentava fibroblastos jovens e vasos neoformados (Fig. 27 A,B,C).

Observou-se, ainda, abaixo das áreas de necrose por coagulação, na interface entre o tecido conjuntivo e o material, a presença de áreas basofílicas irregulares que, provavelmente, serviriam ao longo do tempo, de matrizes para a mineralização (Fig. 27 B,E). Esta basofilia, provavelmente, decorreu da presença de restos necróticos de células do tecido de granulação, que apresentam afinidade tintorial pela hematoxilina.

A seguir, notou-se espessa camada ocupada por tecido conjuntivo bem vascularizado com moderado número de fibroblastos (Fig. 27 $B, E)$, ao lado de alguns macrófagos e linfócitos. Nessa região, o tecido de preenchimento, apresentou características de tecido conjuntivo dado o seu grau de organização, celularidade e quantidade de matriz extracelular.

Mais em direção ao fundo do alvéolo, o tecido conjuntivo apresentou as mesmas características, no entanto, pequenas trabéculas ósseas neoformadas (Fig. 27 A,D) com discreto número de osteoblastos, foram visualizadas, nessa região.

Em metade dos espécimes, observou-se trabéculas ósseas neoformadas e numerosos osteoblastos. Nos outros espécimes, o processo de ossificação não foi evidenciado e o espaço entre o material e o fundo do alvéolo encontrava-se preenchido por tecido de granulação bem organizado. 
Em todos os espécimes, observou-se, a presença de macrófagos, linfócitos e células gigantes multinucleadas inflamatórias. Neutrófilos e plasmócitos não estavam presentes, já eosinófilos, foram encontrados, em apenas um espécime.

No que se refere à localização dos macrófagos, observou-se distribuição periférica, citoplasmas homogêneos e núcleos normais, em todos os espécimes. A presença de partículas foi verificada em quatro espécimes.

As células gigantes multinucleadas inflamatórias apresentaram as mesmas características quanto à distribuição e quanto ao citoplasma observados nos macrófagos, assim como, a presença de partículas em quatro espécimes. O citoplasma apresentou-se com contorno irregular e os núcleos, distribuídos ao acaso.

Não foram observadas áreas de abscedeção nem presença de fibrina próximo ao material. Quanto aos fenômenos vasculares, observouse hiperemia em todos os espécimes.

Em relação aos fenômenos reparatórios, encontrou-se, na organização do fibrosamento, apenas características capsulares. Quanto às características do material, observou-se que o mesmo não apresentou homogeneidade, sendo granular e fagocitável. Sua localização, em todos os espécimes, foi no nível da abertura do tubo.

Quanto à presença e localização da deposição de tecido mineralizado e ósseo, observou-se, em metade dos espécimes, mineralização junto ao material. Foi evidenciada a neoformação óssea próxima ao material em um espécime e, à distância, em dois.

Todos esses eventos microscópicos observados estão dispostos na tabela 10. 
Tabela 10 - Grupo ProRoot MTA - 15 dias - Descrição atribuída aos eventos microscópicos observados nos espécimes analisados

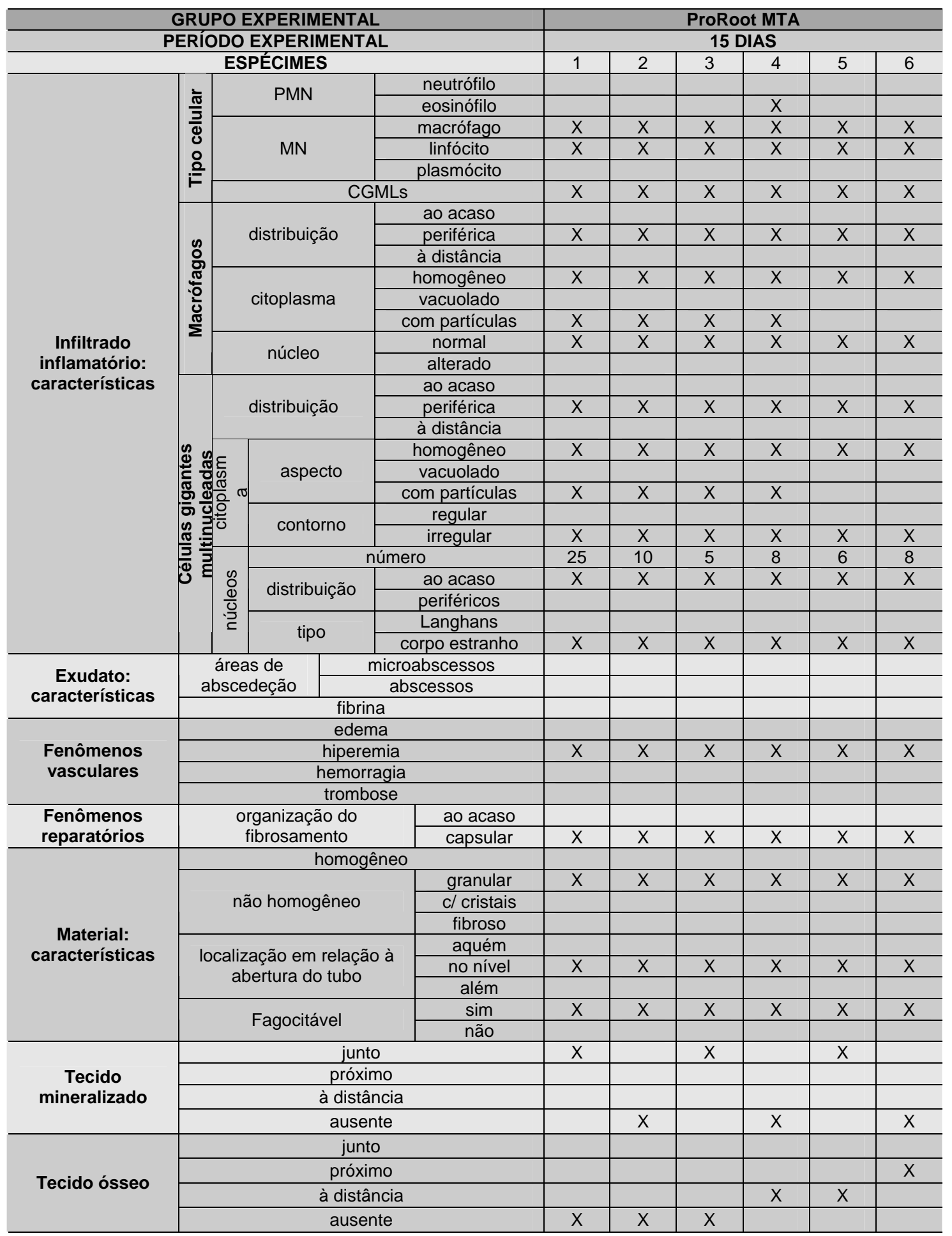




\section{GRUPO II - EXPERIMENTAL - TUBO COM PROROOT MTA - 15 DIAS}

Figura 27 A - Aspecto microscópico panorâmico da transição entre o terço médio e apical do alvéolo dentário, evidenciando a resposta tecidual ao implante de tubo de polietileno preenchido com o MTA.

Figura 27 B - Na interface com o MTA, observa-se, material eosinofílico amorfo e, subjacente, área basofílica irregular. Justaposto às áreas basofílicas, nota-se tecido de granulação maduro.

Figura 27 C - Em maior aumento, nota-se o tecido conjuntivo densamente organizado, que apresenta grande quantidade de matriz colagênica de permeio a células fibroblásticas e alguns vasos sangüíneos.

Figura 27 D - Interposto entre a formação do tecido ósseo, junto às paredes alveolares e o tubo implantado, nota-se delgada faixa de tecido conjuntivo de característica capsular.

Figura 27 E - Ainda, em maior aumento, observa-se, a constituição da área basofílica irregular, justaposta ao material eosinofílico amorfo. 


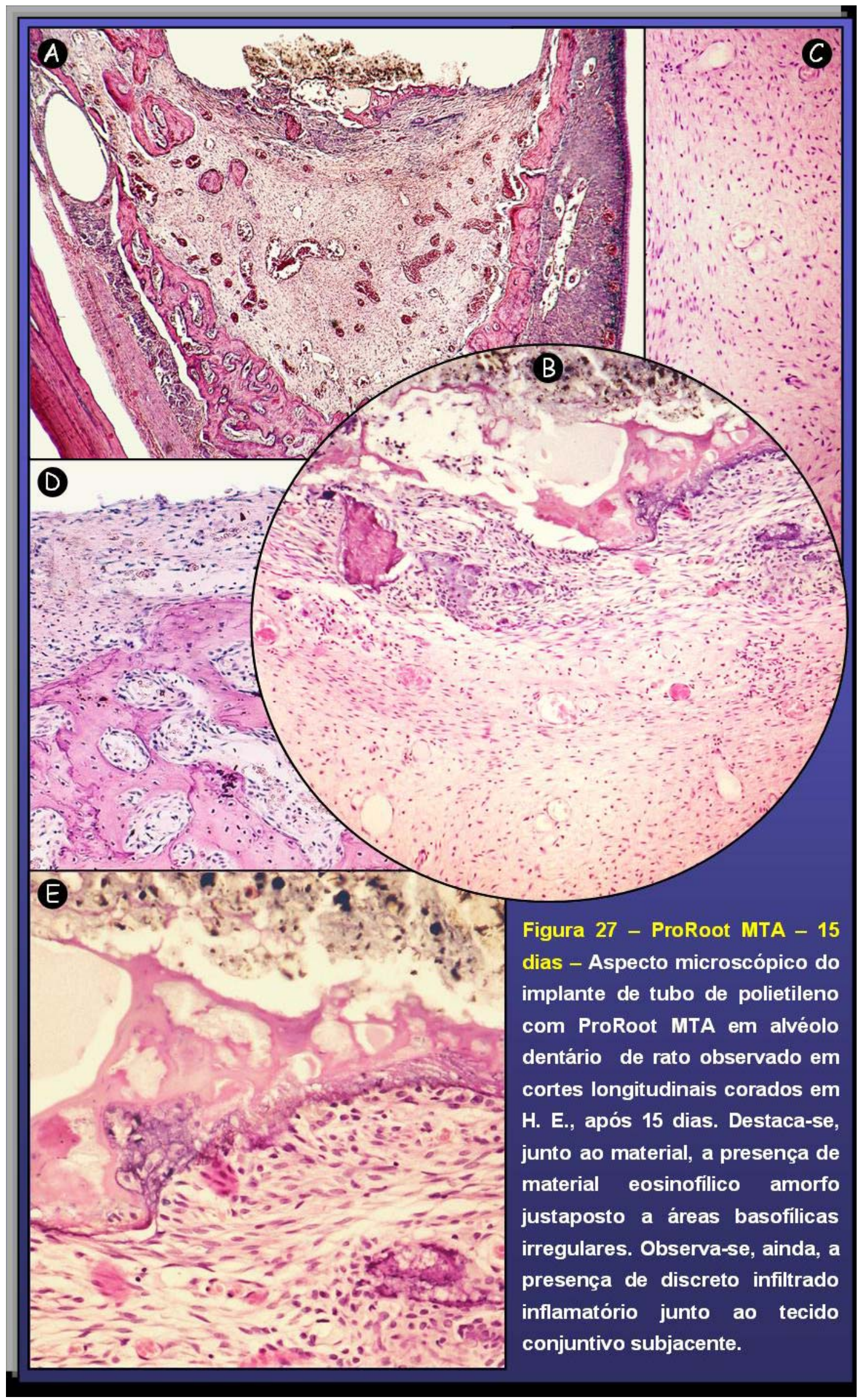




\section{GRUPO III - EXPERIMENTAL - TUBO COM MBPC - 15 DIAS}

Evidenciou-se, mais uma vez, uma resposta inflamatória com algumas semelhanças daquelas observadas com o MTA. Na interface do material com o tecido conjuntivo notou-se, assim como aos 7 dias, uma faixa de hemorragia e fragmentação nuclear. Observou-se, também, o contato direto entre fibroblastos, eventuais macrófagos e células gigantes multinucleadas inflamatórias com a faixa hialina e, por vezes, até com o próprio material (Fig. 28 D,E). A faixa hialina apresentou em seu interior células fragmentadas, que foram caracterizadas pela presença de conteúdo nucléico disperso (Fig. 28 C), provavelmente fruto da interação do componente resinoso do material com o tecido de granulação. Esta faixa apresentou-se mais ampla e espessa do que a faixa de necrose por coagulação superficial verificada com o MTA.

Observou-se, ainda, que o tecido próximo ao material, também apresentou áreas basofílicas semelhantes às verificadas com 0 MTA, porém mais irregulares (Fig. 28 B,C,F), compostas por macrófagos, eventuais linfócitos e células gigantes multinucleadas inflamatórias.

Em alguns espécimes, notou-se, junto ao material, áreas de infiltrado inflamatório com predominância de macrófagos e eventuais linfócitos de permeio ao tecido de granulação, composto por discreto número de fibroblastos e vasos sangüíneos. Observou-se, também, tecido de granulação reorganizando as áreas onde o coágulo persistiu (Fig. 28 A). Em outros espécimes, observou-se, junto ao material e nas áreas mais afastadas, tecido de granulação com maior número de fibroblastos, alguns macrófagos e linfócitos, e presença de coágulo, porém mais organizado que aos 7 dias (Fig. 28 D). Em regiões situadas mais próximas ao fundo do alvéolo, notou-se, na maioria dos espécimes, pequenas trabéculas ósseas neoformadas. 
Foi observado, quanto aos tipos celulares, em todos os espécimes, a presença de macrófagos, linfócitos e células gigantes multinucleadas inflamatórias, enquanto que, neutrófilos e plasmócitos não estavam presentes. Eosinófilos foram encontrados em apenas um espécime.

Quanto aos macrófagos, notou-se, distribuição periférica em todos os espécimes e, à distância, em apenas um. Observou-se citoplasma homogêneo e núcleos normais em todos os espécimes, sendo que, em dois, o citoplasma apresentou-se com partículas.

Em relação às células gigantes multinucleadas inflamatórias, observou-se, também, em todos os espécimes, distribuição periférica, citoplasma homogêneo de contorno irregular e núcleos distribuídos ao acaso. A presença de partículas foi observada em um dos 6 espécimes.

Não se observou, quanto ao exudato, áreas de abscedeção nem a presença de fibrina próximo ao material, em nenhum dos espécimes. Em relação aos fenômenos vasculares, observou-se edema e hiperemia em apenas um espécime. Quanto aos fenômenos reparatórios, assim como, nos outros dois grupos, notou-se organização do fibrosamento de características capsulares.

Quanto às características do material, observou-se que o mesmo não apresentou homogeneidade, sendo granular, fagocitável, e sua localização, em 5 espécimes, foi no nível da abertura do tubo e, em um, além. Não se observou a presença de tecido mineralizado, enquanto que o tecido ósseo estava presente em 5 espécimes, localizado próximo ao material em três e, à distância, em dois.

Todos esses eventos microscópicos observados estão dispostos na tabela 11. 
Tabela 11 - Grupo MBPc - 15 dias - Descrição atribuída aos eventos microscópicos observados nos espécimes analisados

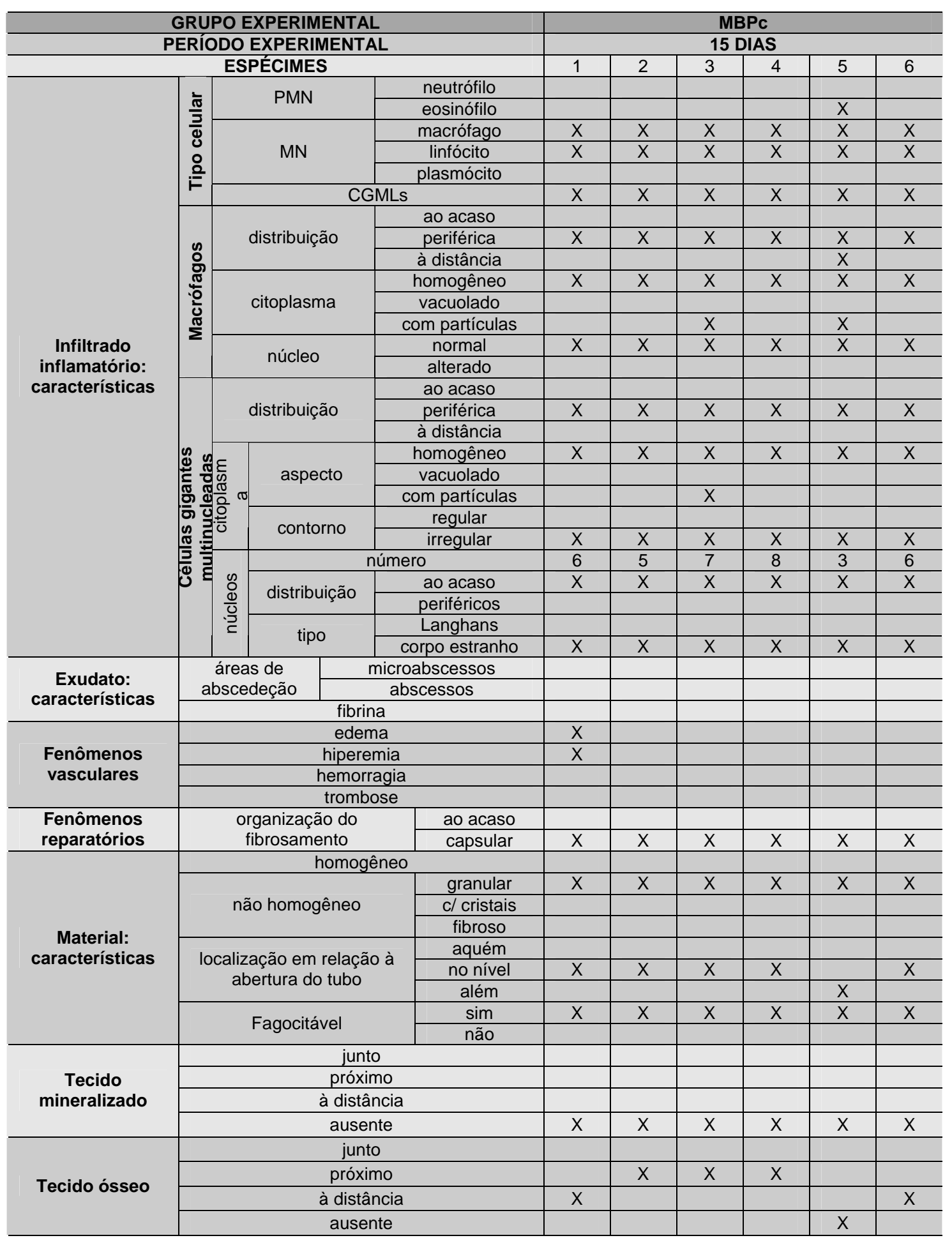




\section{GRUPO III - EXPERIMENTAL - TUBO COM MBPc - 15 DIAS}

Figura 28 A - Aspecto microscópico panorâmico da transição entre os terços médio e apical do alvéolo dentário, evidenciando a resposta tecidual ao implante de tubo de polietileno preenchido com o MBPC.

Figura 28 B - Nesse aumento, observa-se as características do infiltrado inflamatório subjacente ao material, que se apresenta constituído, predominantemente, por macrófagos e linfócitos de permeio ao tecido conjuntivo composto por fibroblastos jovens e vasos neoformados.

Figura 28 C - Nota-se, em maior aumento, junto ao material, faixa hialina eosinofílica amorfa; subjacente a ela, observa-se a presença de faixa irregular de tecido basofílico.

Figura 28 D - Neste espécime, nota-se, um estádio mais avançado da dissolução do coágulo pelo tecido de granulação, tecido este, que apresenta discreto infiltrado inflamatório mononucleado e baixa celularidade, rico em matriz colagênica.

Figura 28 E - Evidencia-se, nesta magnificação, o contato direto entre fibroblastos e o MBPc.

Figura 28 F - Em maior aumento, destaca-se, a presença de corpúsculos birrefringentes esferoidais próximos à área basofílica, provavelmente, advindo do plasma sangüíneo da área hemorrágica. 


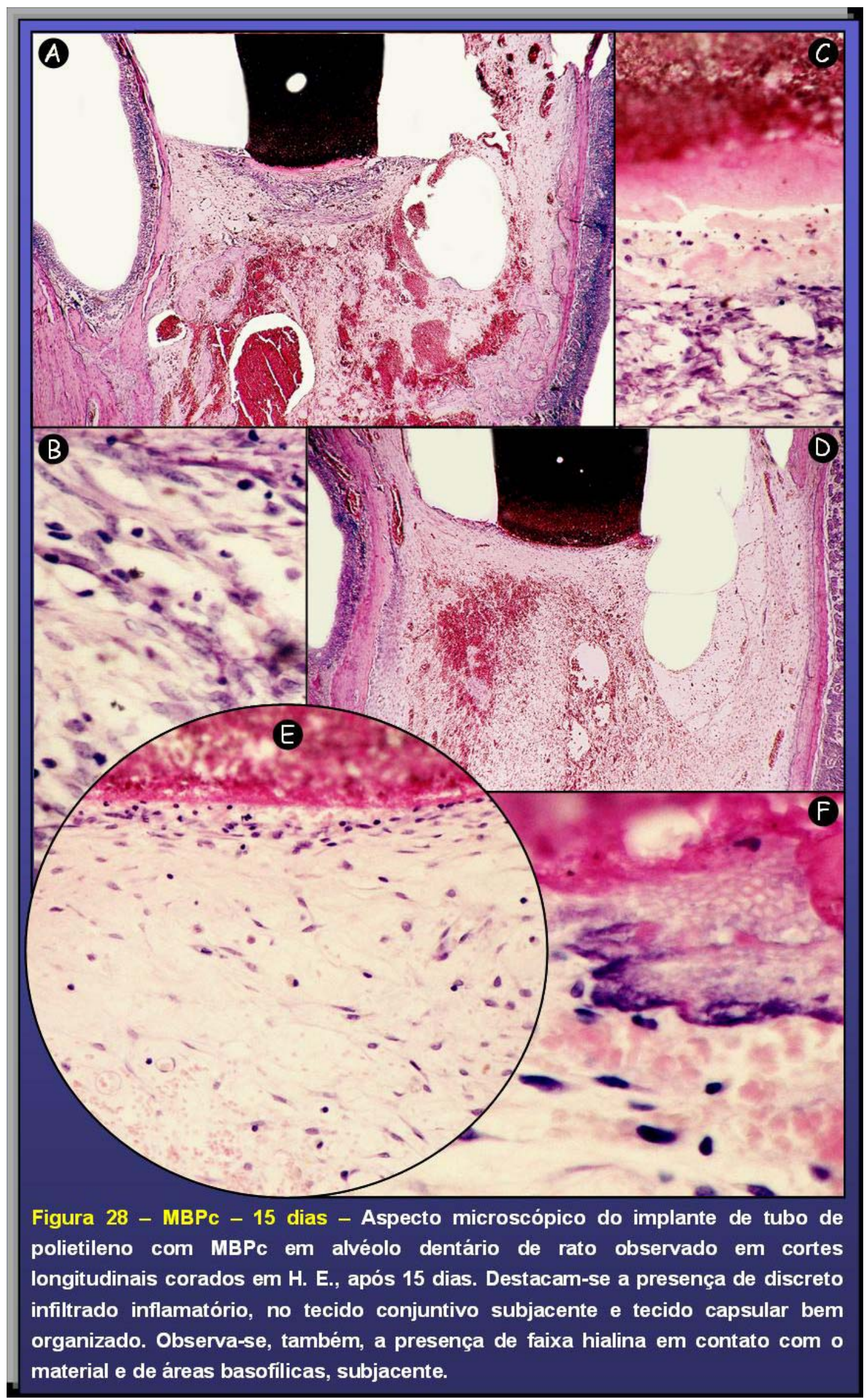




\section{GRUPO I - CONTROLE - TUBO VAZIO - 30 DIAS}

Junto à abertura do tubo de polietileno, observou-se tecido conjuntivo com discreto infiltrado inflamatório, presença de fibroblastos, alguns macrófagos e linfócitos (Fig. 29 A,B,F,G), porém, quando comparado aos períodos de 7 e 15 dias, esse tecido, apresentou-se com maior grau de organização. Subjacente, notou-se, em alguns casos, trabéculas ósseas neoformadas ocupando o espaço correspondente à abertura do tubo (Fig. 29 E,F,G). O tecido conjuntivo, nas proximidades, apresentou pouca vascularização e moderado número de fibroblastos, ao lado de alguns linfócitos e macrófagos.

Em um espécime, notou-se a presença de tecido ósseo, localizado próximo à abertura do tubo (Fig. 29 E,F); subjacente, observou-se tecido conjuntivo bem organizado, composto por rica matriz colagênica, pouco celularizada (Fig. 29 D).

Na área intermediária, entre o tubo e o fundo do alvéolo, notou-se, em todos os espécimes, tecido conjuntivo pouco vascularizado com maior número de fibroblastos. A neoformação de tecido ósseo, localizado próximo ou à distância da luz do tubo, caracterizou-se pela presença de delgadas trabéculas ósseas (Fig. 29 G).

Junto ao fundo alveolar, evidenciou-se a presença de tecido ósseo neoformado, porém, com maior grau de organização em relação aos períodos anteriores caracterizado pela presença de trabéculas ósseas mais espessas (Fig. 29 A,C). 
Quanto aos tipos celulares, foi observado, em todos os espécimes, a presença de macrófagos, linfócitos e células gigantes multinucleadas inflamatórias, enquanto que, plasmócitos estavam presentes em três e, eosinófilos, em apenas um espécime, dos quatro avaliados. Neutrófilos não foram encontrados. Quanto aos macrófagos, observou-se distribuição periférica em todos e à distância em metade deles. Notou-se citoplasmas homogêneos e núcleos normais em todos os espécimes. Em relação às células gigantes multinucleadas inflamatórias, observou-se, também, em todos os espécimes, distribuição periférica, citoplasma homogêneo de contorno irregular e núcleos distribuídos ao acaso.

Não se observou, quanto ao exudato, áreas de abscedeção nem a presença de fibrina próximo ao material em nenhum dos espécimes, enquanto que, quanto aos fenômenos vasculares, observou-se hiperemia em todos os espécimes.

Quanto aos fenômenos reparatórios, notou-se organização do fibrosamento de características capsulares em todos os espécimes.

Em relação à neoformação óssea, observou-se, em todos os espécimes, deposição de tecido ósseo localizado próximo à abertura do tubo em um espécime e, à distância, nos outros três.

Todos esses eventos microscópicos observados estão dispostos na tabela 12 . 


\section{Tabela 12 - Grupo Controle - 30 dias - Descrição atribuída aos eventos microscópicos observados nos espécimes analisados}

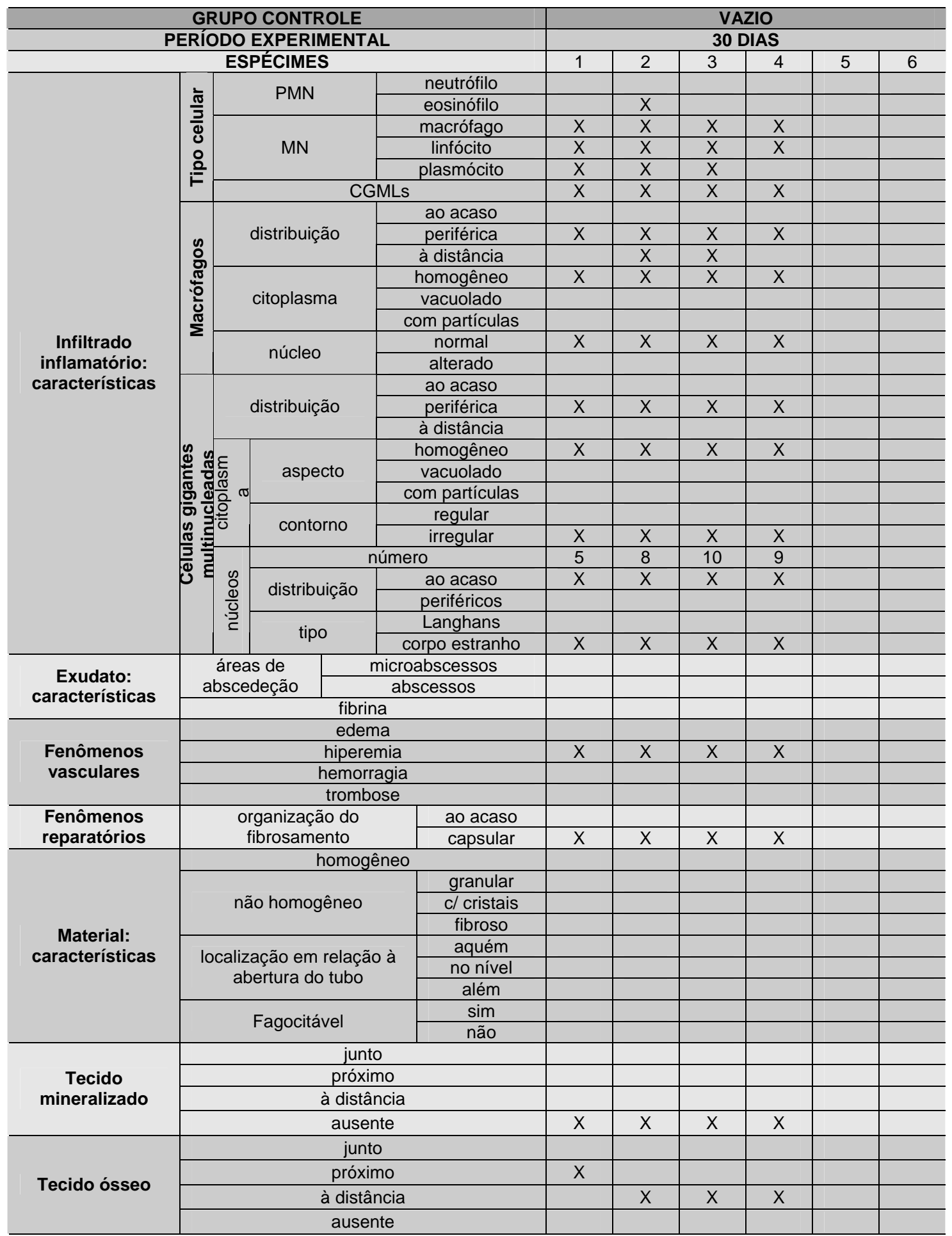




\section{GRUPO I - CONTROLE - TUBO VAZIO - 30 DIAS}

Figura 29 A - Aspecto microscópico panorâmico da transição entre o terço médio e apical do alvéolo dentário, evidenciando a resposta tecidual ao implante de tubos de polietileno vazios.

Figura 29 B - Entre a neoformação óssea localizada próxima à luz do tubo e, o tecido ósseo, situado junto ao fundo alveolar, evidencia-se tecido conjuntivo densamente organizado.

Figura 29 C - Na região intermediária, entre a neoformação óssea, localizada próxima à abertura do tubo e à cortical alveolar, evidenciase, a presença de vasos sangüíneos, de permeio ao tecido conjuntivo e finas trabéculas ósseas.

Figura 29 D - Características do tecido conjuntivo localizado entre a neoformação óssea e o fundo do alvéolo, onde se observa baixa celularidade e grande quantidade de matriz colagênica.

Figura 29 E - Aspecto do tecido conjuntivo localizado imediatamente após a abertura do tubo e subjacente neoformação óssea. Nota-se também, a presença de vasos sangüíneos de permeio a este tecido conjuntivo densamente organizado.

Figura 29 F - Aspecto da neoformação óssea localizada próxima à luz do tubo, evidenciando a presença de osteócitos no interior da matriz mineralizada e de osteoblastos depositando matriz óssea.

Figura 29 G - Nota-se, em maior aumento, a presença de tecido conjuntivo interposto entre a neoformação óssea e o tubo, caracterizado pela presença de fibroblastos, alguns macrófagos e linfócitos. 


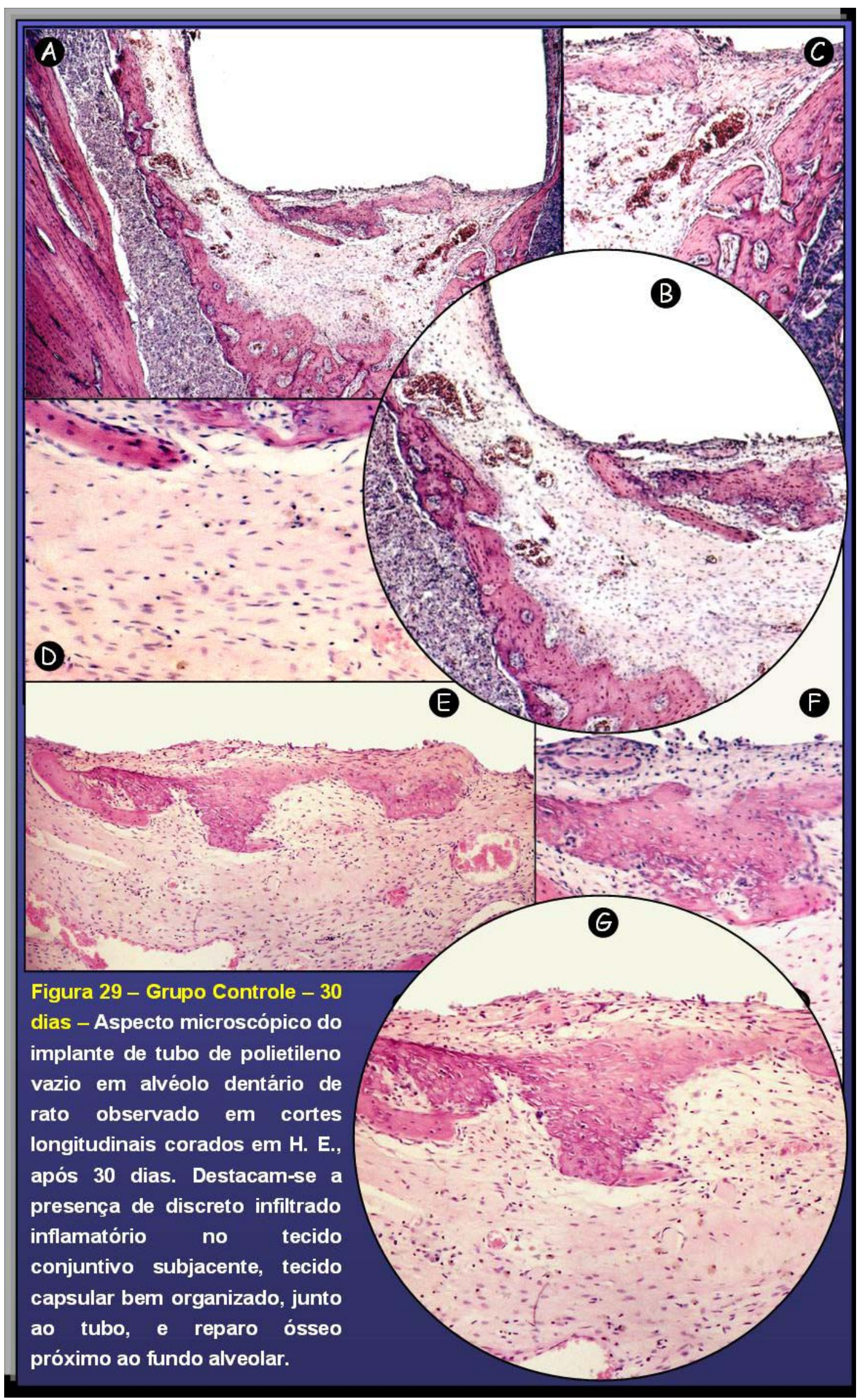




\section{GRUPO II - EXPERIMENTAL - TUBO COM PROROOT MTA - 30 DIAS}

O tecido conjuntivo, subjacente ao material, apresentou avançado estádio organizacional, quando comparado aos períodos de 7 e 15 dias. Este tecido foi caracterizado pela presença de discreto infiltrado inflamatório mononucleado e por fibroblastos em meio à matriz extracelular, rica em colágeno. Notou-se, ainda, a presença de delgadas trabéculas ósseas em regiões que, em períodos menores, apresentava ainda, tecido de granulação e coágulo (Fig. 30 A,B).

Observou-se, junto ao material, faixa de tecido mineralizado osteóide neoformado que apresentou, inclusive, osteócitos em seu interior (Fig. $30 \mathrm{C}$ ). Subjacente, notou-se tecido conjuntivo densamente organizado e colagenizado. Este tecido apresentou alta celularidade, caracterizada por células em diferentes estádios de diferenciação (Fig. 30 D,E). À medida que se aproximou do fundo do alvéolo, o grau de celularidade diminuiu e a quantidade de tecido ósseo neoformado aumentou. Destacou-se, neste período pós-operatório, a ausência das faixas de necrose encontradas aos 7 e 15 dias que, provavelmente, serviram de matriz para a deposição do tecido osteóide, encontrado aos 30 dias.

Junto ao tecido conjuntivo, observou-se a presença de delicadas trabéculas neorformadas em estádio de mineralização, que aumentou em quantidade, à medida que se aproximou do fundo do alvéolo (Fig. 30 A,B).

Em todos os espécimes, observou-se, na região intermediária entre o material e o fundo do alvéolo, a presença de tecido conjuntivo maduro e tecido ósseo.

Junto ao fundo alveolar, evidenciou-se a deposição de tecido ósseo, caracterizado por trabéculas mais espessas em meio ao tecido conjuntivo maduro (Fig. 30 A). 
Em todos os espécimes, observou-se a presença de macrófagos, linfócitos e células gigantes multinucleadas inflamatórias. Neutrófilos e plasmócitos não estavam presentes, já eosinófilos, foram encontrados em apenas um espécime.

No que se refere à localização dos macrófagos, observou-se distribuição periférica, em todos os espécimes. Os citoplasmas apresentaram-se homogêneos e núcleos normais e, em cinco espécimes, notou-se partículas junto ao citoplasma.

Em todos os espécimes, as células gigantes multinucleadas inflamatórias apresentaram distribuição periférica e citoplasmas homogêneos. Notou-se a presença de partículas em metade dos espécimes. Os citoplasmas apresentaram-se com contorno irregular e, os núcleos distribuídos ao acaso. Não foram observadas áreas de abscedeção nem presença de fibrina próximo ao material e, quanto aos fenômenos vasculares, observou-se hiperemia em dois espécimes.

Quanto aos fenômenos reparatórios, evidenciou-se, na organização do fibrosamento apenas características capsulares. Quanto às características do material, observou-se que o mesmo não apresentou homogeneidade, sendo granular e fagocitável e sua localização, em todos os espécimes, foi no nível da abertura do tubo.

Quanto à presença e localização da deposição de tecido mineralizado e ósseo observou-se, em cinco espécimes, a ocorrência de mineralização que se localizou, em um, junto ao material, em três, próximo, e em um, à distância dele. A neoformação óssea encontrada se localizou próxima ao material, em metade dos espécimes e, na outra metade, à distância.

Todos esses eventos microscópicos observados estão dispostos na tabela 13 . 
Tabela 13 - Grupo ProRoot MTA - 30 dias - Descrição atribuída aos eventos microscópicos observados nos espécimes analisados

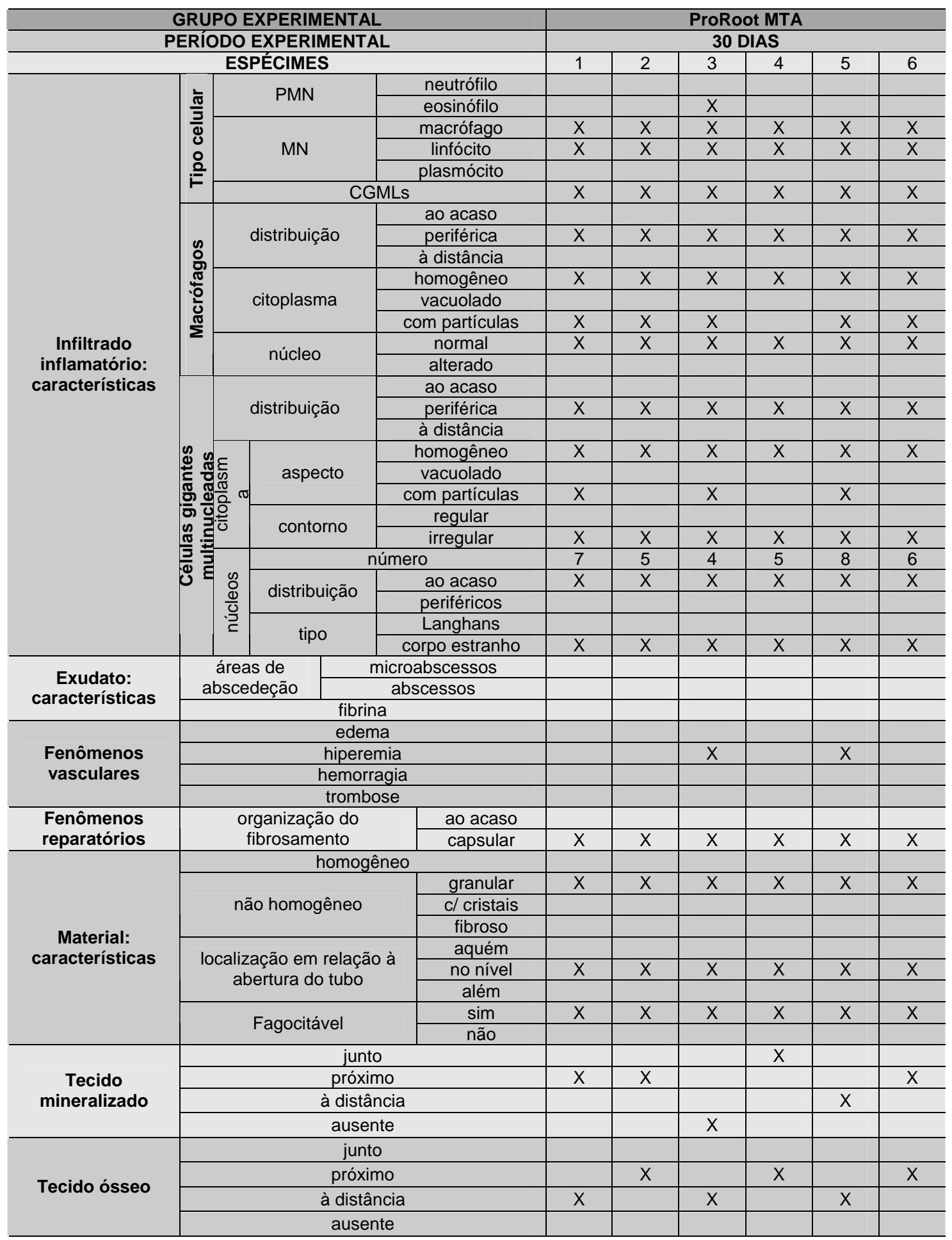




\section{GRUPO II - EXPERIMENTAL - TUBO COM PROROOT MTA - 30 DIAS}

Figura 30 A - Aspecto microscópico panorâmico da transição entre os terços médio e apical do alvéolo dentário, evidenciando a resposta tecidual ao implante de tubo de polietileno preenchido com 0 ProRoot MTA.

Figura 30 B - Características da estreita faixa de tecido mineralizado interposta entre o material e o tecido conjuntivo. Notar a presença de delicadas trabéculas ósseas neorformadas em estádio de mineralização.

Figura 30 C - Nota-se, em maior aumento, o estádio organizacional do tecido subjacente ao material, que apresenta áreas em fase de mineralização e outras já mineralizadas, inclusive, com a presença de osteócitos.

Figura 30 D - Observa-se, em maior aumento, o tecido conjuntivo subjacente à faixa de mineralização, apresentando grande quantidade de matriz colagênica de permeio às células fibroblásticas.

Figura 30 E - Nota-se, em maior aumento, a presença do MTA em meio ao material eosinofílico hialino, subjacente e, em contato com o mesmo, destaca-se a faixa de tecido osteóide neoformado. Imediatamente abaixo desta faixa, observa-se que o tecido conjuntivo apresenta alta celularidade. 


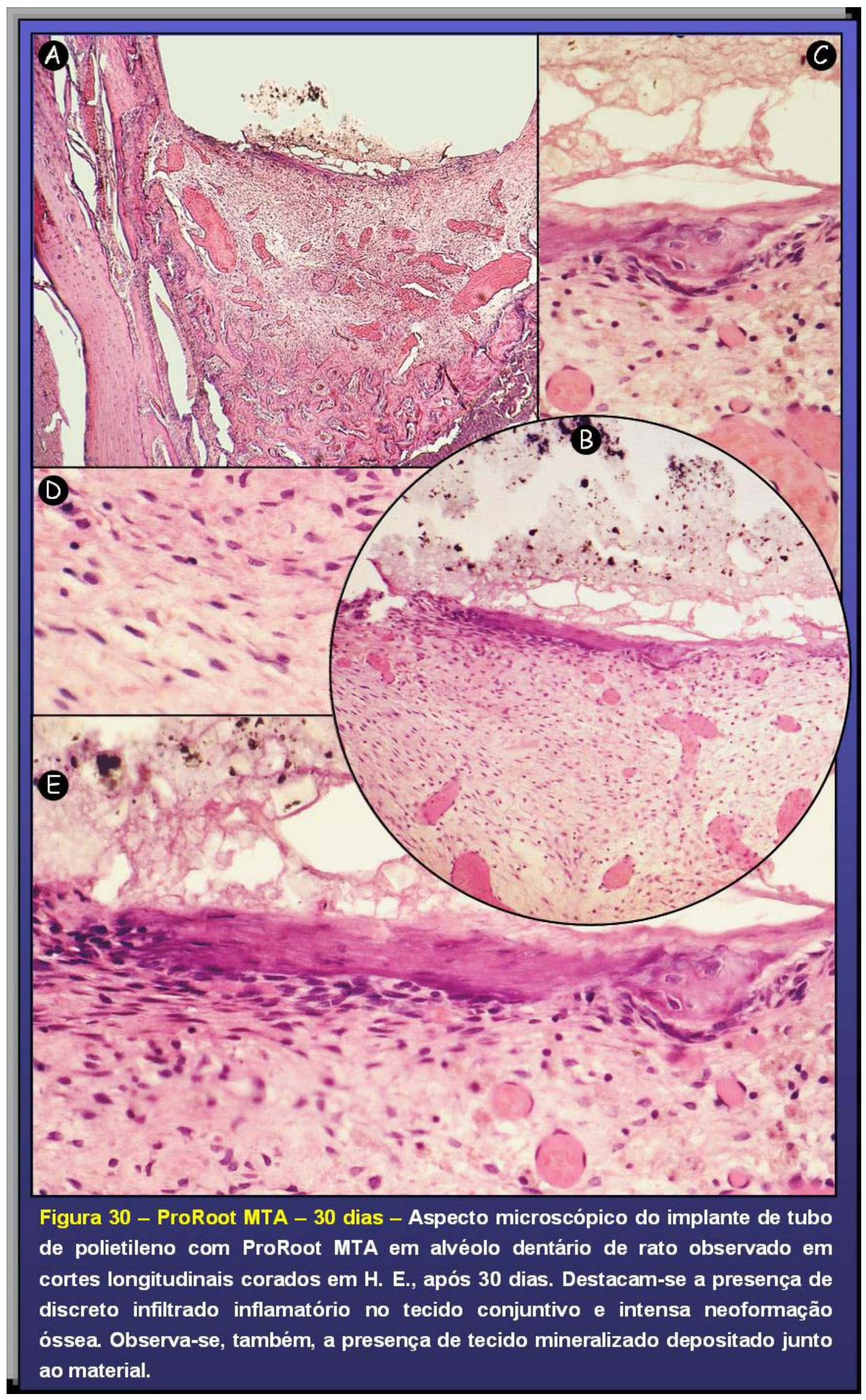




\section{GRUPO III - EXPERIMENTAL - TUBO COM MBPC - 30 DIAS}

Evidenciou-se, na interface com o material, a presença de tecido conjuntivo densamente organizado, característico do estádio final do reparo alveolar. Esse tecido, na maioria dos espécimes, caracterizou-se pela sua celularidade e matriz extracelular bem distribuídos e, também, pela ausência de infiltrado inflamatório. Em um dos espécimes, observou-se a formação de tecido ósseo em contato direto com o material, que caracterizou-se por apresentar avançado estádio de mineralização (Fig. 31 A). Interposto, uma delgada faixa basofílica, provavelmente, devido à afinidade tintorial ao cálcio, também foi visualizada (Fig. 31 B).

Em outros espécimes, notou-se a proximidade do tecido ósseo com o MBPc. Interposto, observou-se delgada faixa de tecido conjuntivo, que apresentava contato direto entre fibroblastos e o material. Destacou-se, ainda, a ausência de células macrofágicas inflamatórias mono ou multinucleadas (Fig. $31 \mathrm{~F}, \mathrm{G}$ ).

$\mathrm{Na}$ região intermediária, entre o material e o fundo do alvéolo, notou-se intensa neoformação óssea que caracterizou avançado estádio de mineralização, com linhas de reversão, numerosos osteócitos em seu interior e osteoblastos ao redor (Fig. 31 C,E).

Próximo ao fundo do alvéolo, notou-se tecido ósseo maduro, que foi caracterizado pela presença de espessas trabéculas ósseas, vasos sangüíneos calibrosos, alguns apresentando hiperemia, outros hemorragia, em meio ao tecido conjuntivo bem organizado. 
Observou-se, em todos os espécimes, a presença de macrófagos, linfócitos e células gigantes multinucleadas inflamatórias, enquanto que, eosinófilos em apenas um. Neutrófilos e plasmócitos não estavam presentes. Quanto aos macrófagos, notou-se distribuição periférica, citoplasmas homogêneos e núcleos normais, sendo que, em quatro espécimes, os citoplasmas apresentaram-se com partículas. Em relação às células gigantes multinucleadas inflamatórias, observou-se, em todos os espécimes, distribuição periférica, citoplasmas homogêneos, de contorno irregular e núcleos distribuídos ao acaso. A presença de partículas foi observada, em um, dos cinco espécimes.

Não se observou, quanto ao exudato, áreas de abscedeção nem a presença de fibrina próximo ao material em nenhum dos espécimes, enquanto que, quanto aos fenômenos vasculares, observou-se hemorragia em dois espécimes e hiperemia em um. Os fenômenos reparatórios, assim como, nos outros dois grupos, notou-se organização do fibrosamento de características capsulares.

Quanto às características do material, observou-se que o mesmo não apresentou homogeneidade, sendo granular e fagocitável, e sua localização se ateve ao nível da abertura do tubo em todos os espécimes.

Quanto à presença de tecido mineralizado, observou-se mineralização em todos os espécimes, localizadas, em um, junto, em outro, próximo, e em 4 espécimes, à distância do material. Tecido ósseo estava presente em 4 espécimes, localizados, em um, junto, em outro, próximo e, em 2, à distância.

Todos esses eventos microscópicos observados estão dispostos na tabela 14 . 
Tabela 14 - Grupo MBPc - 30 dias - Descrição atribuída aos eventos microscópicos observados nos espécimes analisados

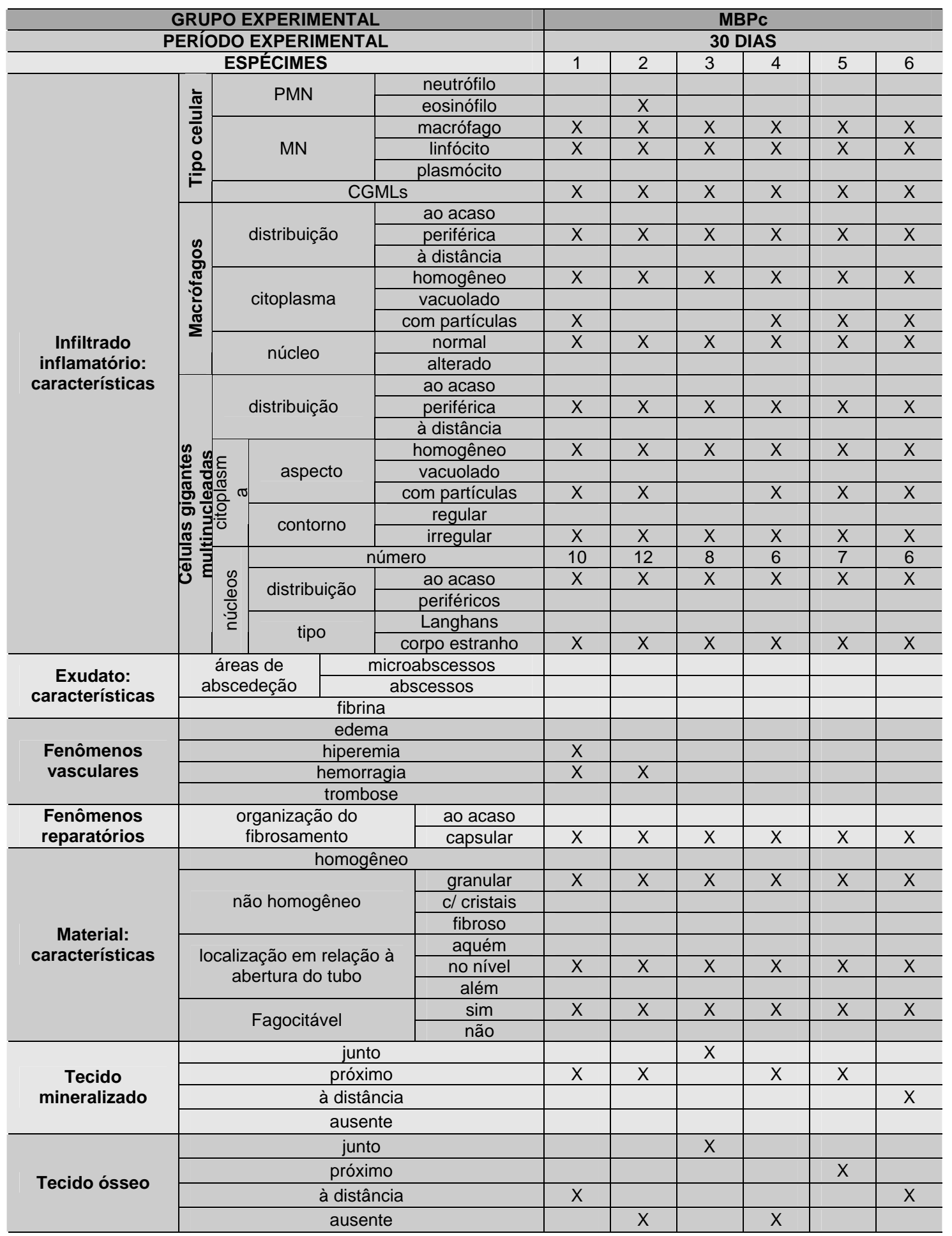




\section{GRUPO III - EXPERIMENTAL - TUBO COM MBPC - 30 DIAS}

Figura 31 A - Aspecto microscópico panorâmico da transição entre o terço médio e apical do alvéolo dentário, evidenciando a resposta tecidual ao implante de tubos de polietileno preenchidos com o MBPC.

Figura 31 B - Em um dos espécimes, destaca-se, o contato direto entre o material e o tecido ósseo neoformado. Notar a presença de osteócitos junto à matriz mineralizada e a delgada faixa basofílica interposta entre este tecido e o material.

Figura 31 C - Nota-se a interação do tecido conjuntivo densamente organizado, com o tecido ósseo trabecular neoformado.

Figura 31 D - Aspecto do estádio de organização celular do tecido conjuntivo subjacente ao material.

Figura 31 E - Aspecto do tecido conjuntivo e ósseo localizado entre o tubo e o fundo do alvéolo. Notar a presença de linhas de reversão, osteócitos, osteoblastos e vasos de maior calibre.

Figura 31 F - Em outro espécime, uma delgada faixa de tecido conjuntivo interpõe-se entre o material e o tecido ósseo.

Figura 31 G - Em maior aumento, nota-se a íntima interação entre o tecido conjuntivo e o MBPc e a proximidade do tecido ósseo neoformado. 


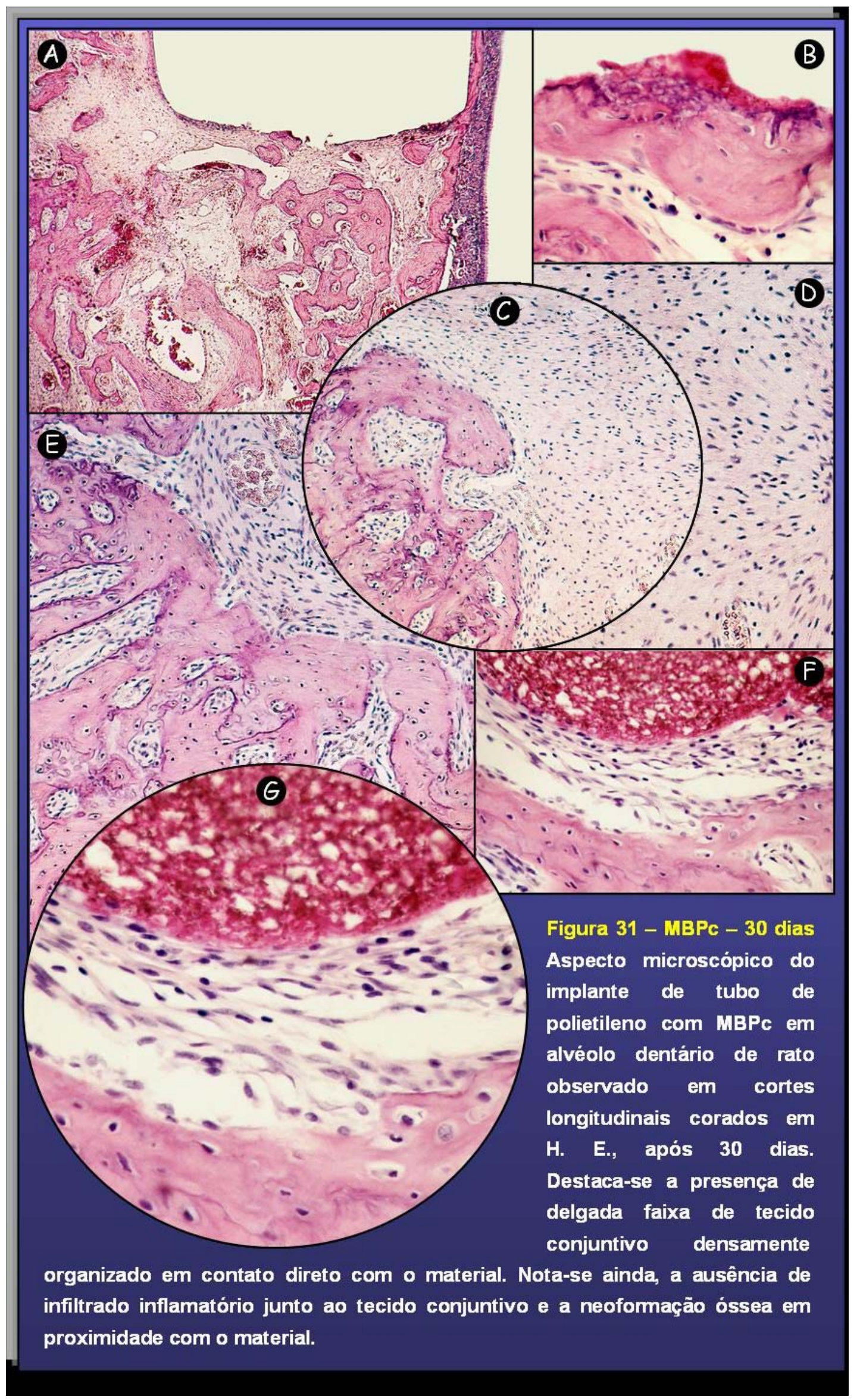




\subsection{ANÁLISE QUANTITATIVA}

Os resultados da análise microscópica quantitativa dos cortes longitudinais semi-seriados do alvéolo dentário, representativos de cada grupo experimental, serão apresentados por meio de uma análise comparativa de acordo com os escores atribuídos aos critérios de avaliação. Levou-se em consideração os tempos pós-operatórios, em função das ocorrências observadas junto ao terço médio e apical dos alvéolos nos diferentes grupos. 


\subsubsection{CRITÉRIO: INFILTRADO INFLAMATÓRIO}

Observou-se, nos períodos iniciais de todos os grupos, a presença de um infiltrado inflamatório de moderado para discreto que, aos 15 dias, evoluiu para somente discreto. Aos 30 dias as características dos tecidos demonstraram discreta reação inflamatória concomitante com 0 reparo do tecido ósseo evidenciado, principalmente, junto ao fundo do alvéolo. Tais características puderam ser avaliadas a partir da análise comparativa entre os grupos, realizada por meio da quantidade de espécimes que exibiam as diversas características.

No grupo controle, aos 7 dias, metade dos espécimes apresentaram discreto infiltrado inflamatório e, a outra metade, moderado. Aos 15 dias, apenas um espécime, foi classificado como moderado. Aos 30 dias, observou-se, em três espécimes, um discreto infiltrado inflamatório e, em um, a inflamação não estava presente (Tabelas 15, 16 e 17).

Nos grupos experimentais as características do infiltrado inflamatório foram semelhantes às do grupo controle, em todos os períodos.

O grupo do MTA apresentou, aos 7 dias, assim como 0 grupo do MBPc, apenas um espécime com moderado infiltrado inflamatório, e os outros cinco, foram classificados como discreto. Aos 15 dias, observouse dois espécimes com quadro inflamatório moderado, três com discreto e, um, com ausente, no grupo do MTA, enquanto que, no grupo do MBPc, apenas um espécime foi classificado como moderado, um como ausente, e os outros quatro como discreto. Aos 30 dias, o processo de reparo encontrou-se em um estádio mais avançado, em ambos os grupos experimentais, onde foi possível constatar, em quatro espécimes, discreto infiltrado inflamatório e, em dois, a ausência do mesmo (Tabelas 15, 16 e 17).

Constatou-se que todos os três grupos, ao longo do tempo, apresentaram o processo de reparo cada vez mais maturo, caracterizado pela diminuição da quantidade de células inflamatórias (Fig. 32). 
$\mathrm{Na}$ maioria dos períodos experimentais, verificou-se a presença de tecido conjuntivo discretamente organizado em torno dos materiais testados. Inicialmente, tal tecido era desorganizado, composto predominantemente por fibroblastos jovens, vasos neoformados e com pouca quantidade de fibras colágenas. Contudo, com o passar do tempo, ele foi se tornando cada vez mais organizado, menos celularizado, com feixes de fibras colágenas densas e paralelas entre si (Fig. 32). 
Tabela 15 - Critério infiltrado inflamatório - 7 dias - Escores atribuídos aos eventos microscópicos observados nos espécimes analisados

\begin{tabular}{|c|c|c|c|c|c|c|c}
\hline GRUPOS IESPÉCIMES & 1 & 2 & 3 & 4 & 5 & 6 & MÉDIAS \\
\hline CONTROLE & 2 & 3 & 3 & 2 & & & 2,50 \\
\hline MTA & 2 & 2 & 2 & 3 & 2 & 2 & 2,16 \\
\hline MBPc & 2 & 2 & 3 & 2 & 2 & 2 & 2,16 \\
\hline
\end{tabular}

Tabela 16 - Critério infiltrado inflamatório - 15 dias - Escores atribuídos aos eventos microscópicos observados nos espécimes analisados

\begin{tabular}{|c|c|c|c|c|c|c|c}
\hline GRUPOS /ESPÉCIMES & 1 & 2 & 3 & 4 & 5 & 6 & MÉDIAS \\
\hline CONTROLE & 2 & 3 & 2 & 2 & & & 2,25 \\
\hline MTA & 2 & 3 & 3 & 2 & 2 & 1 & 2,16 \\
\hline MBPC & 3 & 1 & 2 & 2 & 2 & 2 & 2,00 \\
\hline
\end{tabular}

Tabela 17 - Critério infiltrado inflamatório - 30 dias - Escores atribuídos aos eventos microscópicos observados nos espécimes analisados

\begin{tabular}{|c|c|c|c|c|c|c|c}
\hline GRUPOS /ESPÉCIMES & 1 & 2 & 3 & 4 & 5 & 6 & MÉDIAS \\
\hline CONTROLE & 2 & 2 & 2 & 1 & & & 1,75 \\
\hline MTA & 1 & 2 & 2 & 2 & 2 & 1 & 1,66 \\
\hline MBPC & 2 & 2 & 1 & 2 & 1 & 2 & 1,66 \\
\hline
\end{tabular}

Figura 32 - Gráfico representativo das médias dos escores atribuídos ao infiltrado inflamatório de acordo com os períodos de observação

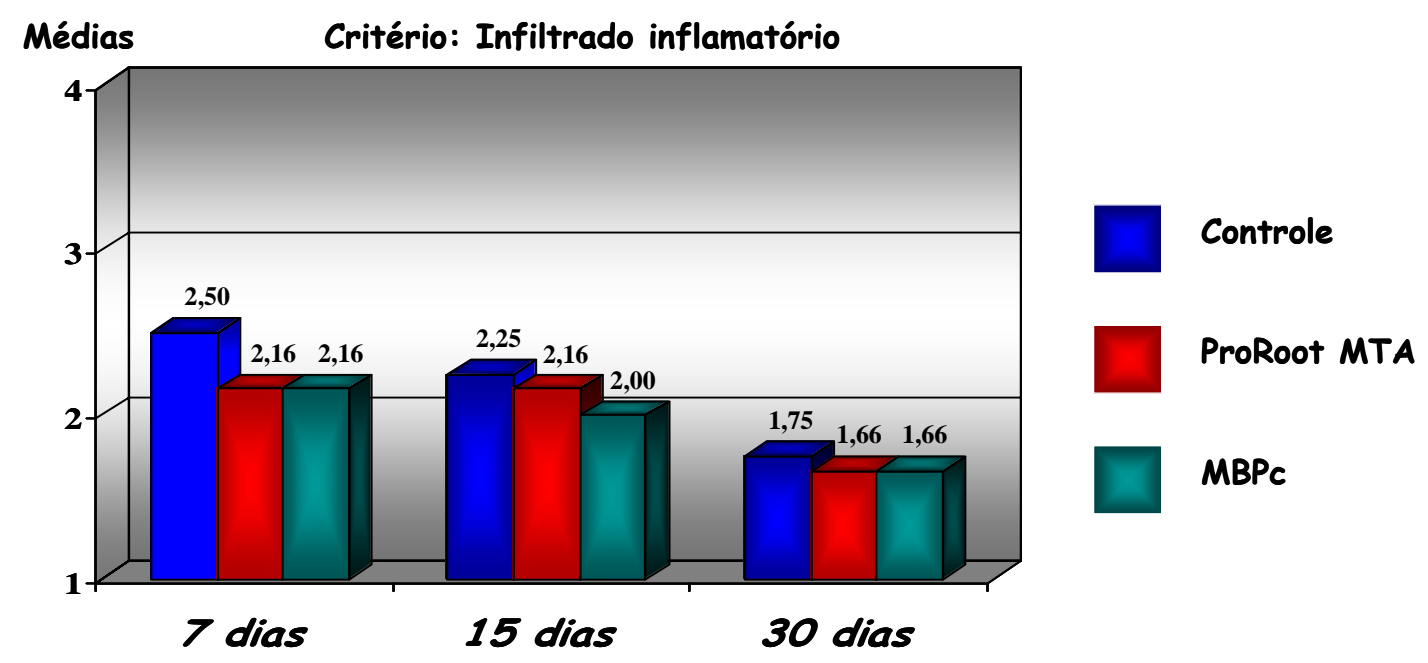




\subsubsection{CRITÉRIO: DENSIDADE DE FIBROBLASTOS JOVENS}

Os fenômenos reparatórios puderam ser avaliados de acordo com os critérios estabelecidos e os escores atribuídos a cada espécime, analisados de forma comparativa entre os grupos (Fig. 33).

Em sendo assim, quanto à densidade de fibroblastos jovens, o grupo controle, aos 7 dias, apresentou três espécimes com características classificadas como baixa e, em um, como média. Aos 15 dias, todos os espécimes apresentaram características classificadas como baixa, enquanto que, aos 30 dias, três espécimes apresentaram-na como baixa e, em um, não se detectou a presença de células fibroblásticas jovens (Tabelas 18, 19 e 20).

Nos grupos experimentais, as semelhanças, mais uma vez, foram visualizadas.

Aos 7 dias, o grupo do MTA apresentou uma densidade fibroblástica classificada como média em apenas um espécime e, em todos os outros, como baixa. Já, o MBPc, apresentou os seis espécimes classificados como baixa, nesse período. Aos 15 dias, o MTA apresentou um espécime com média densidade de fibroblastos jovens, quatro com baixa e, em um, as células fibroblásticas jovens não estavam presentes.

No grupo do MBPc não se observou densidade média de fibroblastos jovens, sendo classificada, em cinco espécimes, como baixa e, em um, as células fibroblásticas não estavam presentes. Notou-se, aos 30 dias, uma piora, quanto a esse critério, no grupo do MTA, evidenciado por, metade dos espécimes apresentar características de média densidade de células fibroblásticas e, a outra metade, baixa. Em contraste, no grupo do MBPc, evidenciou-se quatro espécimes com densidade baixa e, em dois, não havia a presença de células fibroblásticas jovens (Tabelas 18, 19 e 20 e Fig. 33). 
Tabela 18 - Critério densidade de fibroblastos jovens - 7 dias - Escores atribuídos aos eventos microscópicos observados nos espécimes analisados

\begin{tabular}{|c|c|c|c|c|c|c|c}
\hline GRUPOS IESPÉCIMES & 1 & 2 & 3 & 4 & 5 & 6 & MÉDIAS \\
\hline CONTROLE & 2 & 2 & 3 & 2 & & & 2,25 \\
\hline MTA & 2 & 2 & 2 & 3 & 2 & 2 & 2,16 \\
\hline MBPc & 2 & 2 & 2 & 2 & 2 & 2 & 2,00 \\
\hline
\end{tabular}

Tabela 19 - Critério densidade de fibroblastos jovens- 15 dias - Escores atribuídos aos eventos microscópicos observados nos espécimes analisados

\begin{tabular}{|c|c|c|c|c|c|c|c}
\hline GRUPOS IESPÉCIMES & 1 & 2 & 3 & 4 & 5 & 6 & MÉDIAS \\
\hline CONTROLE & 2 & 2 & 2 & 2 & & & 2,00 \\
\hline MTA & 2 & 3 & 2 & 2 & 2 & 1 & 2,00 \\
\hline MBPc & 2 & 1 & 2 & 2 & 2 & 2 & 1,83 \\
\hline
\end{tabular}

Tabela 20 - Critério densidade de fibroblastos jovens-30 dias - Escores atribuídos aos eventos microscópicos observados nos espécimes analisados

\begin{tabular}{|c|c|c|c|c|c|c|c}
\hline GRUPOS /ESPÉCIMES & 1 & 2 & 3 & 4 & 5 & 6 & MÉDIAS \\
\hline CONTROLE & 2 & 1 & 2 & 2 & & & 1,75 \\
\hline MTA & 2 & 3 & 2 & 3 & 2 & 3 & 2,50 \\
\hline MBPC & 2 & 2 & 1 & 2 & 1 & 2 & 1,66 \\
\hline
\end{tabular}

Figura 33 - Gráfico representativo das médias dos escores atribuídos a densidade de fibroblastos jovens de acordo com os períodos de observação

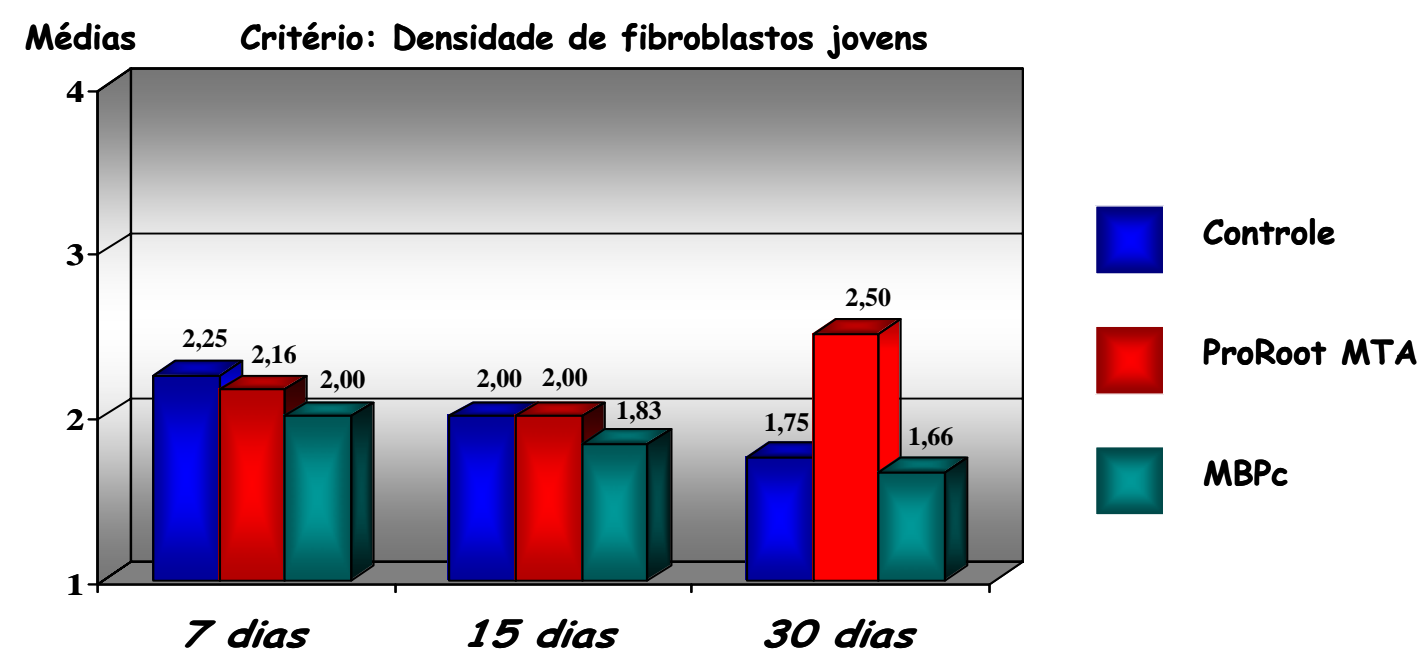




\subsubsection{CRITÉRIO: DENSIDADE ANGIOBLÁSTICA}

Quanto ao critério densidade angioblástica, observou-se, no grupo controle, aos 7 dias, três espécimes com média densidade e, em um, como baixa. Aos 15 dias, a densidade angioblástica foi classificada como média, em metade dos espécimes e, na outra metade, como baixa. Aos 30 dias, dois espécimes foram classificados como média, um espécime como baixa e, outro, havia tecido conjuntivo maduro com alta quantidade de fibras colágenas e ausência de vasos sangüíneos neoformados (Tabelas 21, 22 e 23 e Fig. 34).

Notou-se aos 7 dias que, com o MTA, apenas um espécime apresentou características que o classificou em média densidade angioblástica. Dos outros cinco espécimes, foram classificados como baixa, quatro deles e, no outro, não se detectou a presença de vasos sangüíneos neoformados. No grupo do MBPc, observou-se também que, em um espécime, havia tecido conjuntivo maduro com alta quantidade de fibras colágenas e ausência de vasos sangüíneos neoformados. Nos outros cinco espécimes, esse critério foi classificado como baixa, em três deles e média, em dois. Aos 15 dias, os dois grupos experimentais apresentaram melhores níveis para esse critério. No grupo do MTA evidenciou-se, em três espécimes, média densidade angioblástica, em um, baixa e, em dois, não se encontrou vasos sangüíneos neoformados. Comparando ao MBPc, constatou-se, apenas um espécime, classificado como média, três como baixa e, em dois, havia tecido conjuntivo maduro com alta quantidade de fibras colágenas e ausência de neoformação angioblástica. Aos 30 dias observou-se, no grupo do MTA a presença de média densidade angioblástica, em dois espécimes e baixa, em quatro. Já, no grupo do MBPc, metade dos espécimes foi classificado como ausente, por apresentar tecido conjuntivo maduro rico em fibras colágenas e ausência de neoformação angioblástica. Nos outros dois, classificou-se a densidade como baixa e, apenas um espécime, foi classificado como média (Tabelas 21, 22 e 23 e Fig. 34). 
Tabela 21 - Critério densidade angioblástica - 7 dias - Escores atribuídos aos eventos microscópicos observados nos espécimes analisados

\begin{tabular}{|c|c|c|c|c|c|c|c}
\hline GRUPOS IESPÉCIMES & 1 & 2 & 3 & 4 & 5 & 6 & MÉDIAS \\
\hline CONTROLE & 3 & 2 & 3 & 3 & & & 2,75 \\
\hline MTA & 1 & 2 & 2 & 2 & 3 & 2 & 2,00 \\
\hline MBPc & 2 & 2 & 3 & 3 & 1 & 2 & 2,16 \\
\hline
\end{tabular}

Tabela 22 - Critério densidade angioblástica - 15 dias - Escores atribuídos aos eventos microscópicos observados nos espécimes analisados

\begin{tabular}{|c|c|c|c|c|c|c|c}
\hline GRUPOS IESPÉCIMES & 1 & 2 & 3 & 4 & 5 & 6 & MÉDIAS \\
\hline CONTROLE & 3 & 3 & 2 & 2 & & & 2,50 \\
\hline MTA & 1 & 3 & 3 & 1 & 3 & 2 & 2,16 \\
\hline MBPC & 3 & 1 & 1 & 2 & 2 & 2 & 1,83 \\
\hline
\end{tabular}

Tabela 23 - Critério densidade angioblástica - 30 dias - Escores atribuídos aos eventos microscópicos observados nos espécimes analisados

\begin{tabular}{|c|c|c|c|c|c|c|c}
\hline GRUPOS IESPÉCIMES & 1 & 2 & 3 & 4 & 5 & 6 & MÉDIAS \\
\hline CONTROLE & 2 & 3 & 3 & 1 & & & 2,25 \\
\hline MTA & 2 & 2 & 3 & 2 & 3 & 2 & 2,33 \\
\hline MBPC & 2 & 1 & 1 & 3 & 1 & 2 & 1,66 \\
\hline
\end{tabular}

Figura 34 - Gráfico representativo das médias dos escores atribuídos a densidade angioblástica de acordo com os períodos de observação

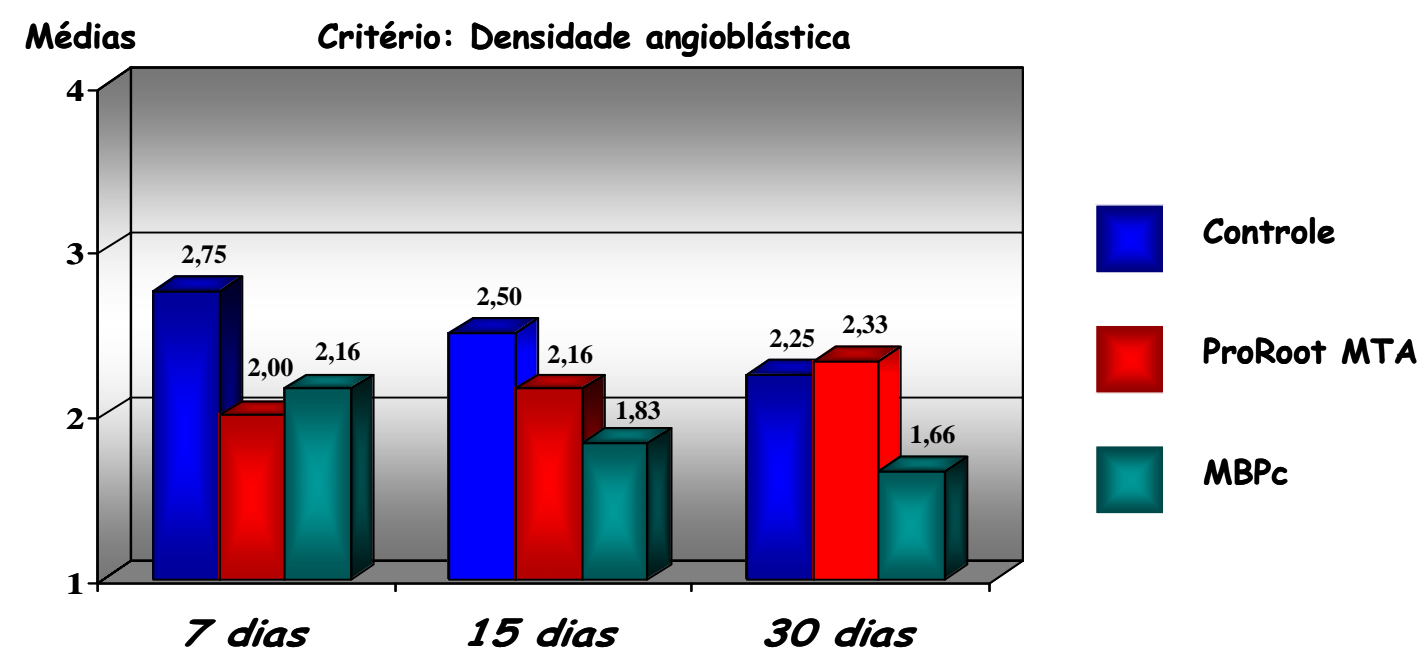




\subsubsection{CRITÉRIO: DENSIDADE DO FIBROSAMENTO}

A densidade do fibrosamento foi avaliada comparativamente entre os grupos controle e experimentais de acordo com o período de observação, levando-se em consideração a quantidade de espécimes que exibiam maior ou menor quantidade de fibras colágenas, em proporção à celularidade encontrada (Fig. 35).

O grupo controle, aos 7 dias, exibiu, em metades dos espécimes, densidade média e, na outra metade, baixa. Aos 15 dias, apenas um espécime exibiu densidade baixa e, os outros três, média. Aos 30 dias, todos os espécimes, exibiram densidade do fibrosamento média (Tabelas 24,25 e 26).

Nos dois grupos experimentais, aos 7 dias, evidenciou-se, apenas um espécime com maior quantidade de fibras em relação à quantidade de células, classificando-o, como baixa densidade. Todos os outros espécimes foram classificados como média densidade de fibrosamento. Aos 15 dias, mais uma vez, os grupos experimentais foram semelhantes, exibindo, em um espécime, baixa densidade, em quatro, média e, em um, havia alta quantidade de fibras colágenas e baixa quantidade de células, que classificaram-no como alta densidade. Aos 30 dias observaram-se pequenas diferenças entre os grupos experimentais, que revelaram, em todos os espécimes com MTA média densidade do fibrosamento. Já com o MBPc, cinco espécimes, exibiram média densidade do fibrosamento e, em um, a densidade foi considerada alta (Tabelas 24, 25 e 26).

Constatou-se que, quanto a esse critério, todos os três grupos, com o passar do tempo, apresentaram maturação no processo de reparo, caracterizada por uma diminuição da quantidade de células e um aumento da quantidade de fibras (Tabelas 24, 25 e 26 e Fig. 35). 
Tabela 24 - Critério densidade do fibrosamento - 7 dias - Escores atribuídos aos eventos microscópicos observados nos espécimes analisados

\begin{tabular}{|c|c|c|c|c|c|c|c}
\hline GRUPOS IESPÉCIMES & 1 & 2 & 3 & 4 & 5 & 6 & MÉDIAS \\
\hline CONTROLE & 3 & 2 & 3 & 2 & & & 2,50 \\
\hline MTA & 2 & 2 & 2 & 3 & 2 & 2 & 2,16 \\
\hline MBPC & 2 & 2 & 3 & 2 & 2 & 2 & 2,16 \\
\hline
\end{tabular}

Tabela 25 - Critério densidade do fibrosamento - 15 dias - Escores atribuídos aos eventos microscópicos observados nos espécimes analisados

\begin{tabular}{|c|c|c|c|c|c|c|c}
\hline GRUPOS IESPÉCIMES & 1 & 2 & 3 & 4 & 5 & 6 & MÉDIAS \\
\hline CONTROLE & 3 & 2 & 2 & 2 & & & 2,25 \\
\hline MTA & 2 & 2 & 3 & 2 & 2 & 1 & 2,00 \\
\hline MBPC & 3 & 1 & 2 & 2 & 2 & 2 & 2,00 \\
\hline
\end{tabular}

Tabela 26 - Critério densidade do fibrosamento -30 dias - Escores atribuídos aos eventos microscópicos observados nos espécimes analisados

\begin{tabular}{|c|c|c|c|c|c|c|c}
\hline GRUPOS IESPÉCIMES & 1 & 2 & 3 & 4 & 5 & 6 & MÉDIAS \\
\hline CONTROLE & 2 & 2 & 2 & 2 & & & 2,00 \\
\hline MTA & 2 & 2 & 2 & 2 & 2 & 2 & 2,00 \\
\hline MBPC & 2 & 2 & 1 & 2 & 2 & 2 & 1,83 \\
\hline
\end{tabular}

Figura 35 - Gráfico representativo das médias dos escores atribuídos a densidade do fibrosamento de acordo com os períodos de observação

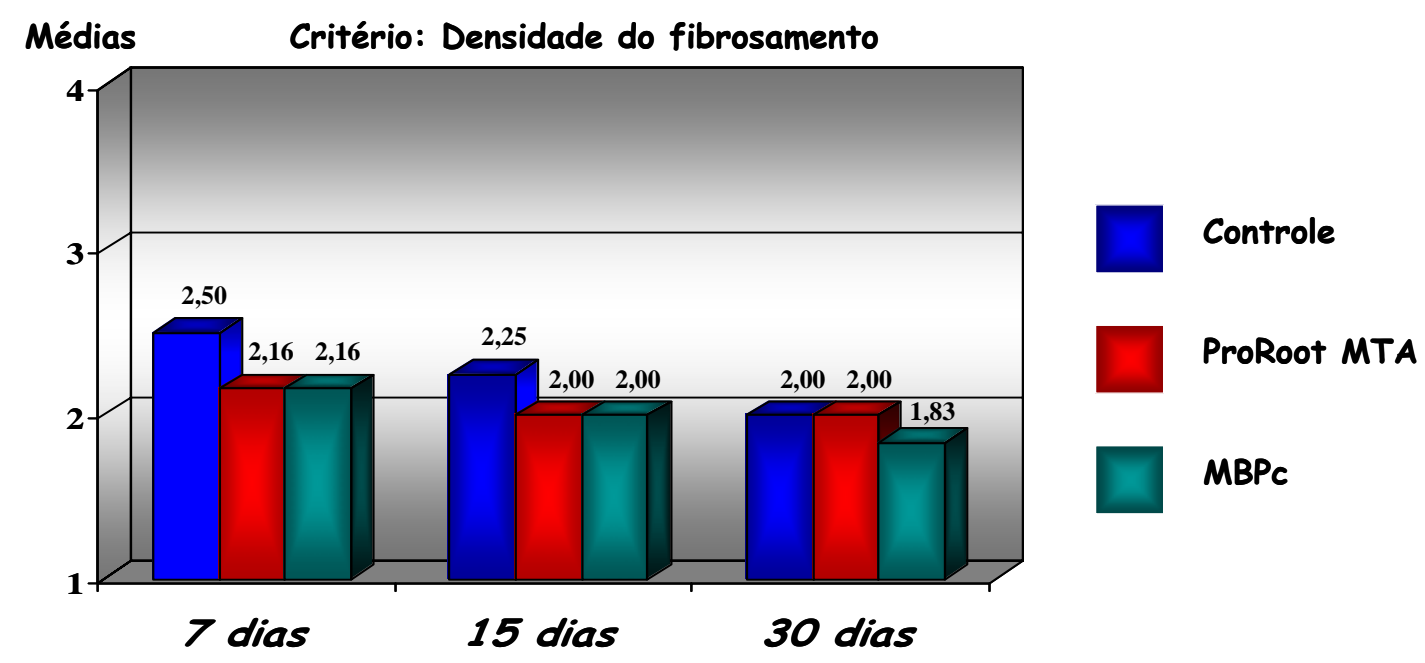




\subsubsection{CRITÉRIO: PRESENÇA E LOCALIZAÇÃO DA DEPOSIÇÃO DE TECIDO MINERALIZADO}

O critério tecido mineralizado foi avaliado comparativamente entre os grupos experimentais levando-se em consideração o número de espécimes e a localização onde a presença desse tecido foi evidenciada (Fig. 36).

No grupo controle, não foi observado a presença de tecido mineralizado a não ser o ósseo, em nenhum dos tempos pós-operatórios. No grupo do MTA observou-se que, aos 7 dias, a mineralização estava presente e localizada próxima ao material, em metade dos espécimes e, no grupo do MBPc, em apenas um espécime. Aos 15 dias notou-se mineralização em contato com o MTA, em metade dos espécimes, enquanto que, com 0 MBPc, a mineralização não foi evidenciada nesse período. Aos 30 dias, no grupo com MTA, observou-se mineralização em cinco dos seis espécimes, sendo localizada, em contato com o material, em um espécime, próxima ao material em três espécimes e, em outro, localizada à distância. Por outro lado, no grupo do MBPc, observou-se à presença de mineralização, em todos os espécimes. Assim como, no grupo do MTA, em um espécime a localização da mineralização foi junto ao material. Nos outros espécimes, foram localizadas mineralizações próxima ao MBPc em quatro casos e, em um, à distância (Tabelas 27, 28 e 29 e Fig. 36). 
Tabela 27 - Critério tecido mineralizado - 7 dias - Escores atribuídos aos eventos microscópicos observados nos espécimes analisados

\begin{tabular}{|c|c|c|c|c|c|c|c}
\hline GRUPOS IESPÉCIMES & 1 & 2 & 3 & 4 & 5 & 6 & MÉDIAS \\
\hline CONTROLE & 4 & 4 & 4 & 4 & & & 4,00 \\
\hline MTA & 4 & 2 & 2 & 2 & 4 & 4 & 3,00 \\
\hline MBPc & 4 & 4 & 4 & 2 & 4 & 4 & 3,66 \\
\hline
\end{tabular}

Tabela 28 - Critério tecido mineralizado - 15 dias - Escores atribuídos aos eventos microscópicos observados nos espécimes analisados

\begin{tabular}{|c|c|c|c|c|c|c|c}
\hline GRUPOS IESPÉCIMES & 1 & 2 & 3 & 4 & 5 & 6 & MÉDIAS \\
\hline CONTROLE & 4 & 4 & 4 & 4 & & & 4,00 \\
\hline MTA & 1 & 4 & 1 & 4 & 1 & 4 & 2,50 \\
\hline MBPc & 4 & 4 & 4 & 4 & 4 & 4 & 4,00 \\
\hline
\end{tabular}

Tabela 29 - Critério tecido mineralizado - 30 dias - Escores atribuídos aos eventos microscópicos observados nos espécimes analisados

\begin{tabular}{|c|c|c|c|c|c|c|c}
\hline GRUPOS /ESPÉCIMES & 1 & 2 & 3 & 4 & 5 & 6 & MÉDIAS \\
\hline CONTROLE & 4 & 4 & 4 & 4 & & & 4,00 \\
\hline MTA & 2 & 2 & 4 & 1 & 3 & 2 & 2,33 \\
\hline MBPC & 2 & 2 & 1 & 2 & 2 & 3 & 2,00 \\
\hline
\end{tabular}

Figura 36 - Gráfico representativo das médias dos escores atribuídos a presença e localização da deposição de tecido mineralizado de acordo com os períodos de observação

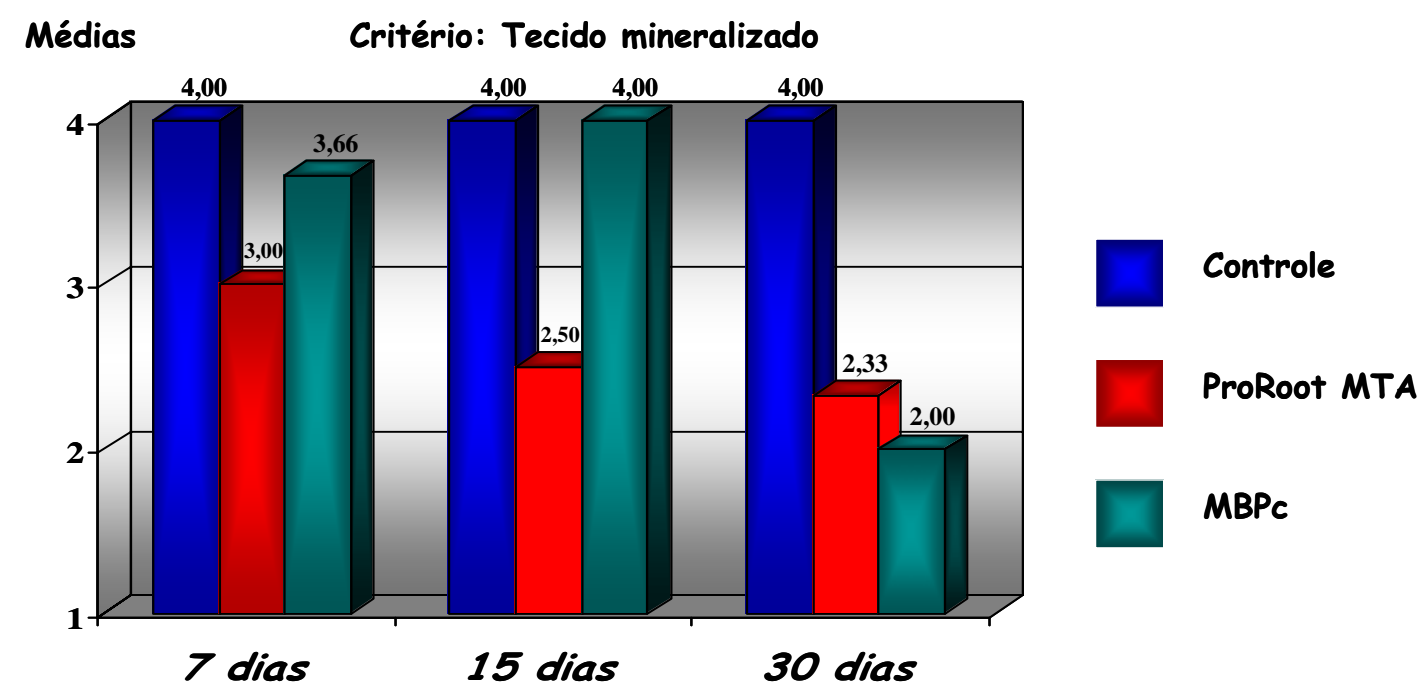




\subsubsection{CRITÉRIO: PRESENÇA E LOCALIZAÇÃO DA DEPOSIÇÃO DE TECIDO ÓSSEO}

O critério tecido ósseo foi avaliado comparativamente entre os grupos controle e experimentais levando-se em consideração o número de espécimes e a localização onde a presença desse tecido foi evidenciada (Fig. 37).

No grupo controle, aos 7 dias que, não foram encontradas evidencias de deposição de tecido ósseo em nenhum dos espécimes. Aos 15 dias, metade dos espécimes, já apresentava a deposição de tecido ósseo, à distância do tubo e, aos 30 dias todos os espécimes evidenciaram neoformação óssea, sendo localizada em três, à distância e, em um, próxima ao tubo (Tabelas 30, 31 e 32).

No grupo do MTA, aos 7 dias, observou-se a deposição de tecido ósseo, localizado próximo ao material, em apenas um espécime, enquanto que, no grupo do $\mathrm{MBPc}$, todos os espécimes apresentaram tecido ósseo à distância do material. Aos 15 dias, observou-se que, com o MTA, o tecido ósseo, formou-se em metade dos espécimes e, foi localizado, em dois casos, à distância e, em um, próximo ao material. Já, com o MBPc, notou-se que, o tecido ósseo estava presente em cinco dos seis espécimes, sendo localizado, à distância, em dois casos e, próximo, em três. Aos 30 dias, no grupo do MTA, a deposição de tecido ósseo foi encontrada em todos os espécimes e, localizada em metade deles, à distância, e na outra metade, próxima ao material. No grupo do MBPc, a deposição desse tecido foi encontrada em apenas quatro espécimes, localizada, à distância, em dois, próxima, em um, e junta, também em um (Tabelas 30, 31 e 32 e Fig. 37). 
Tabela 30 - Critério tecido ósseo - 7 dias - Escores atribuídos aos eventos microscópicos observados nos espécimes analisados

\begin{tabular}{|c|c|c|c|c|c|c|c}
\hline GRUPOS IESPÉCIMES & 1 & 2 & 3 & 4 & 5 & 6 & MÉDIAS \\
\hline CONTROLE & 4 & 4 & 4 & 4 & & & 4,00 \\
\hline MTA & 2 & 4 & 4 & 4 & 4 & 4 & 3,66 \\
\hline MBPc & 3 & 3 & 3 & 3 & 3 & 3 & 3,00 \\
\hline
\end{tabular}

Tabela 31 - Critério tecido ósseo - 15 dias - Escores atribuídos aos eventos microscópicos observados nos espécimes analisados

\begin{tabular}{|c|c|c|c|c|c|c|c}
\hline GRUPOS /ESPÉCIMES & 1 & 2 & 3 & 4 & 5 & 6 & MÉDIAS \\
\hline CONTROLE & 4 & 4 & 3 & 3 & & & 3,50 \\
\hline MTA & 4 & 4 & 4 & 3 & 3 & 2 & 3,33 \\
\hline MBPC & 3 & 2 & 2 & 2 & 4 & 3 & 2,66 \\
\hline
\end{tabular}

Tabela 32 - Critério tecido ósseo - 30 dias - Escores atribuídos aos eventos microscópicos observados nos espécimes analisados

\begin{tabular}{|c|c|c|c|c|c|c|c}
\hline GRUPOS IESPÉCIMES & 1 & 2 & 3 & 4 & 5 & 6 & MÉDIAS \\
\hline CONTROLE & 2 & 3 & 3 & 3 & & & 2,75 \\
\hline MTA & 3 & 2 & 3 & 2 & 3 & 2 & 2,50 \\
\hline MBPC & 3 & 4 & 1 & 4 & 2 & 3 & 2,83 \\
\hline
\end{tabular}

Figura 37 - Gráfico representativo das médias dos escores atribuídos a presença e localização da deposição de tecido ósseo de acordo com os períodos de observação

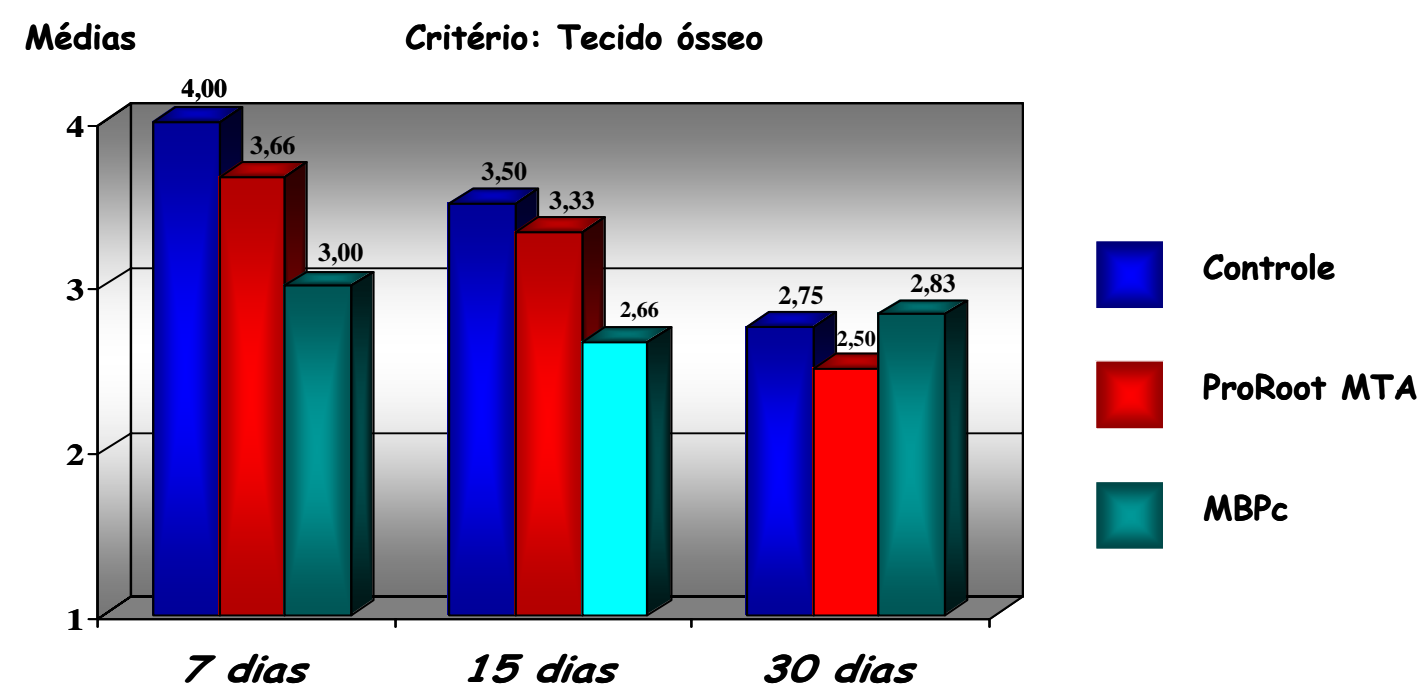


Diante dos dados atribuídos, pelos dois observadores, a cada um dos eventos infamatórios e reparatórios, efetuou-se o teste Kappa, para analisar a confiabilidade das leituras realizadas. Os valores obtidos, por meio desse teste, para cada fenômeno inflamatório e reparatório avaliado aos 7, 15 e 30 dias, foram classificados segundo os critérios dos níveis de concordância de coeficiente Kappa, abaixo relacionados:

Tabela 33 - Critérios de classificação dos níveis de concordância de coeficiente Kappa

\begin{tabular}{c|c}
\hline Coeficiente Kappa & Nível de concordância \\
\hline$<0,00$ & Baixo \\
\hline $0,00-0,20$ & Médio \\
\hline $0,21-0,40$ & Moderado \\
\hline $0,41-0,60$ & Substancial \\
\hline $0,61-0,80$ & Quase perfeito \\
\hline $0,81-1,00$ & Q \\
\hline
\end{tabular}

O coeficiente de concordância Kappa, bem como, sua classificação, estão expostos na tabela abaixo:

Tabela 34 - Coeficiente de concordância (Kappa) para os fenômenos inflamatório e reparatório nos três períodos analisados

\begin{tabular}{|c|c|c|c|}
\hline $\begin{array}{l}\text { FENÔMENOS } \\
\text { ANALISADOS }\end{array}$ & 7 dias & 15 dias & 30 dias \\
\hline $\begin{array}{l}\text { Intensidade } \\
\text { inflamatória }\end{array}$ & $\begin{array}{c}\text { 0,922875 } \\
\text { quase perfeito }\end{array}$ & $\begin{array}{c}\text { 0,933774 } \\
\text { quase perfeito }\end{array}$ & $\begin{array}{c}0,758389 \\
\text { substancial }\end{array}$ \\
\hline $\begin{array}{c}\text { Densidade de } \\
\text { fibroblastos jovens }\end{array}$ & $\begin{array}{l}0,730660 \\
\text { substancial }\end{array}$ & $\begin{array}{l}0,725750 \\
\text { substancial }\end{array}$ & $\begin{array}{c}\text { 0,841885 } \\
\text { quase perfeito }\end{array}$ \\
\hline $\begin{array}{c}\text { Densidade } \\
\text { angioblástica }\end{array}$ & $\begin{array}{l}0,774708 \\
\text { substancial }\end{array}$ & $\begin{array}{l}\text { 0,683258 } \\
\text { substancial }\end{array}$ & $\begin{array}{l}0,412398 \\
\text { moderado }\end{array}$ \\
\hline $\begin{array}{l}\text { Densidade do } \\
\text { fibrosamento }\end{array}$ & $\begin{array}{l}0,747316 \\
\text { substancial }\end{array}$ & $\begin{array}{c}\text { 0,822469 } \\
\text { quase perfeito }\end{array}$ & $\begin{array}{l}\text { 0,26611 } \\
\text { médio }\end{array}$ \\
\hline
\end{tabular}


Os dados obtidos, uma vez classificados segundo os critérios dos níveis de concordância de coeficiente Kappa, demonstraram nível de concordância "quase perfeito" em 4 testes e nível "substancial" em 6 testes, de uma total de 12 testes efetuados. Entretanto, em duas avaliações, os níveis de concordância, foram "moderado" e "médio" (Tabela 34). Em sendo assim, optou-se, então, por uma nova calibragem dos observadores, com o propósito de se examinar as lâminas onde a concordância não foi satisfatória. Esta segunda análise realizada pelos observadores foi feita em conjunto, tentando chegar a um consenso. Assim, o resultado final da análise foi consistente, não apresentando resultados contraditórios e possibilitando uma análise comparativa entre os grupos experimentais.

Desta forma, os dados obtidos na análise quantitativa por meio da atribuição de escores referentes aos três grupos, foram submetidos à análise de variância (ANOVA) através do modelo não paramétrico de Kruskal-Wallis. Foram realizadas comparações entre os 3 grupos nos três períodos experimentais, levando-se em consideração 5 dos 6 critérios da análise microscópica. O critério referente à deposição de tecido mineralizado foi excluído desta análise, pois, no grupo controle a magnitude deste ítem não pode ser avaliada (Tabelas 35, 36 e 37). 
Tabela 35 - Teste de Kruskal-Wallis para análise do resultado geral entre os 3 grupos (experimentais e controle) no período de 7 dias

\begin{tabular}{c|c|c|c|c}
\hline Grupos & Mediana & Soma de postos & Posto médio & Amostra \\
\hline Controle & 3,0 & 937,5 & 46,8 & 20 \\
\hline MTA & 2,0 & 1245,5 & 41,5 & 30 \\
\hline MBPc & 2,0 & 1057,0 & 35,2 & 30 \\
\hline
\end{tabular}

$\mathrm{HC}=3,870846$

Probabilidade $=0.144363$

Significante para $p<0,05$

Tabela 36 - Teste de Kruskal-Wallis para análise do resultado geral entre os 3 grupos (experimentais e controle) no período de 15 dias

\begin{tabular}{c|c|c|c|c}
\hline Grupos & Mediana & Soma de postos & Posto médio & Amostra \\
\hline Controle & 2,0 & 932,0 & 46,6 & 20 \\
\hline MTA & 2,0 & 1263,0 & 42,1 & 30 \\
\hline MBPc & 2,0 & 1045,0 & 34,8 & 30 \\
\hline
\end{tabular}

$\mathrm{HC}=4.050641$

Probabilidade $=0.131951$

Significante para $p<0,05$ 
Tabela 37 - Teste de Kruskal-Wallis para análise do resultado geral entre os 3 grupos (experimentais e controle) no período de 30 dias

\begin{tabular}{c|c|c|c|c}
\hline Grupos & Mediana & Soma de postos & Posto médio & Amostra \\
\hline Controle & 2,0 & 837,0 & 41,8 & 20 \\
\hline MTA & 2,0 & 1349,0 & 44,9 & 30 \\
\hline MBPc & 2,0 & 1054,0 & 35,1 & 30 \\
\hline
\end{tabular}

$\mathrm{HC}=3.601651$

Probabilidade $=0.165162$

Significante para $p<0,05$

De acordo com os resultados acima expostos, pode-se inferir que os 3 grupos (experimentais e controle) não apresentaram diferenças significantes do ponto de vista estatístico, no período de 7, 15 e 30 dias, pois apresentaram resultado geral semelhante.

Também foi aplicado o Teste de Kruskal-Wallis para os 3 grupos, realizado individualmente, para cada um dos 5 critérios da análise microscópica 1 a 1 (Tabela 38).

Esta análise procurou comparar, entre os grupos, se ocorreu alguma diferença estatisticamente significante quando da avaliação dos eventos microscópicos observados isoladamente. 
Tabela 38 - Teste de Kruskal-Wallis para análise do resultado entre os 3 grupos (experimentais e controle) no período de 7, 15 e 30 dias, para cada um dos 5 critérios da análise microscópica

\begin{tabular}{ll|c|c|c}
\hline \multirow{2}{*}{$\begin{array}{c}\text { CRITÉRIOS DE ANÁLISE } \\
\text { MICROSCÓPICA }\end{array}$} & \multicolumn{3}{c}{ VALOR DE p } \\
\cline { 3 - 5 } & $\mathbf{7 ~ d i a s}$ & $\mathbf{1 5}$ dias & $\mathbf{3 0}$ dias \\
\hline 1. Infiltrado inflamatório & 0.434598 & 0.809925 & 0.955563 \\
\hline 2. & Densidade de fibroblastos jovens & 0.489541 & 0.772644 & $\mathbf{0 . 0 4 8 7 6 0}$ \\
\hline 3. & Densidade angioblástica & 0.198234 & 0.434598 & 0.290603 \\
\hline 4. & Densidade do fibrosamento & 0.434598 & 0.759780 & 0.434598 \\
\hline 5. & Tecido ósseo & $\mathbf{0 . 0 0 9 8 6 2}$ & 0.214024 & 0.659838 \\
\hline
\end{tabular}

Significante para $p<0,05$

De acordo com os resultados acima expostos, pode-se inferir que os 3 grupos (experimentais e controle) apresentaram diferenças significantes do ponto de vista estatístico, quanto ao critério densidade de fibroblastos jovens no período de 30 dias $(p=0.048760)$ e quanto ao critério presença e localização da deposição de tecido ósseo no período de 7 dias (p $=0.009862$ ). Devido a estas diferenças foi, então, aplicado o teste de Dunn para comparações individuais entre os 3 grupos referentes a estes dois critérios (Tabelas 39 e 40).

Tabela 39 - Teste de Dunn para comparações individuais entre os 3 grupos quanto ao critério densidade de fibroblastos jovens no período de $\mathbf{3 0}$ dias

\begin{tabular}{c|c|c|c}
\hline Comparações & Diferença & Valor crítico & Interpretação \\
\hline AXB & -4.8750000 & 7.35704716 & Não signific. \\
\hline AXC & 0.54166667 & 7.35704716 & Não signific. \\
\hline BXC & 5.41666667 & 6.58034303 & Não signific. \\
\hline
\end{tabular}

Nível de significância $=0,05$ 
Apesar do teste de Kruskal-Wallis demonstrar diferenças entre os 3 grupos quanto ao critério densidade de fibroblastos jovens no período de 30 dias, a aplicação do teste de Dunn para comparar individualmente a relação entre os grupos neste período, não detectou diferenças significantes.

Tabela 40 - Teste de Dunn para comparações individuais entre os 3 grupos quanto ao critério presença e localização da deposição do tecido ósseo no período de 7 dias

\begin{tabular}{c|c|c|c}
\hline Comparações & Diferença & Valor crítico & Interpretação \\
\hline AXB & 1.83333333 & 7.35704716 & Não signific. \\
\hline AXC & 7.50000000 & 7.35704716 & Signific. \\
\hline BXC & 5.66666667 & 6.58034303 & Não signific. \\
\hline
\end{tabular}

Nível de significância $=0.05$

A aplicação do teste de Dunn para o critério presença e localização da deposição do tecido ósseo no período de 7 dias demonstrou haver diferenças estatisticamente significantes entre o grupo controle e o MBPc (Tabela 40).

Aos 7 dias, em todos os espécimes do grupo controle não havia ainda sinais de neoformação junto, próximo ou à distância do material retrobturador, já no grupo do MBPc todos os espécimes apresentaram formação óssea à distância.

No grupo do MTA apenas um espécime exibiu neoformação óssea em proximidade dele, que quando comparado, pelo teste de Dunn com o MBPc os dados não foram significantes, do ponto de vista estatístico. 
Foi também aplicado o Teste $U$ de Mann-Whitney, para verificar se havia diferença estatística significativa entre os 2 grupos experimentais (MTA e MBPc), levando-se em consideração todos os 6 critérios da análise microscópica nos períodos de 7, 15 e 30 dias (Tabelas 41, 42 e 43).

Tabela 41 - Teste U de Mann-Whitney para análise do resultado geral entre os grupos MTA E MBPc no período de 7 dias

\begin{tabular}{|c|c|c|c|c|c|}
\hline Grupos & Média & Mediana & Soma de postos & Posto médio & Amostra \\
\hline MTA & 2,6 & 2,0 & 1351.5 & 37,5 & 36 \\
\hline MBPc & 2,5 & 2,0 & 1276.5 & 37,5 & 36 \\
\hline \multicolumn{6}{|c|}{$U=610.500000$} \\
\hline \multicolumn{6}{|c|}{$Z=0.46647755$} \\
\hline
\end{tabular}

Probabilidade $=0.64087371$

Significante para $p<0,05$

Tabela 42 - Teste U de Mann-Whitney para análise do resultado geral entre os grupos MTA E MBPc no período de 15 dias

\begin{tabular}{c|c|c|c|c|c}
\hline Grupos & Média & Mediana & Soma de postos & Posto médio & Amostra \\
\hline MTA & 2,3 & 2,0 & 1308.0 & 36,3 & 36 \\
\hline MBPc & 2,3 & 2,0 & 1320,0 & 36,7 & 36 \\
\hline
\end{tabular}

$U=642.000000$

$Z=-0.0714973$

Probabilidade $=0.94300195$

Significante para $p<0,05$ 
Tabela 43 - Teste U de Mann-Whitney para análise do resultado geral entre os grupos MTA E MBPc no período de 30 dias

\begin{tabular}{c|c|c|c|c|c}
\hline Grupos & Média & Mediana & Soma de postos & Posto médio & Amostra \\
\hline MTA & 2,2 & 2,0 & 1464,0 & 40,7 & 36 \\
\hline MBPc & 1,9 & 2,0 & 1164,0 & 32,3 & 36 \\
\hline
\end{tabular}

$U=498.000000$

$Z=1.91860501$

Probabilidade $=0.05503434$

Significante para $p<0,05$

De acordo com os resultados acima expostos, pode-se inferir que o MTA e o MBPc não apresentaram diferenças significantes do ponto de vista estatístico, no período de 7, 15 e 30 dias, pois apresentaram resultado geral semelhante.

Entre estes dois grupos, também foi aplicado o teste $U$ de Mann-Whitney para os 6 critérios da análise microscópica individualmente 1 a 1 nos períodos de 7, 15 e 30 dias (Tabela 44).

Tabela 44 - Teste $U$ de Mann-Whitney para análise comparativa do resultado entre o MTA e o MBPc 7, 15 e 30 dias, para cada um dos 6 critérios da análise microscópica

\begin{tabular}{ll|c|c|c}
\hline \multirow{2}{*}{$\begin{array}{c}\text { CRITÉRIOS DE ANÁLISE } \\
\text { MICROSCÓPICA }\end{array}$} & \multicolumn{3}{c}{ VALOR DE $\mathbf{~}$} \\
\cline { 3 - 5 } & $\mathbf{7}$ dias & $\mathbf{1 5}$ dias & $\mathbf{3 0}$ dias \\
\hline 1. & Infiltrado inflamatório & 1.00000000 & 0.65174778 & 1.00000000 \\
\hline 2. & Densidade de fibroblastos jovens & 0.31731052 & 0.59816145 & $\mathbf{0 . 0 3 0 2 7 9 8 5}$ \\
\hline 3. & Densidade angioblástica & 0.65174778 & 0.49840392 & 0.11794163 \\
\hline 4. & Densidade do fibrosamento & 1.00000000 & 1.00000000 & 0.31731052 \\
\hline 5. & Tecido mineralizado & 0.24095468 & 0.05551109 & 0.59055800 \\
\hline 6. & Tecido ósseo & $\mathbf{0 . 0 3 2 5 0 9 4 4}$ & 0.17573433 & 0.44539152 \\
\hline
\end{tabular}

Significante para $p<0,05$ 
De acordo com os resultados acima expostos, pode-se inferir que o grupo do MTA e do MBPc apresentaram diferenças significantes do ponto de vista estatístico, quanto ao critério densidade de fibroblastos jovens no período de 30 dias ( $p=0.03027985)$ e quanto ao critério presença e localização da deposição de tecido ósseo no período de 7 dias ( $p=$ 0.03250944), (Tabela 44).

Apesar do teste de Dunn, quando realizado para comparar os 3 grupos quanto ao critério densidade de fibroblastos jovens no período de 30 dias, não ter demonstrado diferenças do ponto de vista estatístico, a aplicação do teste $U$ de Mann-Whitney, entre os dois grupos experimentais, demonstrou resultados significantes entre os materiais quanto a este critério e tempo.

Quanto ao critério presença e localização da deposição de tecido ósseo, o teste de Mann-Whitney, realizado apenas para os dois grupos teste, demonstrou haver diferenças significantes entre os materiais, no período de 7 dias, assim como o teste de Kruskal-Wallis, realizado para comparação dos 3 grupos.

Vale ressaltar novamente que, nesse período, todos os espécimes do grupo do MBPc apresentaram deposição de tecido ósseo à distância enquanto que no grupo do MTA apenas um espécime exibiu deposição daquele tecido, próximo ao material retrobturador. 
6 DISCUSSÃO 


\section{DISCUSSÃO}

\subsection{DA CONCEPÇÃO DO TRABALHO}

Dentre os materiais mais empregados nos procedimentos de obturação retrógrada destacam-se o amálgama de prata, os derivados do óxido de zinco e eugenol (IRM e Super EBA), o cimento de ionômero de vidro e as resinas compostas. Todos esses materiais apresentam algumas desvantagens. O amálgama, por exemplo, sofre infiltração inicial, corrosão secundária, possibilita a contaminação pelo mercúrio, é sensível à umidade e necessita de um retropreparo retentivo. Já os derivados do óxido de zinco e eugenol são sensíveis à umidade, são irritantes aos tecidos e apresentam solubilidade.

Por outro lado, o MTA, é um material retrobturador que tem demonstrado aderir-se e adaptar-se às paredes dentinárias, prevenindo a infiltração de microorganismos e seus produtos (ADAMO et al. $^{2}$, 1999; TANG; TORABINEJAD; KETTERING ${ }^{134}$, 1997). Demonstrou, também, ser biocompatível e insolúvel aos fluidos teciduais, apresentando, ainda, estabilidade dimensional e radiopacidade adequadas (TORABINEJAD; MacDONALD; PITT FORD ${ }^{145}$, 1995), chegando a ser considerado, segundo seus idealizadores, TORABINEJAD e equipe, como um material retrobturador ideal. A natureza hidrofílica das partículas do pó do MTA confere-Ihe uma característica especial que permite sua utilização, inclusive, na presença de umidade, tal qual ocorre durante os procedimentos clínicos em casos de perfuração e cirurgia parendodôntica, não necessitando, portanto, de campo seco. Nessa situação, a umidade dos tecidos agiria como um ativador da reação química (BERNABÉ; HOLLAND ${ }^{22}$, 2003)

O alvo da presente investigação foi o cimento experimental MBPc, que derivou dos experimentos realizados por MORAES ${ }^{86}$, em 1984. Este material, segundo o autor, é à base de resina epóxica, contendo em sua formulação o hidróxido de cálcio e um componente de resina de 
poliuretana vegetal. Foi idealizado para ser empregado como componente retrobturador para os casos de cirurgia parendodôntica (PAVAN $\left.{ }^{101}, 1999\right)$ e como material selador nos casos de perfurações radiculares ou de furca (SILVA NETO; MORAES ${ }^{126}, 2003$ ).

Objetivou-se avaliar a resposta inflamatória e a neoformação óssea frente a este cimento experimental comparando ao MTA ProRoot em um modelo biológico que possibilitasse a exposição do material, tanto ao tecido conjuntivo, quanto ao tecido ósseo. O alvéolo dentário do rato foi escolhido, justamente, por se tratar de um local de ossificação, onde já se conhece perfeitamente a sucessão de fenômenos biológicos que compreendem seu processo de reparo (OKAMOTO ${ }^{93}$, 1964). Associou-se a este local de implantação, recursos já bem aceitos e padronizados (LANGELAND et al. $^{75}$, 1969; COUNCIL ON DENTAL MATERIAL AND DEVICES $^{34,35}$, 1972 e 1979; STANFORD ${ }^{131}$, 1986; STANLEY ${ }^{132}$, 1992) dos trabalhos realizados em tecido conjuntivo subcutâneo, como 0 acondicionamento dos materiais teste no interior de tubos de polietileno, bem como, parte dos critérios de análise dos resultados. Os tubos permitiram a padronização da quantidade de material inserido e, principalmente, da área que o mesmo ficou exposto ao organismo.

Acredita-se que esta pesquisa supriu totalmente as expectativas para a qual foi idealizada, possibilitando uma análise comparativa entre os dois materiais. 


\subsection{DOS MATERIAIS EMPREGADOS}

Uma série de trabalhos tem demonstrado a excelente capacidade seladora marginal do MTA como material selador de perfurações radiculares (LEE; MONSEF; TORABINEJAD ${ }^{78}$, 1993; CAIEDO et al. ${ }^{28}$, 2000), como selador de perfurações de furca (FORD, et al. ${ }^{48}$, 1995; NAKATA; BAE; BAUMGARTNER ${ }^{91}$, 1998), como material retrobturador em cirurgias parendodônticas (TORABINEJAD et al. ${ }^{137,}{ }^{147}, 1993$ e 1995; BATES; CARNES; DEL RIO ${ }^{9}$, 1996; TANG; TORABINEJAD, KETTERING ${ }^{134}$, 1997; FISCHER; ARENS; MILLER ${ }^{46}$, 1998; WU et al. ${ }^{154}$, 1998; YATSUSHIRO et al. $^{158}$, 1998; AQRABAWI ${ }^{7}$, 2000; MARTELL; CHANDLER $^{82}$, 2000; DALCÓQUIO et al. ${ }^{38}$, 2001; BERNABÉ et al. ${ }^{14}$, 2002), como barreira intracoronária previamente ao clareamento dentário (CUMMINGS; TORABINEJAD ${ }^{36}$, 1995) e como material selador coronário (SNIDER et al. $\left.{ }^{129}, 1999\right)$.

Essa habilidade seladora marginal exibida pelo MTA, provavelmente deve-se à sua natureza hidrofílica e suave expansão quando é manipulado em ambiente úmido (TORABINEJAD; MacDONALD; PITT FORD ${ }^{145}$, 1995), prevenindo a infiltração bacteriana (ADAMO et al. ${ }^{2}, 1999$ ) e a infiltração de endotoxinas bacterianas (TANG; TORABINEJAD; KETTERING ${ }^{134}$, 1997).

Alguns trabalhos também demonstraram a excelente capacidade de selamento marginal proporcionado pelo cimento experimental MBPC.

Quando empregado como material retrobturador, em cirurgias parendodônticas, e avaliado por meio da infiltração de corante, PAVAN $^{101}$, 1999, utilizando um antecessor desse cimento, o MBLc, encontrou excelentes resultados, sendo este material superior, inclusive, ao ionômero de vidro e Super EBA. 
Também empregado como material retrobturador, porém, agora, avaliado quanto ao selamento apical por meio de infiltração bacteriana, SIQUEIRA et al. ${ }^{127}$, 2004, verificaram resultados semelhantes aos observados com o ProRoot MTA.

Quando empregado como material selador de perfurações SILVA NETO; MORAES ${ }^{126}$, 2003, encontraram alta capacidade seladora marginal, e neste caso, superior ao ProRoot MTA.

Dentre algumas propriedades que um material obturador deve possuir, uma delas é que ele apresente algum efeito bactericida ou bacteriostático. Trabalhos de HONG; TORABINEJAD; KETTERING66 (1993), TORABINEJAD et al. ${ }^{139}$ (1995) ESTRELA et al. ${ }^{44}$ (2000), demonstraram que o MTA possui propriedades antimicrobianas em meio de cultura devido ao halo inibitório alcançado pelo material. Os autores sugeriram, que esta propriedade antimicrobiana está relacionada ao elevado $\mathrm{pH}$ e à concentração de íons hidroxila.

BRANDÃO ${ }^{26}$, 1999, avaliou os valores de $\mathrm{pH}$ do cimento MBP, um antecessor do MBPc, para obturação de canal, e encontrou resultados superiores aos cimentos de óxido de zinco e eugenol e Sealer Plus. Apesar dos resultados serem promissores não se pode afirmar que 0 cimento MBPC possua algum efeito bactericida antes que experimentos específicos em culturas bacterianas, possam demonstrar, caso existente, esta propriedade.

Quanto às propriedades biológicas, vários trabalhos têm comprovado que por ser um material biocompatível, o MTA não promove inflamação tecidual significativa. Somado a este fator, este material permite o processo de reparo em diversas situações, inclusive, segundo os autores, induzindo à deposição de tecido dentinário e osteocementário (TORABINEJAD et al. ${ }^{143}$, 1995; PITT FORD et al. ${ }^{108}$, 1996; FORD et al. ${ }^{47}$, 1996; TORABINEJAD et al. ${ }^{142}$, 1997; HOLLAND et al. ${ }^{60}, 1999$; SHABAHANG et al. ${ }^{124}$, 1999; HOLLAND et al. ${ }^{57,58,59}, 2001$ ). 
HOLLAND et al. ${ }^{62}$, 1999, observaram a reação do tecido conjuntivo subcutâneo de rato ao MTA e hidróxido de cálcio verificando que a resposta tecidual foi semelhante para os dois materiais, inclusive, observou-se a presença de um tecido duro irregular permeado por um tecido conjuntivo fibroso. Mediante tais resultados, esses autores aventaram a possibilidade de que o mecanismo de ação do MTA, na indução de deposição de tecido duro, seja similar ao do hidróxido de cálcio, principalmente porque o MTA contém o óxido de cálcio que, quando em contato com a água, se transforma em hidróxido de cálcio.

Por outro lado, o cimento MBPc também possui em sua formulação o hidróxido de cálcio, que é, segundo HOLLAND ${ }^{62}$, o principal componente na característica de colaborar com o processo de reparo. 0 principal questionamento é se o íon cálcio do material é ou não ativo, se ele é ou não liberado e se continua sendo liberado após a presa do material.

Os valores de $\mathrm{pH}$, em torno de 9,7 verificados após 30 dias, por BRANDÃO ${ }^{26}$, quando avaliou o cimento MBP sugerem uma alta concentração de íons hidroxila, o que, de certa forma, também sugere que o íon cálcio foi liberado durante a reação de formação dos íons hidroxila. Reforça-se este aspecto na análise da liberação do íon cálcio também realizada por BRANDÃO ${ }^{26}$. Naquela oportunidade este autor verificou que a liberação de cálcio, principalmente nos períodos de 15 e 30 dias, foram superiores à dos cimento de óxido de zinco e eugenol, Sealer 26 e Sealer Plus.

Apesar destes experimentos sugerirem uma ação do hidróxido de cálcio contido neste material, estudos de caráter biológico, como os realizados por HOLLAND e BERNABÉ com o MTA, em tecido subcutâneo de ratos (HOLLAND et al. ${ }^{61,62,63}, 1999,2001$ e 2002), em obturações retrógradas (BERNABÉ et al. ${ }^{15}$ 16, 17, 18, 19, 2002 e 2004), perfurações radiculares (HOLLAND et al. ${ }^{59}$, 2001) e pulpotomias em dentes de cães (HOLLAND et al. $\left.{ }^{58}, 2001\right)$, também devem ser realizados com 0 
cimento experimental MBPc no intuito de comprovarem definitivamente sua efetiva ação nos tecidos. 


\subsection{DA METODOLOGIA EMPREGADA}

Quanto aos métodos de avaliação da biocompatibilidade de materiais retrobturadores o estudo tem sido realizado em dentes de animais (ROWE ${ }^{110}$, 1967; PITT FORD ${ }^{106}$, 1983) implante em tecido subcutâneo de ratos (TORNEC ${ }^{148,149}, 1966$ e 1967; PHILLIPS ${ }^{104}$, 1967; MORSE et al. ${ }^{90}$, 1981; OLSSON et al. ${ }^{98}$, 1981; ORSTAVIC; MIJÖR ${ }^{99}$, 1988; MOLLOY et al. ${ }^{85}$, 1992; ECONOMIADES et al. ${ }^{42}$, 1995), alvéolo dentário (OKAMOTO ${ }^{93}$, 1964; SANCHES et al. ${ }^{119}$, 1982; DeGROOG et al. ${ }^{41}$, 1995) e, ainda, em cultura de células (LANGELAND; OLSSON; PASCON ${ }^{76}$, 1981; SAFAVI et al. ${ }^{116}$, 1989).

O implante em alvéolo dentário merece destaque por apresentar peculiaridades próprias em suas diferentes etapas de maturação (OKAMOTO ${ }^{93}$, 1964). Por ser uma cavidade óssea revestida por ligamento periodontal, desperta particular interesse, pois a organização do coágulo e a presença de restos do ligamento periodontal são fundamentais para 0 processo de reparo em feridas de extração dentária (DeGROOG, et al. ${ }^{41}$, 1995; NARY FILHO; OKAMOTO ${ }^{92}$, 1994; LIN; MCCULLOCH; $\left.\mathrm{CHO}^{80}, 1994\right)$. É, portanto, ótimo local para estudos comparativos entre materiais implantados, pela sucessão de fenômenos biológicos que nele transcorre e pela possibilidade de neoformação conjuntiva ou mineralizada, em contato direto com o material (CARVALHO; OKAMOTO ${ }^{29}$, 1978), o que determina, desta forma, uma região de reparo específica e que poderia simular um ambiente de um tratamento endodôntico ou parendodôntico.

O implante de materiais odontológicos no interior de alvéolos dentários de ratos sejam eles, com finalidade hemostática (SANTOS-PINTO et al. $^{121}$, 1969, OKAMOTO et al. $^{94}$, 1974, SAAD NETO; CARVALHO; OKAMOTO ${ }^{113}$, 1975, SANCHES et al. ${ }^{118}$, 1976, OKAMOTO; SOLER; BARROSO $^{97}$, 1983, SAAD NETO; CALLESTINI; OKAMOTO ${ }^{112}$, 1987), para o tratamento de infecções alveolares (SASAKI; OKAMOTO ${ }^{122}$, 1968, CARVALHO; OKAMOTO ${ }^{29}$, 1978, CURY et al. ${ }^{37}$, 1983) ou testes de biocompatibilidade de implantes aloplásticos (CASTRO et al. ${ }^{33}$, 1970, 
SANCHES; OKAMOTO; CARVALHO ${ }^{120}$, 1972, OKAMOTO et al. ${ }^{94}, 1974$, VICTOR et al. ${ }^{153}$, 1975, SAAD NETO; CARVALHO; OKAMOTO ${ }^{114}$, 1979/80, SANCHES et al. ${ }^{119}$, 1982) caracterizaram-se pelo preenchimento total ou parcial do alvéolo, implicando num traumatismo mecânico sobre suas paredes, independente do potencial irritante do material. CARVALHO; OKAMOTO $^{29}$, 1978, e SAAD NETO; CALLESTINI; OKAMOTO ${ }^{112}$, 1987, relataram que o trauma sobre as paredes alveolares é induzido pela compressão do tecido ósseo o que gera a reabsorção. Este agravante, associado ao trauma cirúrgico, dificulta a organização do coágulo no sentido da formação do tecido de granulação atrasando, de forma geral, os eventos reparacionais.

O método para a avaliação de biocompatibilidade em feridas de extração dentária consiste no implante dos materiais teste diretamente no interior do alvéolo dentário após extração. Entretanto, especificamente com relação aos materiais retrobturadores, uma série de outras variáveis, além do modelo biológico e local de implantação, deve ser considerada. A quantidade do material a ser implantado, a relação da mistura (proporção), o mecanismo de contato do material com o sistema biológico, a temperatura ambiente e o tempo de trabalho são de difícil padronização. Na tentativa de se contornar tais problemas, propôs-se, no presente trabalho, incorporar a metodologia que se utiliza do implante de tubos de polietileno, que são largamente empregados e aceito como protocolo para testes de biocompatibilidade (COUNCIL ON DENTAL MATERIALS AND DEVICES ${ }^{34}$, 35,1972 e 1979) em tecido subcutâneo, porém, agora, preenchidos com os materiais a serem avaliados e implantados em alvéolos dentários de ratos após extração.

Estes tubos, utilizados como matriz para os materiais retrobturadores, evitaria o trauma mecânico exercido pelos materiais caso estes fossem implantados sozinhos, sob pressão. Outro aspecto interessante e muito importante é que, com o emprego dos tubos de polietileno, foi possível a padronização da quantidade de material implantado 
por espécime e, principalmente, da área em que o mesmo ficou em contato com o organismo.

Utilizando esse meio para inserção do material e o alvéolo dentário como excelente área de estudo de reparo ósseo, acredita-se ser possível uma avaliação mais apropriada do comportamento biológico dos materiais retrobturadores. Em sendo assim, a presente investigação também objetivou avaliar esta metodologia com materiais endodônticos, visando ampliar as opções de testes para esses materiais.

Vários foram os estudos que comprovaram a biocompatibilidade dos tubos de polietileno empregados neste experimento. O primeiro deles foi com TORNECK ${ }^{148}$, em 1966, quando estudou a reação do tecido conjuntivo subcutâneo de ratos frente a implantes com esse tipo de tubo. O autor observou discreta reação inflamatória induzida por este material, com presença de cápsula fibrosa não infiltrada, de pequena espessura, apresentando fibras colágenas e células dispostas paralelamente à sua superfície, o que caracterizou uma excelente tolerância ao material por parte do organismo. O autor relatou que, mesmo nos tubos de menor diâmetro e comprimento $(4 \times 0,58 \mathrm{~mm})$, houve crescimento de tecido conjuntivo para dentro do tubo, o que mais tarde, justamente por esse crescimento infiltrativo, estimulou as pesquisas desenvolvidas por HOLLAND ${ }^{64}$ et al., em 1973, CARVALHO ${ }^{32}$ et al., em 1976, BERNABÉ ${ }^{11}$, em 1977, AGUIAR; SANTOS PINTO; OKAMOTO4 , em 1981, e OLSSON ${ }^{98}$ et al., em 1981.

Até 1972, não havia uma metodologia padronizada para testar biologicamente os materiais dentários, quando, então, o Council on Dental Material and Devices ${ }^{34}$, divisão do controle de materiais odontológicos da ADA (American Dental Association), publicou um guia para testes de novos produtos, onde relatou a aplicação de técnicas padronizadas, na avaliação da resposta tecidual de materiais odontológicos. Um dos testes de toxicidade dos materiais, recomendado, foi o implante em tecido subcutâneo. 
HOLLAND et al. $^{64}$, em 1973, empregaram os tubos de polietileno no estudo da resposta do tecido conjuntivo subcutâneo de ratos, frente a implantes de alguns materiais obturadores, utilizando como controle a guta-percha. CARVALHO; OKAMOTO; SAAD NETO ${ }^{32}$, em 1976, analisaram o comportamento biológico de anestésicos locais, BERNABÉ ${ }^{11}$, em 1977, AGUIAR; SANTOS PINTO; OKAMOTO4, em 1981, avaliaram a resposta tecidual frente ao emprego de materiais utilizados em obturações retrógradas de canais radiculares, obtendo excelentes resultados com esta metodologia, principalmente devido às características do material de que era constituído o tubo.

Em 1980, STANFORD ${ }^{130}$, publicou um artigo relatando práticas padronizadas para testes biológicos de materiais dentários. Novamente os testes em tecido subcutâneo de ratos foram citados.

A FDI e a ISO preconizam a utilização da parede do tubo de polietileno para servir como grupo controle (STANFORD ${ }^{130}$, 1980; INTERNATIONAL ORGANIZATION FOR STANDARDIZATION ${ }^{67}$, 1997). Na presente investigação utilizou-se como grupo controle os tubos vazios com o propósito de se observar e comparar o reparo alveolar com aquele observado nos grupos, cuja reação inflamatória, em resposta ao material, poderia ser observada. Quando aplicável, o padrão ISO simplifica a metodologia e facilita o caminho do pesquisador, no entanto, a metodologia proposta não encontra sustentação na literatura para que se utilize a parede do tubo como controle, principalmente por não se saber o que poderia ocorrer se caso os tubos fossem implantados vazios. De antemão, pode-se dizer que o implante do tubo vazio atrasou o reparo geral do alvéolo dentário, quando comparado a outros trabalhos (ASTRAND; CARLSSON ${ }^{8}$, 1969; OKAMOTO; RUSSO ${ }^{98}$, 1973; CARVALHO; OKAMOTO ${ }^{30}$, 1985; OKAMOTO et al. $^{95}$, 1994; LAMANO CARVALHO; BOMBONATO; BRENTEGANI $\left.^{73}, 1997\right)$ e, portanto, fica claro a necessidade de se empregar nesse modelo biológico um grupo controle onde os tubos de polietileno permanecessem vazios, com o intuito de se estabelecer parâmetros para 
uma análise comparativa entre materiais endodônticos. Desse modo, acredita-se que a dificuldade em seguir os padrões FDI / ISO para a maioria dos pesquisadores reside-se, principalmente, no tipo de material testado e, neste caso, na metodologia empregada.

Outro fator relevante quanto à utilização da parede do tubo como controle é que, não se sabe se a superfície do tubo onde se localiza a luz do mesmo é igual à parede lateral do tubo, pois, após o corte que padronizou o comprimento dos tubos empregados, poderia ocorrer exposições de porosidades do material que o constitui e influir de maneira significativa no processo de reparo, mascarando, desta forma, os resultados advindos do potencial irritante dos materiais.

A maioria dos trabalhos realizados com materiais endodônticos coloca como parâmetro de comparação a guta-percha. Entretanto, por se tratar de um primeiro trabalho empregando-se tal metodologia em incisivo central superior, julgou-se oportuno empregar um grupo controle onde apenas a influência do tubo fosse levada em consideração. Acreditou-se que, quando da colocação de um grupo controle com a guta-percha, resultados relativos ao potencial irritativo do material poderia dificultar a análise comparativa proposta, entre os materiais. Os resultados encontrados evidenciaram a necessidade de se empregar um grupo controle constituído de tubos de polietileno vazios e, também não se descarta a idéia de, para futuros trabalhos, empregar-se, também, outro grupo controle, porém, agora, constituído de tubos de polietileno preenchidos com guta-percha, formando, desta forma, um grupo controle negativo (vazio) e um grupo controle positivo (guta-percha).

Ainda com relação aos critérios FDI / ISO para a avaliação dos resultados de testes em subcutâneo, o material é aceitável quando provoca, no tecido adjacente, uma reação inflamatória leve ou moderada. Os dados evidenciados no presente trabalho, corroboram, de certa forma, com os critérios FDI / ISO, pois o potencial irritante verificado com o MTA se assemelha aos achados de HOLLAND et al. ${ }^{62}$, 1999, em tecido subcutâneo 
de ratos. Por conseguinte, acredita-se que para esse modelo biológico uma reação inflamatória moderada observada em períodos menores como os de 7 e 15 dias poderia ser encarada como satisfatória e, em períodos maiores como os de 30 dias esta reação poderia apresentar-se discreta ou ainda, como em alguns espécimes, ausente. Apesar de não ter sido adotado períodos que ultrapassassem o de 30 dias, como no trabalho de DEGROOD et al. $^{41}$, 1995, acredita-se que, em períodos maiores, o emprego dos materiais, aqui propostos, proporcionaria um reparo isento de inflamação, pois, conforme já mencionado, o processo de reparo, em alguns espécimes aos 30 dias, já assim o apresentavam.

Com relação ao processamento laboratorial das peças obtidas, um aspecto importante e interessante observado é que, foi possível realizar o corte, em micrótomo convencional, das peças obtidas sem que se removesse os tubos de polietileno, o que, normalmente, não ocorre quando da realização do implante em tecido subcutâneo, justamente pelo material que o constitui. Acredita-se que, esta manobra foi possível pois as paredes laterais do alvéolo, mesmo após o processo de desmineralização, provavelmente, ofereceram ancoragem suficiente para permitir o corte do tubo sem que se necessitasse sua remoção.

Comparando a resposta obtida no presente trabalho, àquelas obtidas em trabalhos realizados em tecido subcutâneo de ratos, que removem o tubo após inclusão em parafina, evidencia-se que a não remoção do tubo parece ser coadjuvante na tentativa de não se mascarar a resposta dos tecidos frente aos materiais, pois a remoção do tubo poderia levar consigo, além do material contido, parte da resposta tecidual, principalmente, aquela localizada mais próximo ao material que, de certa forma, é a mais importante e relevante na análise microscópica.

Ainda, com relação aos testes realizados em tecido subcutâneo de ratos, pode-se mencionar que o implante, neste local, normalmente migra e, esta ocorrência pode ser verificada no momento da retirada dos tubos para análise. O implante em alvéolo dentário supera este 
inconveniente, pois o alvéolo oferece sustentação e contenção para 0 implante não possibilitando uma grande movimentação, o que, de certa forma, pode possibilitar a obtenção de resultados mais confiáveis. Outro fator a ser considerado e comparado aos resultados obtidos em tecido subcutâneo é que o ambiente odontogênico proporcionado pelo alvéolo, por analogia, representa melhor as condições em que são empregados os materiais endodônticos testados, quando do seu emprego rotineiro em humanos.

No presente trabalho, para a determinação do tipo de tubo de polietileno, principalmente no que se refere a detalhes como o comprimento e o diâmetro do tubo que seria mais adequado a este procedimento, foi previamente realizada a extração de 1 incisivo superior de um animal de idade, tamanho e peso semelhantes aos que foram utilizados, posteriormente, neste experimento. De posse do dente foram realizados cortes em seu sentido transversal e anotadas as medidas correspondentes ao diâmetro e curvatura do elemento dentário. O maior diâmetro das secções do dente extraído ficou em torno de $1,8 \mathrm{~mm}$, determinando que o tubo a ser escolhido deveria ser de menor calibre. Em sendo assim, foram utilizados 48 tubos de polietileno com 1,0mm de diâmetro interno, 1,6mm de diâmetro externo e 3,0mm de comprimento, os quais foram introduzidos no terço médio do alvéolo com o auxílio de um instrumental que respeitou a curvatura alveolar. Este procedimento preliminar objetivou superar os problemas inerentes ao traumatismo ocasionado pelos tubos de polietileno no momento de sua implantação, verificados no trabalho piloto. Neste caso específico, os tubos empregados foram de 1,8mm de diâmetro externo e, após análise microscópica verificou-se que houve uma compressão nas paredes laterais do alvéolo, bem como um esmagamento do ligamento periodontal em sentido apical, decorrente do diâmetro do tubo empregado. Diante dessas observações, julgou-se importante verificar o diâmetro médio dos alvéolos dos ratos utilizados nesse experimento para novamente não cometer erros metodológicos que pudessem comprometer os resultados encontrados. 
Quanto à análise microscópica descritiva adotada no presente trabalho, a mesma, foi baseada nos critérios observados em trabalhos de OKAMOTO e CARVALHO (OKAMOTO et al. ${ }^{95}$, 1994; CARVALHO; OKAMOTO $\left.{ }^{29}, 1978\right)$, onde, de forma geral, descreveram o processo de reparo em seus diferentes estádios e nos diferentes terços alveolares. Algumas modificações foram adotadas na descrição dos fenômenos observados microscopicamente, em função do propósito do trabalho. Evidenciou-se, principalmente, a reação tecidual proveniente dos materiais retrobturadores, no contexto do reparo alveolar.

A análise quantitativa adotada, realizada por meio da atribuição de escores, graduando as magnitudes dos fenômenos microscópicos observados separadamente, foi baseada nos critérios descritos por BERNABÉ ${ }^{10,12}, 1981$ e 1994, e VALERA ${ }^{152}$, 1995, porém com algumas modificações, em função do modelo biológico proposto neste trabalho e após algumas observações microscópicas. O crescimento do tecido ósseo próximo aos materiais e a presença de calcificações distróficas, classificadas, nos critérios de análise, como presença de tecido mineralizado, foram achados que revelaram a necessidade de se considerar. tais constatações, em critérios de análise microscópica, individualizados. 


\subsection{DOS RESULTADOS OBTIDOS}

Pode-se observar o desenvolvimento normal do reparo alveolar junto às paredes do tubo, evidenciado pela interação celular entre fibroblastos, macrófagos e células gigantes multinucleadas inflamatórias, o que, de certa forma, indicam a boa compatibilidade biológica dos tubos de polietileno com o tecido alveolar, corroborando com os trabalhos de TORNECK ${ }^{148}, 1966$, HOLLAND ${ }^{64}$ et al., em 1973, CARVALHO; OKAMOTO; SAAD NETO ${ }^{15}$, em 1976, BERNABÉ ${ }^{11}$, em 1977, AGUIAR; SANTOS PINTO; OKAMOTO ${ }^{4}$, em 1981 e OLSSON ${ }^{98}$ et al., em 1981.

O grupo controle, representado por aqueles espécimes nos quais o tubo que foi inserido no alvéolo dentário estava selado apenas em uma extremidade e com a outra aberta e voltada para o fundo alveolar, apresentou um crescimento de tecido conjuntivo em seu interior em todos os tempos pós-operatórios, semelhante ao crescimento infiltrativo verificado por TORNECK ${ }^{148}$, em 1966.

Nas porções laterais do tubo, observou-se que houve um desenvolvimento normal do processo de reparo, principalmente no nível do terço médio das paredes do alvéolo. Este dado, aparentemente, indicou sucesso em se eliminar o trauma mecânico exercido sobre as paredes alveolares na introdução do tubo. Nos grupos experimentais, logicamente, não foi observado crescimento infiltrativo do tecido na luz do tubo, justamente pela presença física dos materiais contidos.

Apesar dos bons resultados observados em todos os grupos, dois espécimes exibiram quadro compatível com alveolite parecendo guardar relações com o trauma em uma das paredes alveolares, conforme já discutido. A coloração de Brown e Brenn, nestes dois espécimes, comprovou a presença de bactérias, o que também levanta suspeita quanto a uma possível contaminação do alvéolo, pelo tubo implantado, no momento cirúrgico. Apesar de nenhum dos 48 tubos terem sido expulsos do alvéolo, CARVALHO; OKAMOTO ${ }^{31}$, em 1987, salientaram que os implantes 
realizados em alvéolos que exibem quadros compatíveis com infecção alveolar tendem a ser eliminados pelo organismo. Como o período experimental não ultrapassou os 30 dias, acredita-se que, a expulsão dos tubos nos espécimes infectados seria apenas uma questão de tempo.

SAAD NETO et al. ${ }^{112}$, em 1987, relataram que a pressão hidrostática exercida no fundo alveolar, originada pela hemorragia decorrente da extração do elemento dentário favorece o deslocamento do material quando implantado no alvéolo ou até mesmo sua expulsão. Ressaltaram, ainda, que este deslocamento, em sentido cervical, pode resultar em um contato com o meio bucal, o que propiciaria a ocorrência de infecções.

Notou-se, neste experimento, que alguns dos espécimes, mesmo quando colocados ao nível do terço médio do alvéolo, após a morte dos animais, demonstravam algum deslocamento sempre em sentido cervical, o que corrobora com os relatos de SAAD NETO et al. ${ }^{112}, 1987$.

Destaca-se ainda, com respeito ao emprego dos tubos de polietileno que, no processo geral de reparo alveolar, houve um atraso em sua cronologia de maneira uniforme entre os grupos experimentais, quando comparado aos trabalhos de ASTRAND; CARLSSON ${ }^{8}$, 1969; OKAMOTO; RUSSO $^{96}$, 1973; CARVALHO; OKAMOTO ${ }^{30}$, 1985; OKAMOTO et al. ${ }^{95}$, 1994; LAMANO CARVALHO; BOMBONATO; BRENTEGANI ${ }^{73}, 1997$ que avaliaram a cronologia do processo de reparo em alvéolos sem os tubos. Pode-se verificar um atraso na neoformação óssea nos períodos iniciais diferindo-se apenas próximo à região que o material retrobturador permaneceu exposto ao tecido alveolar. Após 30 dias verificou-se que a formação trabecular em muitas regiões ainda era moderada e, se comparada a situações normais, ou seja, sem a presença do tubo, o alvéolo já deveria estar reparado. Devese considerar que este atraso na cronologia de reparo já era de se esperar, como discutido anteriormente, porém destaca-se novamente a característica da resposta biológica nos diferentes terços do alvéolo, principalmente no nível médio, onde é possível afirmar que a influência do tubo deve ter sido 
mínima. Entretanto, este aspecto referente ao atraso na reparação alveolar não foi um fator levado em consideração, neste experimento, e recomendase, desde já, a necessidade de períodos mais longos do que os aqui propostos e, talvez como os empregados por DEGROOD, et al. ${ }^{41}$, 1995, de até 90 dias, na busca de se evidenciar um reparo ósseo completo diante dos materiais testados.

LAMANO CARVALHO; BOMBONATO; BRENTEGANI ${ }^{73}$, em 1997, realizaram um trabalho com avaliação histométrica e relataram que o processo de reparo normal de alvéolos dentários de ratos, se estendeu além da terceira semana, o que discorda dos trabalhos de ASTRAND; CARLSSON $^{8}$, 1969; OKAMOTO; RUSSO ${ }^{96}$, 1973; CARVALHO; OKAMOTO $^{30}$, 1985. Entretanto, as diferenças encontradas, por LAMANO CARVALHO; BOMBONATO; BRENTEGANI ${ }^{73}$, 1997, foram significantes quando da comparação do terço cervical dos alvéolos.

No presente trabalho os tubos foram implantados no nível do terço médio do alvéolo e, portanto, nessa região, os trabalhos são categóricos em relatar que no período de 30 dias os alvéolos deveriam apresentar-se completamente reparados. Este fato sugere que o atraso na reparação global do alvéolo deve ter sido em função da presença física do tubo de polietileno, e que as áreas de contato do tecido conjuntivo com os materiais teste são representativas de uma reação tecidual aos componentes do material retrobturador.

Especificamente, em relação à reação tecidual ocorrida no grupo do MTA, verificou-se uma resposta inflamatória semelhante àquela descrita por HOLLAND et al. ${ }^{62}$, 1999, em trabalho realizado em tecido subcutâneo de ratos. Observou-se uma faixa superficial de espessura irregular com necrose por coagulação e, subjacente a ela um discreto infiltrado inflamatório, aos 7 dias (Fig. 24 E). Nos períodos de 15 e 30 dias o tecido conjuntivo tornou-se mais organizado, preservando apenas macrófagos e células multinucleadas inflamatórias, em contato com 0 material e o tubo. Observou-se, ainda, abaixo das áreas de necrose por 
coagulação na interface entre o tecido conjuntivo e o material, a presença de áreas basofílicas no período de 15 dias (Fig. 27 E) que, se assemelham àquelas observadas por HOLLAND et al. ${ }^{62}$, 1999. Aos 30 dias, alguns casos, evidenciavam a presença de tecido mineralizado em contato com o material (Fig. 30 E). Este aspecto sugere que a faixa de necrose superficial, provavelmente, serviu, ao longo do tempo, como matriz de mineralização.

Esses achados são sustentados com o trabalho de PINHEIRO; ROLDI; CONSOLARO ${ }^{105}$; de 2002, que avaliaram a citotoxicidade do implante do MTA em tecido conjuntivo subcutâneo de ratos, acondicionado em discos de dentina. As presenças de cápsula fibrosa, de discreto infiltrado inflamatório e de calcificações distróficas, foram observadas aos 21 dias.

Recentemente YALTIRIK, et al. ${ }^{157}$, também publicaram um trabalho, onde foi empregado o MTA em tecido conjuntivo subcutâneo de ratos, porém acondicionado em tubos de polietileno. Os autores relataram a presença de cápsula fibrosa e discreto infiltrado inflamatório aos 30 dias. Também afirmaram terem observado, por meio da coloração de Von Kossa, a presença de calcificações distróficas, próximo ao material. Entretanto, quando se compara esses relatos com os achados de HOLLAND et al. ${ }^{62}$, 1999, e de PINHEIRO; ROLDI; CONSOLARO ${ }^{105}$, 2002, levanta-se questionamentos. As figuras apresentadas por YALTIRIK, et al. ${ }^{157}$, 2004, caracterizam-se por apresentar um grande número de macrófagos circunscrevendo parte do material que foi extravasado ou tentando fagocitálo, além de fibroblastos organizando-se ao redor desse aglomerado e não por apresentar calcificação distrófica.

Evidenciou-se, por meio da coloração de H.E.(HOLLAND et al. $^{62}$, 1999; PINHEIRO; ROLDI; CONSOLARO ${ }^{105}$, 2002) ou por meio da coloração de Von Kossa (HOLLAND et al. ${ }^{62,63,} 1999$ e 2001) e nos resultados aqui apresentados, que o MTA é um material que pode promover um ambiente tal que, colaboraria com o formação de calcificações distróficas, em contato como o material, no entanto, questiona-se o trabalho 
de YALTIRIK, et al. ${ }^{157}, 2004$, pelas imagens apresentadas e suas referentes legendas.

HOLLAND et al. ${ }^{62}, 1999$, relataram que o óxido de cálcio presente no MTA, quando em contato com a água, seria convertido em hidróxido de cálcio que, em contato com os fluidos teciduais, se dissociaria

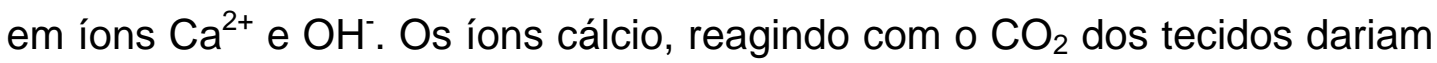
origem às granulações de calcita, gerando o acúmulo de fibronectina, que por sua vez propiciaria a migração, adesão e diferenciação celular, com conseqüente formação de tecido duro. Essa proteína, a fibronectina, é produzida por fibroblastos, macrófagos e células endoteliais e pertence a um grupo de moléculas responsáveis pela migração, adesão e diferenciação celular de células pulpares e periodontais, que sintetizam e depositam colágeno tipo I, dando origem à matriz extra-celular (TROWBRIDGE; EMLING ${ }^{150}$, 1996). Ela também poderia influenciar na diferenciação de células pulpares em odontoblastos, ou células do periodonto, em cementoblastos, responsáveis principais pela deposição de minerais (BERNABÉ; HOLLAND ${ }^{22}$, 2003). A fase líquida saturada de íons hidroxila pode ser responsável pela ligeira camada de necrose superficial, situada entre a ponte de tecido mineralizado e o material, também observada na presente investigação (Fig. $30 \mathrm{C}$ ). Acredita-se que mais uma vez o MTA deu condições para que o reparo ocorresse.

Com relação à extremidade onde o MBPc foi inserido, verificou-se uma resposta inflamatória com algumas semelhanças àquelas observadas com o MTA. O infiltrado inflamatório observado aos 7 dias, caracterizou-se por apresentar macrófagos e eventuais neutrófilos de permeio aos fibroblastos jovens e aos vasos neoformados. $\mathrm{Na}$ interface do material com o tecido conjuntivo notou-se uma faixa de hemorragia e fragmentação nuclear. No interior desta faixa observaram-se restos celulares de permeio a um material hialino, provavelmente, fruto da interação entre o componente resinoso do material e o tecido (Fig. 25 F). 
A molécula de Bis-GMA, principal componente do MBPc, é facilmente solubilizada (HANKS et al. ${ }^{53}$, 1991; RATHBUN et al. ${ }^{109}$, 1991), o que, segundo $\operatorname{LANZA}^{77}$, 1997, que observou a interação de componente adesivo sobre a polpa, poderia ter provocado a interação dessa molécula com os tecidos.

Em alguns espécimes constatou-se o contato direto entre fibroblastos e eventuais macrófagos e células gigantes multinucleadas inflamatórias com a faixa hialina, por vezes, até com o próprio material. Esta faixa apresentou-se mais ampla e espessa do que a faixa de necrose por coagulação superficial verificada com o MTA. Observou-se, ainda, nos períodos de 15 e 30 dias, que o tecido em contato com o material também apresentou áreas basofílicas semelhantes às verificadas com o MTA, porém com menor grau de organização (Fig. 28 F).

Apesar da faixa de necrose e das zonas basofílicas serem menos organizadas quando da presença do MBPc, estas, se assemelharam às observadas com o MTA. Devido a esta semelhança, observada microscopicamente na reação tecidual provocada por ambos materiais em estudo, acredita-se que, o mecanismo de ação do MBPc guarda algumas semelhanças com aquele verificado com o MTA e descrito por HOLLAND et al. $^{62}$, em 1999.

O trabalho realizado por DEGROOD et al. ${ }^{41}$, em 1995, colaborou em parte com análise dos resultados, principalmente por apresentar uma metodologia semelhante à aqui proposta, porém realizada em alvéolos de incisivos inferiores de ratos. Estabeleceu-se uma análise comparativa entre esse trabalho e os resultados aqui evidenciados, o que possibilitou um maior esclarecimento quanto ao modelo biológico empregado, colaborando com a avaliação dos parâmetros estabelecidos neste experimento.

DEGROOD et al. ${ }^{41}$, 1995, observaram, no grupo controle aos 90 dias a presença de tecido ósseo no interior do tubo de polietileno 
(Fig. 38 B,D) e, os resultados, aqui apresentados, revelaram a presença de tecido ósseo logo após a abertura do tubo nesse grupo, porém aos 30 dias (Fig. 38 A,C). No grupo que DEGROOD et al. ${ }^{41}$, 1995, empregaram o amálgama, relatou-se a presença de discreto infiltrado inflamatório em três espécimes e moderado em dois, após 14 dias (Fig. 38 F,H), enquanto que, no grupo do Ketac-Fill foi observado, aos 42 dias, a presença de discreto infiltrado inflamatório em seis dos sete espécimes avaliados e o outro, segundo eles, apresentava-se isento de inflamação (Fig. 38 J,M).

Em contraste com os resultados aqui encontrados, notou-se que, aos 30 dias, tanto no grupo do MTA, quanto no do MBPc, 4 espécimes com discreto infiltrado inflamatório e em dois espécimes o aspecto microscópico evidenciou ausência de inflamação (Tabela 17). Este fato sugere que, em períodos mais longos como os empregados por DEGROOD et al. $^{41}$, 1995, o MTA e o MBPc poderiam proporcionar melhores resultados, quanto ao infiltrado inflamatório, se comparados aos observados com 0 amálgama e o Ketac-Fill.

Outro aspecto importante verificado na tabela 2 do trabalho de DEGROOD et al. $^{41}$, 1995, foi quanto à formação de tecido ósseo, observada nos grupos do amálgama e do Ketac-Fill. A partir desta tabela, estabeleceu-se uma comparação da neoformação óssea entre esses grupos e os grupos MTA e MBPc da presente pesquisa.

O amálgama não apresentou, aos 14 dias, formação de tecido ósseo, em nenhum dos cinco espécimes avaliados, enquanto que, o Ketac-Fill apresentou formação desse tecido em dois dos seis espécimes avaliados, porém, não se especificou o local dessa neoformação. Em contraste verificou-se, com o MTA, a presença de tecido ósseo, aos 15 dias, em metade dos espécimes, sendo que, em um deles, a neoformação óssea encontrava-se próxima ao material (Tabela 31). No grupo do MBPc a resposta, quanto à neoformação óssea, foi ainda melhor, demonstrando presença de tecido ósseo em cinco dos seis espécimes e, em três deles, localizado próximo ao material (Tabela 31). 
Aos 42 dias o grupo do Ketac-Fill apresentou quatro dos sete espécimes com neoformação óssea, enquanto que o amálgama, nesse período, apresentou este tecido em apenas três dos seis espécimes. Em períodos menores, como os de 30 dias, aqui verificados, observou-se, mais uma vez, melhores resultados, pois, com o MTA já havia formação de tecido ósseo em todos os espécimes e com o MBPc em quatro dos seis espécimes, nesse período.

Um aspecto não observado por DEGROOD et al. ${ }^{41}, 1995$, e evidenciado nesta pesquisa, foi a presença de áreas basofílicas e de tecido mineralizado em contato com os materiais (Fig. 25, 27, 28, 30, 31).

Depreende-se dos resultados aqui expostos e discutidos que, apesar dos excelentes resultados verificados com o MTA e, principalmente, com o $\mathrm{MBPc}$, há de se realizar novos experimentos com esses materiais, em especial com o cimento experimental, em outras regiões e situações, na busca de maiores informações referentes ao seu comportamento biológico. 


\section{DISCUSSÃO DOS RESULTADOS OBTIDOS E O TRABALHO DE DEGROOD et al. ${ }^{41}, 1995$}

Figura 38 A - Grupo Controle, 15 dias.

Figura 38 B - Observa-se a presença de tecido ósseo no interior do tubo de polietileno, aos 90 dias (DEGROOD et al. $\left.{ }^{41}, 1995\right)$.

Figura 38 C - Aspecto da neoformação óssea localizada próxima à luz do tubo. Subjacente observa-se, junto ao tecido conjuntivo, baixa celularidade e grande quantidade de matriz colagênica.

Figura 38 D - Em maior aumento, nota-se o aspecto do tecido ósseo invaginado (DEGROOD et al. $\left.{ }^{41}, 1995\right)$.

Figura 38 E - Grupo ProRoot MTA, 30 dias.

Figura 38 F - - Aspecto microscópico panorâmico do grupo do amálgama aos 14 dias (DEGROOD et al. ${ }^{41}$, 1995).

Figura 38 G - Nota-se a presença de tecido mineralizado interposto entre o material e o tecido conjuntivo.

Figura 38 H - Destaca-se, no grupo do amálgama, segundo DEGROOD et al. ${ }^{41}$ (1995), a presença de discreto infiltrado inflamatório.

Figura 38 I - Grupo MBPc, 30 dias.

Figura 38 J - Aspecto microscópico panorâmico do grupo do Ketac-Fill, aos 42 dias (DEGROOD et al. ${ }^{41}$, 1995).

Figura 38 L - Destaca-se, o contato direto entre o material e o tecido ósseo neoformado e tecido conjuntivo isento de inflamação.

Figura 38 M - Nota-se, no grupo do Ketac-Fill aos 42 dias, segundo DEGROOD et al. ${ }^{41}$,presença de discreto infiltrado inflamatório. 


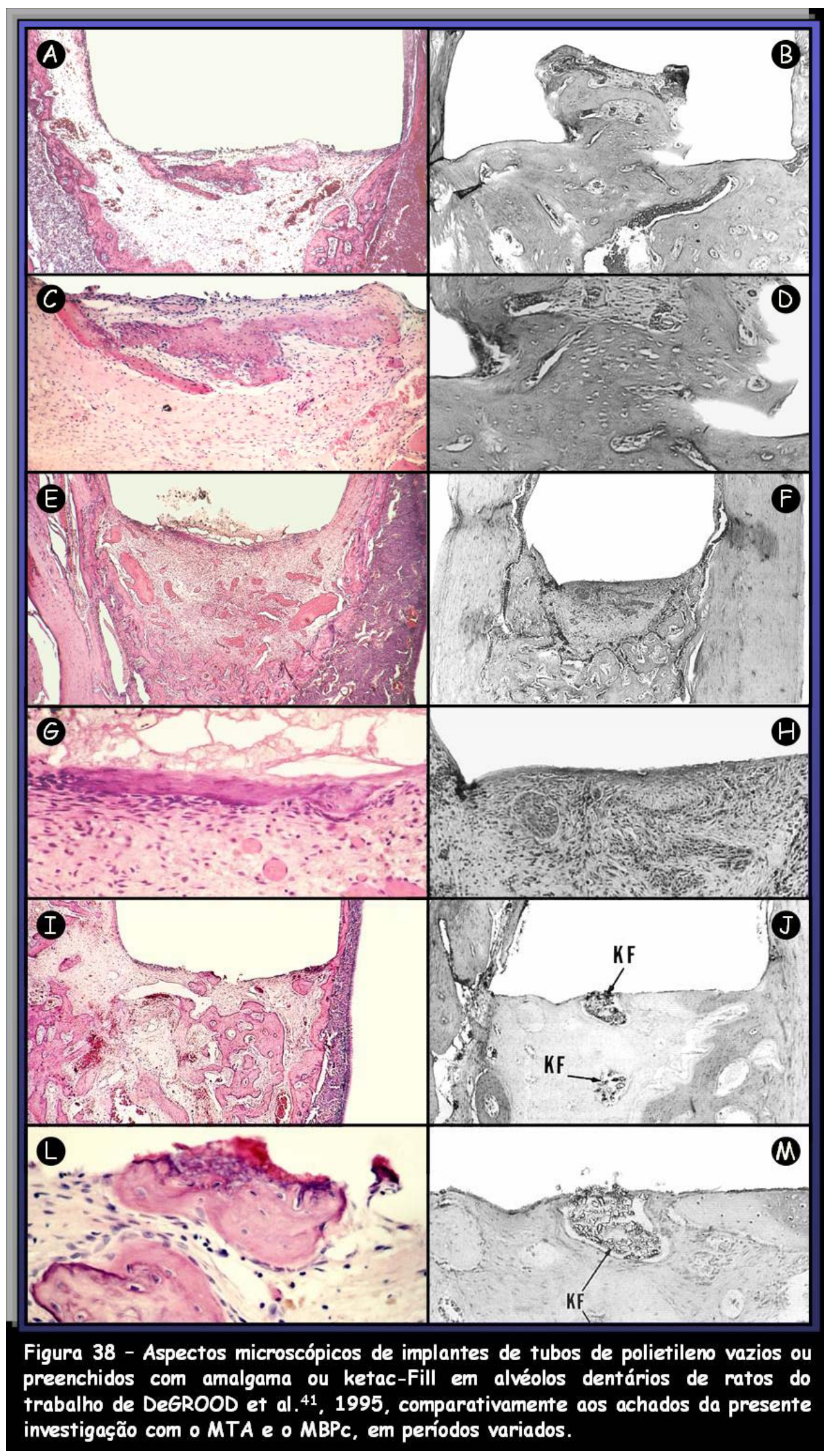




\subsection{APLICAÇÕES CLÍNICO-TERAPÊUTICAS E PERSPECTIVAS}

Os resultados obtidos em várias pesquisas favorecem, definitivamente, o emprego do MTA como material retrobturador. Suas propriedades físicas, químicas e biológicas, tais como vedamento marginal, biocompatibilidade e indução de reparo por deposição de cemento, confirmam a sua aplicabilidade em retrobturações. (TORABINEJAD; WATSON; PITT FORD ${ }^{147}$, 1993; TORABINEJAD et al. ${ }^{137,138,139,140,143}$, 1995; TORABINEJAD et al. $^{142}$, 1997; FISCHER, ARENS, MILLER ${ }^{46}, 1998$; TORABINEJAD, CHIVIAN $\left.{ }^{144}, 1999\right)$.

No tocante às indicações do MTA, TORABINEJAD; CHIVIAN $^{144}$, em 1999, descreveram-nas, destacando os procedimentos clínicos para a aplicação desse material. Segundo os autores, o MTA pode ser empregado com sucesso em casos de capeamento pulpar direto, reparo de perfurações radiculares; como material retrobturador e tampão apical em casos de rizogênese incompleta. Acrescentaram, ainda, a utilização do MTA como tampão cervical em clareamentos dentários internos, material restaurador temporário e para reparar fraturas radiculares verticais.

Quanto às perspectivas para tal produto, acredita-se que estas estão vinculadas ao aperfeiçoamento de algumas características que ainda não estão próximas das ideais. A dificuldade de manipulação, o tempo de presa e a estética, quando em dentes anteriores, podem ser citados como alguns dos problemas relativos ao emprego o MTA. Na tentativa de se solucionar os inconvenientes relativos à presa deste material algumas pesquisas estão sendo desenvolvidas na tentativa de se adicionar aceleradores de presa sem que estes alterem suas propriedades (ABDULL et al. $^{1}$, 2000; BORTOLUZZI; BROON; BRAMANTE ${ }^{25}$, 2004, BROON; BORTOLUZZI; BRAMANTE ${ }^{27}$, 2004). Quanto à possível alteração cromática dos dentes ou mesmo à falta de estética, evidenciada por transparência nos dentes anteriores, recentemente foi lançado no comércio o MTA de cor branca que superou estes inconvenientes. 
Acredita-se, portanto, que o aperfeiçoamento do material é uma questão de tempo.

Quanto ao MBPc, os resultados obtidos em várias pesquisas favorecem o seu emprego como material retrobturador, pois as propriedades, até então avaliadas confirmam sua aplicabilidade (PAVAN ${ }^{101}$, 1999; BRANDÃO ${ }^{26}$, 1999; SILVA NETO; MORAES ${ }^{126}$, 2003; SIQUEIRA ${ }^{127}$, 2004).

Soma-se agora os primeiros resultados de cunho biológico observados com o MBPc que evidenciaram a biocompatibilidade deste material.

No tocante às indicações do MBPc, MORAES e BERBERT, seus idealizadores, descrevem-nas destacando os procedimentos clínicos para os casos de perfurações radiculares ou de furca atuando como selador das comunicações entre o meio interno e externo do dente ou para os casos de cirurgia parendodôntica atuando como material retrobturador.

Também aventam a possibilidade deste material ser empregado com material capeador, como tampão apical em casos de rizogênese incompleta e como tampão cervical em caso de clareamento dentário interno.

Quanto às perspectivas relacionadas a este material, refletese o fato de que, apesar dos bons resultados evidenciados após o emprego do MBPc, deve-se ter a precaução quanto à sua aplicação clínica antes da realização de outras pesquisas. Entretanto, os resultados aqui apresentados são entusiasmadores principalmente quando comparados aos do MTA, material este já consagrado como um dos melhores materiais retrobturadores e seladores de perfurações. 
7 CONCLUSÕES 


\section{CONCLUSÕES}

Levando-se em consideração as condições experimentais em que este trabalho foi realizado, expostas na metodologia empregada, e de acordo como os resultados obtidos, pode-se concluir que:

7.1 Microscopicamente o cimento reparador ProRoot MTA e o cimento experimental MBPc apresentaram resultados gerais semelhantes entre si quanto à reação tecidual frente ao seu emprego;

7.2 Quanto ao critério densidade de fibroblastos jovens, no período de 30 dias, houve diferença significante do ponto de vista estatístico entre os grupos experimentais, com superioridade para o MBPc.

7.3 Quanto ao critério presença e localização da deposição de tecido ósseo, no período de 7 dias, houve diferença significante, do ponto de vista estatístico, entre os grupos controle e experimentais, revelando que o MBPc foi superior; 
ANEXOS 


\section{ANEXOS}

Anexo 1 - Carta de aprovação do comitê de ética e pesquisa animal para o desenvolvimento deste trabalho

Anexo2 - Carta de aprovação da mudança do título do trabalho junto ao Comitê de ética e pesquisa animal

Anexo 3 - Tabela Peso / Dosagem de anestésico e sedativo empregado 

Anexo 2 - Peso / dosagem do anestésico e sedativo empregado

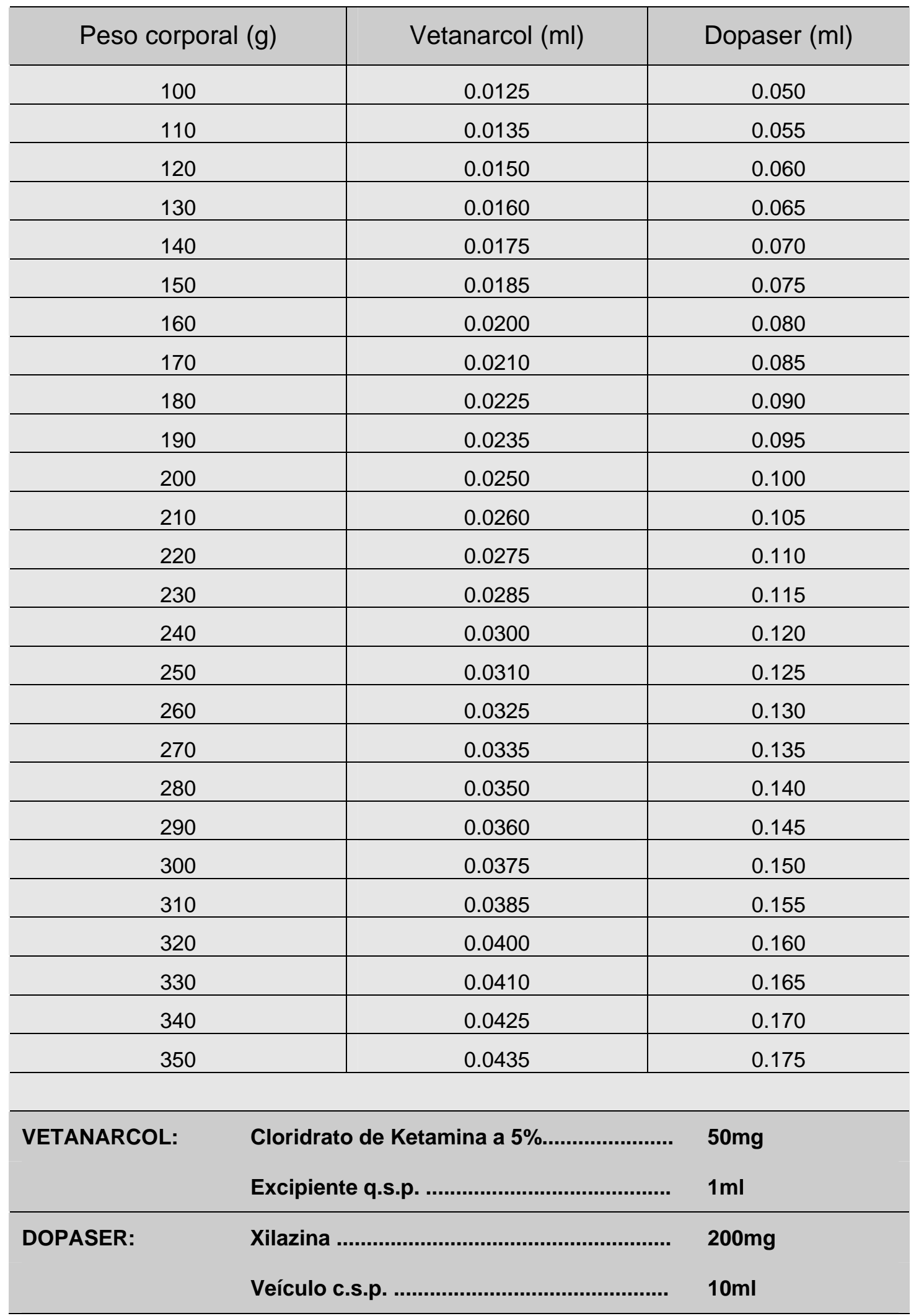




\section{REFERÊNCIAS BIBLIOGRÁFICAS}




\section{REFEREANCIAS BIBLIOGRÁFICAS}

1. ABDULLAH, D. et al. An evaluation of accelerated Portland cement as a restorative material. Biomaterials, v.23, n.19, p.4001-10, Oct. 2000.

2. ADAMO, H.L., et al. A comparision of MTA, Super EBA, composite and amalgam as root-end filling materials using a bacterial microleakage model. Int Endod J, v.32, n.3, p.197-203, May 1999.

3. AEINEHCHI, M.; ESLAMI, B.; GHANBARIHA, M.; SAFFAR, A.S. Mineral trioxide aggregate (MTA) and calcium trioxide as pulpcapping agents in human teeth: a preliminary report. Int Endod J, v.36, n.3, p.225-31, Mar. 2003.

4. AGUIAR, S.A.; SANTOS-PINTO, R.; OKAMOTO, T. Implante de composto para obturações retrogradas em tecido conjuntivo subcutâneo de ratos. Estudo histológico. Rev Ass Paul Cir Dent, v. 35, p. 470-84, 1981.

5. ANDELIN, W.E.; BROWNING, D.F.; HSU, G.H.; ROLAND, D.D.; TORABINEJAD, M. Microleakage of resected MTA. J Endod, v.28, n.8, p.573-4, Aug. 2002.

6. APAYDIN, E.S.; SHABAHANG, S.; TORABINEJAD, M. Hard-tissue healing after application of fresh or set MTA as root-end-filling material. J Endod, v.30, n.1, p.21-4, Jan. 2004.

7. AQRABAWI, J. Sealing ability of amalgam, super EBA cement, and MTA when used as retrograde filling materials. Br Dent J, v.188, n.5, p.266-8, Mar. 2000.

8. ASTRAND, P.; CARLSSON, G.E. Changes in the alveolar process after extractions in the white rat. A histologic and fluorescent microscopic study. Acta Odont Scand, v.27, p.113-127, 1969.

9. BATES, C.F.; CARNES, D.L.; DEL RIO, C.E. Longitudinal sealing ability of mineral trioxide aggregate as a root-end filling material. J Endod, v.22, n.11, p.575-8, Nov. 1996.

10. BERNABÉ, P.F.E. Comportamento dos tecidos periapicais após 
apicectomia e obturação retrógrada. Influência do nível da obturação, do material obturador e das condições do canal radicular: estudo histológico em dentes de cães. Bauru, 1981. 124p. Tese (Doutorado) - Faculdade de Odontologia de Bauru, Universidade de São Paulo.

11. BERNABÉ, P.F.E. Estudo histológico da reação do tecido subcutâneo do rato ao implante de alguns materiais utilizados nas obturações retrógradas dos canais radiculares. São Paulo, 1977, 105p. Dissertação (Mestrado) - Faculdade de Odontologia de São Paulo, Universidade de São Paulo.

12. BERNABÉ, P.F.E. Estudo histopatológico realizado em dentes de cães com lesão periapical após apicectomia e tratamento endodôntico via retrógrada. Influência do nível da obturação e do material obturador. Araçatuba, 1994. 352 p. Tese (Livre-docência) Faculdade de Odontologia de Araçatuba, Universidade Estadual Paulista.

13. BERNABÉ, P.F.E. et al. Avaliação "in vitro" da capacidade seladora marginal e da infiltração na massa de agregados de trióxidos minerais. Braz Oral Res, v.18, p.120, Sept. 2004. IAbstract n. $\mathrm{Pa073/}$

14. BERNABÉ, P.F.E. et al. Avaliação da capacidade seladora de alguns materiais retrobturadores. Robrac, v. 11, n. 32, p. 68-71, 2002.

15. BERNABÉ, P.F.E. et al. Avaliação histopatológica realizada em dentes de cães com lesão periapical após retrobturação com mta e cimento portland. Braz Oral Res, v.18, p.164, Sept. 2004. IAbstract n. $\mathrm{Pb064/}$

16. BERNABÉ, P.F.E. et al. Comparative study of MTA with other materials in retrofilling of pulpless dog's teeth. J Endod, 2002. Ino prelo/

17. BERNABÉ, P.F.E. et al. Evaluation of root end preparations and retrofilling materials in pulpless dog's teeth. J Endod, 2002. /no 
prelo/

18. BERNABÉ, P.F.E. et al. Retrobturação com MTA em dentes de cães: avaliação histopatológica da influência do selamento via coronária. Braz Oral Res, v.18, p.119, Sept. 2004. IAbstract n. $\mathrm{Pa072/}$

19. BERNABÉ, P.F.E. et al. Healing process of root end treatment using ultrasonic instrument and MTA or Portland cement. Int Endod J, 2002. Ino prelo/

20. BERNABÉ, P.F.E. Procedimentos clínicos que podem favorecer a reparação após a realização de cirurgias parendodônticas. In: OPINION MAKERS: Conceitos e procedimentos para uma nova odontologia.. 1ed. São Paulo, VM comunicações Ltda, 2002. Fascículo: Endodontia p. 68-81.

21. BERNABÉ, P.F.E.; HOLLAND, R. Cirurgia parendodôntica: quando indicar e quando realizar. In: GONÇALVES, E.A.N.; FELLER, C. Atualização na Clínica Odontológica. São Paulo, Ed Artes Médicas, 1998. cap.10, p.217-54.

22. BERNABÉ, P.F.E.; HOLLAND, R. MTA e Cimento Portland: Considerações sobre as propriedades físicas, químicas e biológicas. In: CARDOSO, R.J.A.; MACHADO, M.E.L. Odontologia Arte e Conhecimento. São Paulo, Ed Artes Médicas, 2003. v.1, cap. 11, p.225-264.

23. BOHORQUEZ, S.P.; ROCHA, R.S.S.; POSA, O.P.S.; CONSOLARO, A. Avaliação da presença e localização de bactérias nos canais radiculares e nas lesões periapicais crônicas pelo método de Brown \& Brenn. Rev Fac Odontol Bauru, v.3, n.1/4, p.25-31, 1995.

24. BONSON, S.; JEANSONNE, B.G.; LALLIER, T.E. Root-end filling materials alter fibroblast differentiation. J Dent Res, v.83, n.5, p.40813, May 2004

25. BORTOLUZZI, E.A.; BROON, N.J.; BRAMANTE, C.M. Avaliação da capacidade seladora do MTA e cimento portland com ou sem cloreto de cálcio em obturações retrógradas. Braz Oral Res, v.18, p.213, 
Sept. 2004. IAbstract n. Pc082/

26. BRANDÃO, C.G. Propriedades físico-químicas dos cimentos endodônticos resinosos Sealer Plus e MBP, comparadas ás do cimento de óxido de zinco e eugenol. Bauru, 1999. 150 p. Dissertação (Mestrado) - Faculdade de Odontologia de Bauru, Universidade de São Paulo.

27. BROON, N.J.; BORTOLUZZI, E.A.; BRAMANTE, C.M. Análise do pH, liberação de íons de cálcio e tempo de endurecimento do MTA e cimento portland com ou sem cloreto de cálcio. Braz Oral Res, v.18, p.210, Sept. 2004. /Abstract n. Pc063/

28. CAIEDO, R. et al. Sealing capacity of Super EBA, ProRoot MTA, Diaket in the repair of root perforations. J Endodon, v.26, n.9, p.553, 2000. /Abstract n.PR2/

29. CARVALHO, A.C.; OKAMOTO, T. Implantes intra-alveolares. Considerações sobre estudos experimentais. Rev Ass Paul Cir Dent, v.32, n.4, p.273-9, Jul. / Aug. 1978.

30. CARVALHO, A.C.P.; OKAMOTO, T. Interferências sistêmicas sobre o processo de reparo em feridas de extração dental. Rev Odont Unesp, v.14, n.1/2, p.27-33, 1985.

31. CARVALHO, A.C.P.; OKAMOTO, T. Reparaçäo do alvéolo dental. In: CARVALHO, A.C.P.; OKAMOTO, T. Cirurgia Bucal: fundamentos experimentais aplicados à clínica. São Paulo, Panamericana, 1987. p.55-80.

32. CARVALHO, A.C.P.; OKAMOTO, T.; SAAD NETO, M. Reação do tecido subcutâneo a alguns anestésicos locais. Estudo histológico em ratos. Rev Fac Odont Araçatuba, v. 5, p. 53-61, 1976.

33. CASTRO, A.L. et al. Syntetic bone implants following tooth extractions. A histological study in rats. Bull Tokyo Dent Coll, v.11, p.193-9, 1970.

34. COUNCIL ON DENTAL MATERIAL AND DEVICES. American Dental Association. Recomended standard practices for biological evaluation. J Am Dent Assoc, v. 84, n.2, p.382-90, Feb. 1972. 
35. COUNCIL ON DENTAL MATERIALS AND DEVICES. American National Standards Institute / American Dental Association Document no. 41 for Recommended Standard Practices for Biological Evaluation of Dental Materials.. J Am Dent Assoc, v.99, n.4, p.6978, Oct. 1979.

36. CUMMINGS, G.R.; TORABINEJAD, M. Mineral trioxide aggregate (MTA) as na isolating barrier for internal bleaching. J Endod, v.21, n.4, p.228, 1995. /Abstracts n.RS53/.

37. CURY, A. et al. Influência do "alveosan" sobre o processo de reparo perturbado de feridas de extração dental. Estudo histológico em ratos. Rev Odont Unesp, v.12, p.29-35, 1983.

38. DALÇÓQUIO, C. et al. Selamento apical após retrobturaçöes com MTA, IRM, ionômero de vidro e cianoacrilato. Rev Ass Paul Cir Dent, v.55, n.3, p.194-8, 2001.

39. DAOUDI, M.F.; SAUNDERS, W.P. In vitro evaluation of furcal perforation repair using mineral trioxide aggregate or resin modified glass ionomer cement with and without the use of the operating microscope. J Endod, v.28, n.7, p.512-5, Jul. 2002.

40. DEAL, B.F. et al. Chemical and physical properties of MTA, Portland Cement and a new experimental material, fast-set MTA. J Endod, v.28, n.3, p.252, 2002. IAbstracts n.OR70/

41. DeGROOD, M.E. et al. A comparison of tissue reactions to Ketac-Fil and Amalgam. J Endod, v. 21, n. 2, p. 65-9, Feb. 1995.

42. ECONOMIADES, N. et al. Experimental study of the biocompatibility of four root canal sealers and their influence on the zinc and calcium content of several tissues. J Endod, v.21, n.3, p.122-7, Mar. 1995.

43. ECONOMIDES, N.; PANTELIDOU, O.; KOKKAS, A.; TZIAFAS, D. Short-term periradicular tissue response to mineral trioxide aggregate (MTA) as root end filling material. Int Endod, v.36, n.1, p.44-8, Jan. 2003.

44. ESTRELA, C. et al. Antimicrobial and chemical study of MTA, Portland cement, calcium hydroxide paste, Sealapex and Dycal. 
Braz Dent J, v. 11, n. 1, p. 3-9, 2000.

45. FARACO JÚNIOR, I.M.; HOLLAND, R. Response of the pulp of dogs to capping with mineral trioxide aggregate or a calcium hydroxide cement. Dent Traumatol, v.17, n.4, p.163-6, 2001.

46. FISCHER, E.J.; ARENS, D.E.; MILLER, C.H. Bacterial leakage of mineral trioxide aggregate as compared with zinc-free amalgam, intermediate restorative material and Super EBA as a root-end filling material. J Endod, v.24, n.3, p.176-9, Mar. 1998.

47. FORD, T.R. et al. Using mineral trioxide aggregate as a pulpcapping material. J Am Dent Assoc, v.127, n.10, p.1491-4, Oct. 1996.

48. FORD, T.R. et al. Use of mineral trioxide aggregate for repair of furcal perforations. Oral Surg Oral Med Oral Pathol Oral Radiol Endod, v.79, n.6, p.756-63, Jun. 1995.

49. GOMES, A.P.M. et al. Avaliação do selamento de retrobturações realizadas com Super EBA e MTA após preparo cavitário com ultrasom ou brocas. Ciênc Odontol Brás, v.6, n.2, p.20-8, 2003.

50. GONÇALVES, S.B.; BRAMANTE, C.M. Avaliação da capacidade seladora do super EBA e do MTA em quatro técnicas de obturação retrograda. Rev Fac Odontol Bauru, v.10, n.3, p.170-8, 2002.

51. GUTMAN, J.L.; HARRISON, J.W. Surgical endodontics. Boston, Blackwell Scientific, 468p. 1991.

52. GUTUSO, J. Histopatologic study of rat connective tissue response to endodontic material. Oral Surg Oral Med Oral Pathol, v.16, n.6, p.713-27, June 1963.

53. HANKS, et al. Cytotoxic effects of resin components on cultured mammalian fibroblasts. J Dent Res, v.70, n.11, p.1450-5, Nov. 1991.

54. HARTY, F.J.; PARKINS, B.J.; WEINGRAF, A.M. The success rate of apicectomy: retrospective study of 1067 cases. Br Dent J, v.29, p.407-13, 1970.

55. HERZOG-FLORES, D.S. et al. Análisis fisicoquímico del mineral 
trioxido agregado (MTA) por difracción de rayos $\mathrm{X}$, calorimetria e microscopía electrónica de barrido. Rev ADM, v.57, n.4, p.125-31, 2000.

56. HOLLAND, R. Histochemical response of amputed pulps to calcium hydroxide. Rev Bras Pesq Med Biol, v.4, n.1-2, p.83-95, 1971.

57. HOLLAND, R. et al. Agregado de trioxido mineral y cemento Portland em la obturación de conductos radiculares de perro. Endodoncia, v.19, p.275-80, 2001.

58. HOLLAND, R. et al. Healing process of dog dental pulp after pulpotomy and pulp covering with mineral trioxide aggregate or Portland cement. Braz Dent J, v.12, n.2, p.109-13, 2001.

59. HOLLAND, R. et al. Mineral trioxide aggregate repair of lateral roots perforations. J Endod, v.27, n.4, p.281-4, Apr. 2001.

60. HOLLAND, R. et al. Reaction of dogs' teeth to root canal filling with mineral trioxide aggregate or a glass ionomer sealer. J Endod, v.25, n.11, 728-30, Nov. 1999.

61. HOLLAND, R. et al. Reaction of rat connective tissue to implanted dentin tubes filled with a white mineral trioxide aggregate. Braz Dent J, v.13, n.1, p.23-6, 2002.

62. HOLLAND, R. et al. Reaction of rat connective tissue to implanted dentin tubes filled with mineral trioxide aggregate or calcium hydroxide. J Endod, v.25, n.3, p.161-6, 1999.

63. HOLLAND, R. et al. Reaction of rat connective tissue to implanted dentin tube filled with mineral trioxide aggregate, Portland cement or calcium hydroxide. Braz Dent J, v.12, n.1, p.3-8, 2001.

64. HOLLAND, R. et al. Resposta do tecido conjuntivo subcutâneo do rato ao implante de alguns materiais obturadores de canal. Rev Fac Odont Araçatuba, v.2, p.217-25, 1973.

65. HOLLAND, R.; SOUZA, V. Ability of a new calcium hydroxide root canal filling material to induce hard tissue formation. J Endod, v.11, p.535-43, 1985.

66. HONG, C.U.; TORABINEJAD, M.; KETTERING, J.D. The effects of 
three retrofilling materials on selected oral bacteria. J Endod, v.19, n.4, p.200, 1993. /Abstract n.\#67/

67. INTERNATIONAL ORGANIZATION FOR STANDARDIZATION. Dentistry - Preclinical evaluation of biocompatibility of medical devices used in dentistry - Test methods for dental materials. Genève, 1997. 22p. Technical Report 7405.

68. KEISER, K.; JOHNSON, C.C.; TRIPTON, D.A. Citotoxicity of mineral trioxide aggregate using human periodontal ligament fibroblasts. J Endod, v.26, n.5, p.288-91, May. 2000.

69. KETTERING, J.D.; TORABINEJAD, M. Investigation of mutagenicity of mineral trioxide aggregate and other commonly used root-end filling materials. J Endod, v.21, n.11, p.537-9, 1995.

70. $\mathrm{KOH}$, E.T. et al. Mineral trioxide aggregate stimulates a biological response in human osteoblasts. J Biomed Mater Res, v.37, n.3, p.432-439, Dec. 1997.

71. KUTTLER, Y. Fundamentos de endo-metaendodôncia práctica. México,. Mendez Oteo, 2a ed, p. 182, 1980.

72. KWAK, K.I.; PARK, D.S.; OH, T.S. The effect of obturation timing and thickness of mineral aggregate matrix on sealing ability. J Endod, v.26, n.9, p.557, 2000. /Abstract n.PR21/

73. LAMANO CARVALHO, T.; BOMBONATO, K.; BRENTEGANI, L. Histometric analysis of rat alveolar wound healing. Braz Dent J, v.8, n.1, p.9-12, 1997.

74. LANDIS, J.R.; KOCH, G.G. The measurement of observer agreement for categorical data. Biometrics, v.33, n.1, p.159-74, Mar. 1977.

75. LANGELAND, $\mathrm{K}$. et al. Methods in the study of biologic responses to endodontic materials. Oral Sur Oral Med Oral Pathol, v.27, n.4, p.522-42, Apr. 1969.

76. LANGELAND, K.; OLSSON, B.; PASCON,A. Biological evaluation of Hydron. J Endod, v.7, n.5, p.196-204, May. 1981.

77. LANZA, L.D. Avaliação clínica e microscópica de um sistema 
adesivi aplicado em proteções pulpares diretas de dentes humanos. Bauru, 1997. 145p. Tese (Doutorado) - Faculdade de Odontologia de Bauru, Universidade de São Paulo.

78. LEE, S.J.; MONSEF, M.; TORABINEJAD, M. Sealing ability of a mineral trioxide aggregate for repair of lateral root perforations. J Endod, v.19, n.11, p.541-544, 1993.

79. LILLIE, R.D. Histopathologic technique and pratical histochemistry. New York, Blakinston, 2a ed. 501p, 1954.

80. LIN, W.L.; MCCULLOCH, C.A.; CHO, M.I. Differentiation of periodontal ligament fibroblasts into osteoblasts during socket healing after tooth extraction in the rat. Anat Rec, v.240, n.4, p.492506, Dec. 1994.

81. MARCOTTE, L.R.; DOWSON, J.; ROWE, N.H. Apical healing with retrofilling materials amalgam and gutta-percha. J Endod, v.1, n.2, p.63-65, 1975.

82. MARTELL, B.; CHANDLER, N.P. Electrical and dye leakage comparison of MTA, super EBA and IRM. J Endod, v.26, n.9, p.545, 2000. /Abstracts n.OR39/

83. MENEZES, R.; BRAMANTE C.M.; LETRA, A.; CARVALHO, V.G.; GARCIA, R.B. Histologic evaluation of pulpotomies in dog using two types of mineral trioxide aggregate and regular and white Portland cements as wound dressings. Oral Surg Oral Med Oral Pathol Oral Radiol Endod, v.98, n.3, p.376-9, Sep. 2004.

84. MITCHELL, P.J. et al. Osteoblast biocompatibility of mineral trioxide aggregate. Biomat, v.20, n.2, p.167-173, Jan. 1999.

85. MOLLOY, D. et al. Comparative tissue tolerance of a new endodontic sealer. Oral Surg Oral Med Oral Pathol, v.73, n.4, p.490-3, April. 1992.

86. MORAES, I.G. Propriedades físicas de cimentos epóxicos experimentais para obturação de canais radiculares, baseados no AH26. Bauru, 1984. 150p. Tese (Doutorado) - Faculdade de Odontologia de Bauru, Universidade de São Paulo. 
87. MORANDI, R. Avaliação histomorfológica realizada em dentes de cães com lesão periapical, após apicectomia e obturação retrógrada convencional com cimentos a base de óxido de zinco e eugenol e o agregado de trióxido mineral. Araçatuba, 1999, 319p. Dissertação (Mestrado) - Faculdade de Odontologia de Araçatuba -Universidade Estadual Paulista.

88. MORETTON, T.R. et al. Tissue reactions after subcutaneous and introosseous implantation of mineral trioxide aggregate and ethoxybenzoic acid cement. J Biomedic Mater Res, v.52, n.3, p.528-33, 2000.

89. MORSE, D.R. et al. A comparative tissue toxicity evaluation of gutapercha root canal sealers. Part I. six hour findings. J. Endod. v. 10, n.6, p.246-9, Jun. 1984.

90. MORSE, D.R. et al. A comparative tissue toxicity evaluation of the liquid components of guta-percha root canal sealers. J Endod, v.7, n.12, p.545-50, 1981.

91. NAKATA, T.T.; BAE, K.S.; BAUMGARTNER, J.C. Perforation repair comparinf Mineral Trioxide Aggregate and Amalgam using an anaerobic bacterial leakage model. J Endod, v.24, n.3, p.184-6, Mar. 1998.

92. NARY FILHO, H.; OKAMOTO, T. Avaliação da biocompatibilidade de implantes de Hapset em feridas de extração dental. Rev Fac Odont Bauru, v.4, n.1/2, p.55-64, 1996.

93. OKАMOTO, T. Estudo histoquímico da reatividade do tecido conjuntivo alveolar após extrações dentais. Araçatuba, 1964. 53p. Tese (Doutorado) - Faculdade de Odontologia de Araçatuba, Universidade Estadual Paulista.

94. OKAMOTO, $\mathrm{T}$. et al. Implante de boplant em alvéolos dentais. Estudo histológico em ratos. Rev. Fac. Odont. Araçatuba, v. 3, p. 13-21, 1974.

95. ОКАМОТО, T. et al. Interference of the blood clot on granulation tissue formation after tooth extraction. Histomorphological study in 
rats. Braz Dent J, v.5, p.85-92, 1994.

96. OKAMOTO, T.; RUSSO, M.C. Wound healing following tooth extraction. Histochemical study in rats. Rev Fac Odont Araçatuba, v. 2, p. 153-69, 1973.

97. OKAMOTO, T.; SOLER, M.H.; BARROSO, J.S. Implante de esponja de polivinil álcool associada a antibióticos e hemostáticos em alvéolos dentais. Estudo histológico em ratos. Rev Fac Odont Araçatuba, v. 12, p. 21-8, 1983.

98. OLSSON, B. et al. Subcutaneous implantation for the biological evaluation of endodontic materials. J Endod, v.7, n.8, p.355-69, Aug. 1981.

99. ORSTAVIC, K.D.; MIJÖR, I.A. Histopatoloy and x-ray microanalysis of the subcutaneous tissue response to endodontic sealers. J Endod, v.14, n.1, p.13-23, Jan., 1988.

100. OSÓRIO, R.M. Citotoxicity of endodontic materials. J Endod, v.24, n.2, p.91-6, Feb, 1998.

101. PAVAN, N.N.O. Análise da infiltração marginal em obturações retrógradas realizadas com polímero de mamona, epóxico experimental, cimento de óxido de zinco e eugenol reforçado (Super-EBA) e ionômero de vidro (FUJI II LC). Bauru, 1999, 99p. Dissertação (Mestrado) - Faculdade de Odontologia de Bauru, Universidade de São Paulo.

102. PELLICCIONI, G.A. et al. Evaluation of osteoblast-like cell response to Proroot MTA (mineral trioxide aggregate) cement. J Mater Sci Mater Med, v.15, n.2, p.167-73, Feb. 2004.

103. PETERS, C.I.; PETERS, O.A. Occlusal loading of EBA and MTA root-end fillings in a computer-controlled mastigator: a scanning electron microscopic study. Int Endod J, v.35, n.1, p.22-9, Jan. 2002.

104. PHILLIPS, J.M. Rat connective tissue response to hollow polytilene tube implants. J Canad Dent Assoc, v.33, n.2, p.59-64, 1967.

105. PINHEIRO, T.N., ROLDI, A. CONSOLARO, A. Avaliação da 
citotoxicidade ao implante de discos de dentina preenchidos por Agregado de Trióxido Mineral ou Cimento Portland em subcutâneo de ratos. In: JORNADA DE INICIAÇÃO CIENTÍFICA DA UFES, 2002, Anais, Espírito Santo, 2002, v.12. p.59.

106. PITT FORD, T.R. Relation between seal of root fillings and tissue response. Oral Surg Oral Med Oral Pathol, v.55, n.3, p.241-4, Mar. 1983.

107. PITT FORD, T.R.; HONG, C.U.; TORABINEJAD, M. Mineral trioxide aggregate as a root-end filling material. J Endod,v.20, n.4, p.188, 1994. /Abstracts n.RS1/

108. PITT FORD, T.R. et al. Using mineral trioxide aggregate as a pulpcapping material. J Am Dent Assoc, v.127, n.10, p.1491-4, 1996.

109. RATHBUN, M.A. Cytotoxicity of a BIS-GMA dental composite before and after leaching in organic solvents. J Biomed Mater Res, v.25, n.4, p.443-57, Apr. 1991.

110. ROWE, A.H.R. Effect of root filing materials on the periapical tissues. Br Dent J, v.7, p.98-102, Feb. 1967.

111. RUD, J.; ANDREASEN, J.O.; JENSEN, J.E.M. Radiographic criteria for the assessment of healing after endodontic surgery. Int $\mathbf{J}$ Oral Sur, v.1, n.4, p.195-214, 1972.

112. SAAD NETO, M.; CALLESTINI, E.; OKAMOTO, T. Indicações clínicas e perspectivas futuras de substâncias e materiais empregados no alvéolo. Rev Reg Araçatuba, v.8, n.1, p.5-10, 17, 1987.

113. SAAD NETO, M.; CARVALHO, A.P.C.; OKAMOTO, T. Comportamento do processo de reparo em feridas de extração dental após implante de esponja de gelatina. Estudo histológico em ratos. Rev Ass Paul Cir Dent, v.29, p.44-7, 1975.

114. SAAD NETO, M.; CARVALHO, A.P.C.; OKAMOTO, T. Proplast implantation into rat dental socket. Rev Odont Unesp, v.8/9, p.2733, 1979/80.

115. SAFAVI, K.; NICHOLS, F.C. Secretion of PGE2 from monocytos 
exposed to MTA or Portland cement. J Endod, v.26, n.9, p.540, 2000. /Abstract n.OR18/

116. SAFAVI, K.E. et al. An in vitro method for longitudinal evaluation of toxicity of endodontic sealers. J Endod, v.15, n.10, p.484-6, Oct. 1989.

117. SAIDON, J.; SAFAVI, K.; SPANGBERG, L.S. Tissue reaction to implanted Mineral Trioxide Aggregate or Portland cement. J Endod, v.28, n.3, p.247, Mar. 2002. IAbstract n.OR52/

118. SANCHES, M.G., et al. Processo de reparo em feridas de extração dental após implante de "cera óssea". Estudo histológico em ratos. Rev Fac Odont Araçatuba, v.5, p.32-9, 1976

119. SANCHES, M.G., et al. Silicone implantation into dental sockets. Histological study in rats. J Nihon Univ Sch Dent, v.24, p.218, 226, Dec. 1982.

120. SANCHES, M.G.; OKAMOTO, T.; CARVALHO, A.C.P. Silicone implantation into dental sockets. Histological study in rats. Rev Fac Odont Araçatuba, v.1, p.83-90, 1972.

121. SANTOS-PINTO, R. et al. Implants of polyvinyl alcohol sponge (Ivalon) following tooth extractions. A histological study in rats. Oral Surg, v.8, p.36-41, 1969.

122. SASAKI, T.; OKAMOTO, T. Tratamento local de infecções do alvéolo após extração. Rev Bras Odont, v.25, p.82-92, 1968.

123. SCHEERER, S.Q.; STEIMAN, H.R.; COHEN, J.A. Comparative evaluation of three root-end filling materials: an in vitro leakage study using Prevotella nigrescens. J Endod, v.27, n.1, p.40-2, Jan. 2001.

124. SHABAHANG, S. et al. A comparative study of root-end induction using osteogenic protein-1, calcium hydroxide, and mineral trioxide aggregate in dogs. J Endod, v.25, n.1, p.1-5, Jan. 1999.

125. SIEGEL, S. Non-parametric statistic for the behavioral sciences. McGraw-Hill Book Co., N.Y., p.184-94, 1956.

126. SILVA NETO, U.X.; MORAES, I.G. Capacidade seladora proporcionada por alguns materiais quando utilizados em 
perfurações na região de furca de molares humanos extraídos. J Appl Oral Sci, v.11, n.1, p.27-33, 2003.

127. SIQUEIRA, D.C.R. et al. Avaliação da infiltração bacteriana de cimentos utilizados na retrobturação. Braz Oral Res, v.18, p.162, Sept. 2004. /Abstract n. Pb045/

128. SLUYK, S.R.; MOON, P.C.; HARTWELL, G.R. Evaluation of setting properties and retention characteristics of mineral trioxide aggregate when used as a furcation perforation repair material. J Endod, v.24, n.11, p.768-71, 1998.

129. SNIDER, D. et al. Effect of root canal obturation and/or coronal seal on the success of root canal therapy. J Endod, v.25, n.4, p.294, 1999. /Abstracts n.OR50/

130. STANFORD, J.W. Federação Dentária Internacional. Commission on dental materials, instruments, equipament and terapeutics. Recomended standard practices for biological evaluation of dental materials. Int Dent J, v.30, n.2, p.140-88, June 1980.

131. STANFORD, J.W. Recommendations for determining biocompatibility and safety for the clinical use of metals in denttistry. Int Dent J, v.36, p.45-8, 1986.

132. STANLEY, H.R. Biological evaluation of dental materials. Int Dent J, v.42, n.1, p.37-46, 1992.

133. TANG H.M. et al. Endotoxin leakage of four root-end filling materials. J Endod, v.23, n.4, 259, 1997. labstract n.OR42/

134. TANG, H.M.; TORABINEJAD, M.; KETTERING, J.D. Leakage evaluation of root-end filling materials using endotoxin. J Endod, v.28, n.1n p.5-7, Jan. 2002.

135. TANOMARU FILHO, M. et al. Capacidade seladora de materiais utilizados em perfuraçöes radiculares laterais. Rev Fac Odontol Lins, v.14, n.1, p.40-3, 2002.

136. TANOMARU, FILHO, $\mathrm{M}$, et al. Capacidade de selamento de materiais retrobturadores em perfurações radiculares lateriais. Rev Bras Odontol, v.59, n.2, p.80-2, 2002 
137. TORABINEJAD $\mathrm{M}$, et al. Bacterial leakage of a mineral trioxide aggregate as a root-end filling material. J Endod, v.21, n.3, p.10912, 1995.

138. TORABINEJAD M, et al. Citotoxicity of four root end filling materials. J Endod, v.21, n.10, p.489-92, 1995.

139. TORABINEJAD, M. et al. Antibacterial effects of some root end filling materials. J Endod, v.21, n.8, p.403-6, Aug. 1995.

140. TORABINEJAD, M. et al. Comparative investigation of marginal adaptation of mineral trioxide aggregate and other commonly used root-end filling materials. J Endod, v.21, n.6, p.295-9, Jun. 1995.

141. TORABINEJAD, $M$. et al. Dye leakage of four root-end filling materials: effects of blood contamination. J Endod, v.20, n.4, p.159163, 1994.

142. TORABINEJAD, M. et al. Histologic assessment of mineral trioxide aggregate as a root-end filling in monkeys. J Endod, v.23, n.4, p.225-8, 1997.

143. TORABINEJAD, M. et al. Investigation of mineral trioxide aggregate for root-end filling in dogs. J Endod, v.21, n.12, p.603-8, Dec. 1995.

144. TORABINEJAD, M.; CHIVIAN, N. Clinical applications of mineral trioxide aggregate. J Endod, v.25, n.3, p.197-205, Mar. 1999.

145. TORABINEJAD, M.; MacDONALD, F.; PITT FORD, T.R. Physical and chemical properties of a new root-end filling material. J Endod, v.21, p.349-353, 1995.

146. TORABINEJAD, M. et al. Tissue reaction to implanted root-end filling materials in the tibia and mandible of guinea pigs. J Endod, v.24, n.7, p.468-71, Jul. 1998.

147. TORABINEJAD, M.; WATSON, T.F.; PITT FORD, T.R. Sealing ability of a mineral trioxide aggregate when used as a root-end filling material. J Endod, v.19, n.12, p.591-595, 1993.

148. TORNEC, C.D. Reaction of rat connective tissue to polyethylene tube implants. Oral Surg Oral Med Oral Pathol, v.21, n.3, p.379-87, Mar. 1966. 
149. TORNEC, C.D. Reaction of rat connective tissue to polyethylene tube implants. Oral Surg Oral Med Oral Pathol, v.24, n.5, p.674-83, Nov. 1967.

150. TROWBRIDGE, H.O.; EMLING, R.C. Inflamação: uma revisão do processo. 4.ed., São Paulo, Quintessence, 1996. 174p .

151. TZIAFAS, D. The dentinogenic effect of mineral trioxide aggregate (MTA) in short-term capping experiments. Int Endod J, v.35, n.3, p.245-54, Mar. 2002.

152. VALERA, M.C. Estudo da compatibilidade biológica de alguns cimentos endodônticos à base de hidróxido de cálcio e um cimento de ionômero de vidro. Avaliação do selamento marginal apical e análise morfológica por microscopia de força atômica. Araraquara, 1995. 332 p. Tese (Doutorado) Faculdade de Odontologia, Universidade Estadual Paulista.

153. VITOR, J.O. et al. Implante de gesso de paris em alvéolos dentais. Estudo histológico em ratos. Rev Fac Odont Araçatuba, v.4, p.719, 1975.

154. WELDON, J.K. et al. Sealing ability of mineral trioxide aggregate and Super EBA when used as furcation repair materials: a longitudinal study. J Endod, v.28, n.6, p.467-70, Jun. 2002.

155. WU, M.K. et al. Long-term seal provided by some root-end filling materials. J Endod, v.24, n.8, p.557-60, 1998.

156. WUCHERPFENING, A.L.; GREEN, D.B. Mineral Trioxide vs Portland cement: two biocompatible filling materials. J Endod, v.25, n.4, p.308, 1999. /Abstract n.XX/

157. YALTIRIK, M. Reactions of connective tissue to mineral trioxide aggregate and amalgam. J Endod, v.30, n.2, p.95-9, Feb. 2004.

158. YATSUSHIRO, J.D. et al. Longitudinal study of the microleakage of two root-end filling materials using a fluid conductive system. J Endod, v.24, n.11, p.716-9, 1998.

159. ZHU, Q. Adhesion of human osteoblasts on root-end filling materials. J Endod, v.26, n.7, p.404-6, 2000. 
ABSTRACT 


\title{
ABSTRACT
}

\author{
EVALUATION OF THE TISSUE RESPONSE TO MTA AND MBPC. \\ MICROSCOPIC ANALISIS OF IMPLANTS IN ALVEOLAR BONE OF RATS.
}

The aim of this work was to evaluate in a quantitative and qualitative manner the inflammatory response and the bone formation after the implantation of tubes filled with the experimental sealer, MBPc, which has calcium hidroxide and was developed by Professors Moraes and Berbert (Endodontic Department - Bauru Dentistry College - USP) comparatively to ProRoot MTA. It was used 48 rats, which were divided in three groups. In the group I, empty polietilene tubes were inserted into the alveolar bone imediatelly after extraction, which were used as control. In the group II and group III, polietilene tubes filled with ProRoot MTA and MBPc were implanted respectivelly. After 7, 15 and 30 days after the implantation, the animals were sacrificed and the right hemi-maxilas, which had the alveolar bone with the tubes implanted, were removed and prepared for ligth microscopic analisis. The results showed that both materials had similar biological response. The scores obtained and submitted to Mann-Whitney statistical test (5\%) did not showed significant differences between the materials. 